Universidade de São Paulo

Faculdade de Educação

ANA PAULA COSTA

Mulheres e professoras em formação:

relatos oferecidos durante um dos cursos de

Gênero e Diversidade na Escola (GDE) 


\title{
Mulheres e professoras em formação: relatos oferecidos durante um dos cursos de Gênero e Diversidade na Escola (GDE)
}

\author{
(versão corrigida) \\ Tese apresentada ao Programa de Pós-Graduação em \\ Educação da Faculdade de Educação da Universidade de \\ São Paulo para obtenção do título de Doutora em \\ Educação. \\ Área de concentração: Educação e Ciências Sociais: \\ Desigualdades e Diferenças \\ Orientadora: Profa. Dra. Cláudia Pereira Vianna
}


AUTORIZO A REPRODUÇÃO E DIVULGAÇÃO TOTAL OU PARCIAL DESTE TRABALHO, POR QUALQUER MEIO CONVENCIONAL OU ELETRÔNICO, PARA FINS DE ESTUDO E PESQUISA, DESDE QUE CITADA A FONTE.

Catalogação na Publicação

Serviço de Biblioteca e Documentação

Faculdade de Educação da Universidade de São Paulo

\section{$37.047 \quad$ Costa, Ana Paula}

C837m Mulheres e professoras em formação: relatos oferecidos durante um dos cursos de Gênero e Diversidade na Escola (GDE) / Ana Paula Costa; orientação Cláudia Pereira Vianna. São Paulo: s.n., 2017. 174 p.; anexos; apêndice

Tese (Doutorado - Programa de Pós-Graduação em Educação. Área de Concentração: Educação e Ciências Sociais: desigualdades e diferenças) - - Faculdade de Educação da Universidade de São Paulo.

1. Sexualidade 2. Relações de gênero 3. Professores 4. Desenvolvimento profissional I. Vianna, Cláudia Pereira, orient. 


\section{FOLHA DE APROVAÇÃO}

Costa, Ana Paula. Mulheres e professoras em formação: relatos oferecidos durante um dos cursos de Gênero e Diversidade na Escola (GDE). 2017. 174 f. Tese (Doutorado em Educação) - Faculdade de Educação, Universidade de São Paulo, São Paulo, 2017.

Tese apresentada ao Programa de Pós-Graduação em Educação da Faculdade de Educação da Universidade de São Paulo para obtenção do título de Doutora em Educação.

Área de concentração: Educação e Ciências Sociais: Desigualdades e Diferenças

Orientadora: Profa. Dra. Cláudia Pereira Vianna

Aprovada em:08/12/2017

Banca examinadora:

Profa. Dra: Cláudia Vianna Pereira.

Instituição: Universidade de São Paulo (USP).

Julgamento: Aprovada.

Profa. Dra: Denise Trento Rebello de Souza.

Instituição: Universidade de São Paulo (USP).

Julgamento: Aprovada.

Profa. Dra: Célia Regina Rossi.

Instituição: Universidade Estadual Paulista (UNESP).

Julgamento: Aprovada.

Profa. Dra: Sandra Gouretti Unbehaum.

Instituição: Fundação Carlos Chagas (FCC).

Julgamento: Aprovada.

Profa. Dra: Inês Assunção de Castro Teixeira.

Instituição: Universidade Federal de Minas Gerais (UFMG).

Julgamento: Aprovada. 
À Ana Laura, que chegou durante o processo de escrita desta tese, trazendo força, alegrias, amor e doçura à minha vida. 


\section{AGRADECIMENTOS}

Quando adentrei pela primeira vez uma escola, descobri que ali era meu lugar. Eu adoro o ambiente escolar, gosto de estudar, de aprender, de ler e de escrever. Certa vez, quando tinha 8 anos, perguntei à professora da $2^{\text {a }}$ série do Ensino Fundamental como eu faria se, após ter terminado o ciclo obrigatório de escolaridade, quisesse continuar meus estudos. Assombrava-me a ideia de a escola ter um término e, consequentemente, eu ter que parar de estudar. A professora riu, mas disse que eu poderia continuar estudando pelo resto da minha vida, se quisesse. Foi assim que me tornei professora e foi também assim que cheguei ao doutorado em Educação.

Apesar do meu imenso prazer em estudar, experimentei e entendi o quanto dedicar-se à escrita de uma tese é um trabalho árduo e solitário. Vive-se e pensa-se na tese. Em contrapartida, como processo inerente à vida, o tempo não para, e junto a ele acontecem várias coisas (boas e ruins!). Se não fossem certas pessoas, eu não teria conseguido chegar ao fim desta tão importante e sonhada etapa da minha vida.

Muitas pessoas foram fundamentais para o meu crescimento acadêmico: algumas contribuíram de forma direta na pesquisa e na escrita, enquanto outras, embora não tenham estado presentes academicamente, também auxiliaram neste trabalho, ora cuidando de mim, ora estando ao meu lado. A todos(as) vocês, sou muito grata!

Começo agradecendo à minha orientadora, professora e amiga Cláudia Vianna, por todo apoio e pela aprendizagem que me possibilitou. Você se tornou uma referência de mulher, professora e pesquisadora para mim. Assim, agradeço o afeto, a confiança, a paciência e o companheirismo desde o meu ingresso ao doutorado. Meu carinho e minha admiração por você, certamente, são eternos!

Ao grupo de Estudos de Gênero, Educação e Cultura Sexual (EdGES), coordenado pelas professoras Cláudia Vianna e Marília Carvalho, agradeço a generosidade em me receber e em me propiciar tantos conhecimentos, em especial, os adquiridos durante os encontros de orientação coletiva com orientandos(as) da professora Cláudia, toda a minha gratidão pelas leituras, experiências, angústias e aflições compartilhadas. Agradeço à Bete, ao Paulinho, à Tati, ao Alexandre, à Natália, à Carol, à Neide, à Thais, à Edna, à Raquel e à Sandra as contribuições que tiveram 
início quando esta tese ainda era um projeto. Ao Osmar, sou grata por ter intermediado minha apresentação à Cláudia; ao Hamilton, pelo ombro amigo, sempre disposto a me ouvir e a puxar minha orelha quando preciso.

Agradeço às professoras Elba Siqueira de Sá Barreto, Cláudia Valentina Assumpção Galian, Adriana Bauer e Belmira A. de Barros Oliveira Bueno as reflexões e os conhecimentos compartilhados durante as disciplinas cursadas no ano de 2013. Em especial, agradeço à professora Marília Sposito a leitura crítica de meu projeto de pesquisa.

À professora Célia Rossi, da UNESP de Rio Claro, agradeço a amizade e as oportunidades, fundamentais para que eu chegasse até aqui: foi ela a responsável por me apresentar à minha orientadora e também pela minha participação no curso Gênero e Diversidade na Escola como tutora a distância. Agradeço à Fabiana, por ter me cedido dados acerca da edição de 2009 do curso; à Adriana, que trabalhou comigo como tutora presencial e em 2014 facilitou meu contato com as professoras de São José do Rio Preto (SP); e à Anne, que, sendo minha parceira como tutora presencial, em muito me auxiliou na coleta dos dados da plataforma Moodle.

Agradeço às seis professoras que gentilmente participaram desta pesquisa. Eu estava no quinto mês de gestação quando viajei a SJRP para entrevistá-las. Por estar grávida e longe de casa, cheguei à cidade um pouco receosa, com medo de algo dar errado. No entanto, o medo logo foi passando, já que fui muito bem acolhida por essas mulheres. Foram manhãs e tardes agradáveis ao lado delas, de muita conversa e de muita aprendizagem. Desse modo, agradeço toda a preocupação, a atenção e a confiança em mim e em meu trabalho.

Às professoras Edla Eggert e Denise Trento Rebello de Souza, agradeço a leitura crítica de meu relatório de qualificação. As sugestões propostas por vocês deram um norte à minha escrita e se tornaram valiosas contribuições para a pesquisa.

À minha amiga Erotides, agradeço a revisão da primeira escrita deste texto, quando ele ainda era um relatório de qualificação. À Elisa, a leitura cuidadosa da versão que, enfim, transformou-se nesta tese. 
Minha gratidão aos(às) alunos(as), aos(às) funcionários(as) e aos(às) professores(as) da escola estadual em que leciono, Prof. Ary Menegatto. Agradeço à minha diretora Marinilse toda a compreensão em ajustar meus horários de aula conforme minhas necessidades de mãe, professora e pesquisadora. À Mara, à Eleni, à Ângela, à Vanessa, à Zapia, à Rita, à Solange e ao Bado, agradeço a amizade e a cumplicidade. Ao Edgard, as entusiasmadas conversas feministas.

Agradeço às minhas tias Liza e Bibiana, por nunca me negarem nenhum tipo de ajuda, seja com os serviços domésticos de minha casa, seja com o cuidado de minha filha e de meus pais durante minha ausência. Todo o esforço de vocês contribuiu para que eu tivesse mais tempo para estudar.

Aos meus sogros, Senhor Zé e Dona Rosa, agradeço por terem me recebido em suas vidas como uma filha. Muito obrigada por cuidarem da Ana Laura, de maneira tão especial, quando eu estava cansada, quando precisei trabalhar ou, então, quando tive que me dedicar à escrita desta tese.

Agradeço à minha família o apoio incondicional em todas as decisões que tomei até hoje em minha vida. Toda minha gratidão ao meu irmão, meu grande confidente; ao meu pai Vanderlei, que até quando sua saúde permitiu esteve ao meu lado naquilo que mais gosto de fazer: estudar; e à minha mãe Sueli, minha referência de força, coragem, amor e mulher. Obrigada, Teko, mãe e pai, por cuidarem de mim e por ajudarem no cuidado da minha filha. A vocês devo tudo o que sou!

Toda minha gratidão ao meu companheiro, parceiro e marido Marcos, que não mediu nenhum tipo de esforço para me ajudar desde quando eu ainda cogitava prestar o processo seletivo para o doutorado. Muito obrigada por compartilhar comigo o amor e o cuidado da nossa filha, e por literalmente ser meus olhos quando não posso enxergar.

À minha filha Ana Laura, agradeço por ter aparecido (tão inesperadamente!) em minha vida e por ter dado todo um colorido a ela. Todos os dias você me ensina a ser uma pessoa melhor e a não deixar de acreditar em uma sociedade mais justa para nós, mulheres. Espero que um dia você possa ler este trabalho e entender minha luta e meu esforço por um mundo melhor.

Com toda minha força, enfim, muito obrigada a todos(as)! 
O que verdadeiramente somos é aquilo que o impossível cria em nós.

CLARICE LISPECTOR

(A maçã no escuro) 


\section{RESUMO}

COSTA, Ana Paula. Mulheres e professoras em formação: relatos oferecidos durante um dos cursos de Gênero e Diversidade na Escola (GDE). 2017. 174 f. Tese (Doutorado em Educação) - Faculdade de Educação, Universidade de São Paulo, São Paulo, 2017.

O objetivo desta tese foi investigar as possíveis influências do curso semipresencial Gênero e Diversidade na Escola (GDE) na compreensão de seis professoras de Ensino Fundamental da rede municipal de São José do Rio Preto (SP) sobre os significados do que pode está associado às diferentes formas de ser mulher e ser professora, sob a ótica das relações de gênero. Com ênfase na formação docente e na promoção de uma política de educação para a diversidade, o referido curso foi ofertado em 2009 pela Universidade Estadual Paulista "Júlio de Mesquita Filho" (UNESP), campus de Rio Claro. De abordagem qualitativa, a pesquisa utilizou os seguintes instrumentos metodológicos: 1) análise do registro das atividades efetuadas pelas professoras durante o curso; 2) realização e análise de entrevistas semiestruturadas, aplicadas em junho de 2014, com as professoras. A partir do exame do material obtido e tendo em vista as teorizações de Michel Foucault e dos Estudos Feministas, foi possível notar um movimento de reprodução e, ao mesmo tempo, de resistência a regras e discursos engendrados pela sociedade patriarcal a respeito das diferentes formas de ser mulher e ser professora. De modo geral, para essas professoras, o GDE se apresentou como um curso inovador, pois as fez estranhar, questionar e confrontar a visão essencialista que possuíam sobre a sexualidade e as relações de gênero. Todavia, as participantes relatam vários obstáculos - tanto em suas vidas pessoais quanto no âmbito escolar - que dificultam a efetivação do que aprenderam durante o curso. Tais obstáculos demonstram a força dos processos de socialização, bem como alguns aspectos que ainda precisam ser pensados e revisados em relação aos cursos que visam auxiliar o(a) professor(a) ao longo de seu desenvolvimento profissional docente.

Palavras-chave: Sexualidade. Relações de gênero. Desenvolvimento profissional docente. GDE. 


\begin{abstract}
COSTA, Ana Paula. Women and teachers undergoing formation: reports given during the course Gender and Diversity at School (GDE). 2017. $174 \mathrm{f}$. Tese (Doutorado em Educação) - Faculdade de Educação, Universidade de São Paulo, São Paulo, 2017.

The purpose of this thesis was to investigate possible influences of the blended learning course Gender and Diversity at School on the understanding of six Elementary School teachers of São José do Rio Preto (SP) about what it means to be woman and to be teacher, under the perspective of gender relations. By focusing on teacher formation and the promotion of a policy of education for diversity, the above mentioned course was held on 2009 by Universidade Estadual Paulista "Júlio de Mesquita Filho" (UNESP), Rio Claro campus. Based on qualitative approach, the research used the following methodological tools: 1) analysis of the activities undertaken by the teachers during the course; 2) conducting and analyzing semistructured interviews with the teachers. Based on the material collected, and according to Michel Foucault's theorizations as well as Feminist Studies, it was possible to notice a movement of reproduction and, at the same time, of resistance to rules and discourses engendered by patriarchal society about what is to be woman and to be teacher. Broadly speaking, for these teachers, the course presented itself as an innovative opportunity, stimulating them to deconstruct, question and confront their own essentialist views on sexuality and gender relations. Nonetheless, the course participants report several barriers - both in their personal lives and in the school scope - that make it difficult to put into practice what they learned during the course. Such barriers demonstrate the power of socialization processes, as well as some aspects that still need to be analyzed and reconsidered in relation to the courses which aim to assist teachers along their professional development.
\end{abstract}

Keywords: Sexuality. Gender relations. Teacher professional development. Course Gender and Diversity at School. 


\section{LISTA DE SIGLAS}

AVA Ambiente Virtual de Aprendizagem

CEFAM Centro Específico de Aperfeiçoamento e Formação para o Magistério

CEPAL Comissão Econômica para a América Latina e o Caribe

CLAM Centro Latino Americano em Sexualidade e Direitos Humanos

CRAM Centro de Referência de Atendimento à Mulher

EaD Educação a Distância

FAPESP Fundação de Amparo a Pesquisa do Estado de São Paulo

FCAV Fundação Carlos Alberto Vanzolini

FCLAR Faculdade de Ciências e Letras de Araraquara

FDE Fundação para o Desenvolvimento da Educação

FEUSP Faculdade de Educação da Universidade de São Paulo

GDE Gênero e Diversidade na Escola

GSEX Grupo de Pesquisa e Extensão sobre Sexualidade

IBGE Instituto Brasileiro de Geografia e Estatística

LDB Lei de Diretrizes e Bases da Educação Nacional

LGBT Lésbicas, Gays, Bissexuais, Travestis e Transexuais

MEC Ministério da Educação

NUSEX Núcleo de Estudos da Sexualidade

ONG Organização não Governamental

PCN Parâmetros Curriculares Nacionais

PEC Programa de Educação Continuada

PNE Plano Nacional de Educação

PUC Pontifícia Universidade Católica

SECAD Secretaria de Educação Continuada, Alfabetização, Diversidade

SECADI Secretaria de Educação Continuada, Alfabetização, Diversidade e Inclusão

SECRIE Secretaria de Inclusão Educacional

SEDH Secretaria Especial de Direitos Humanos 
SEEA Secretaria Extraordinária de Erradicação do AnalfabetismoSEED Secretaria de Educação a Distância

SENAI Serviço Nacional de Aprendizagem Industrial

SEPPIR Secretaria Especial de Políticas de Promoção da Igualdade Racial

SESI Serviço Social da Indústria

SJRP São José do Rio Preto

SNJ Secretaria Nacional da Juventude

SPM Secretaria de Políticas para as Mulheres

TIC Tecnologia da Informação e Comunicação

UAB Universidade Aberta do Brasil

UERJ Universidade do Estado do Rio de Janeiro

UNDIME União Nacional dos Dirigentes de Ensino

UNESCO Organização das Nações Unidas para a Educação, a Ciência e a Cultura

UNESP Universidade Estadual Paulista "Júlio de Mesquita Filho"

USP Universidade de São Paulo 


\section{SUMÁRIO}

INTRODUÇÃO: DA TRAJETÓRIA PESSOAL À TRAJETORIA ACADÊMICA

1. SEXUALIDADE, RELAÇÕES DE GÊNERO E EDUCAÇÃO: INTERSEÇÕES COM O CURSO GÊNERO E DIVERSIDADE NA ESCOLA (GDE)

1.1 Sexualidade e relações de gênero ...........................................................23

1.2. Sexualidade, relações de gênero e educação .............................................. 31

1.3 Desenvolvimento profissional docente e o curso Gênero e Diversidade

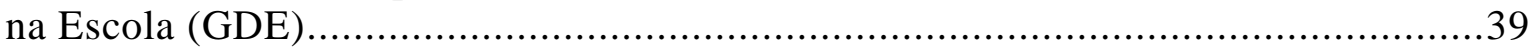

1.4 O curso Gênero e Diversidade na Escola (GDE) da UNESP de Rio Claro............51

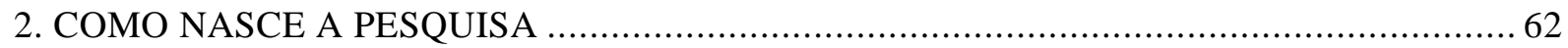

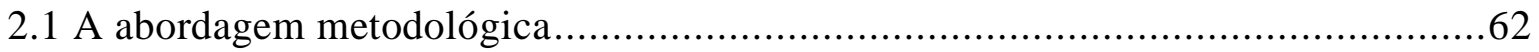

2.2 As mulheres-professoras e a cidade de São José do Rio Preto (SP)....................64

2.3 Os instrumentos de coleta de dados ......................................................66

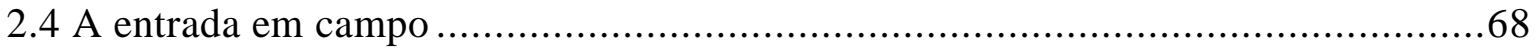

2.5 A forma de análise dos resultados ......................................................... 71

3. AS MULHERES-PROFESSORAS E UM CURSO …................................................ 74

3.1 Gislaine: "Eu acho que ser mulher é representar o belo" ..............................75

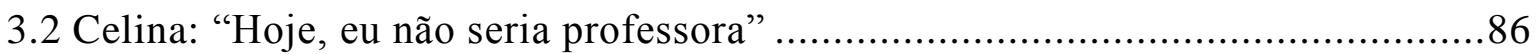

3.3 Helena: "Eu falo que na próxima encarnação eu quero ser homem..." ...............97

3.4 Bianca: “[...] ser professora... Eu penso: 'sou eu', 'esta sou eu'” ...................107

3.5 Carla: "Confesso que tenho muita dificuldade em me relacionar com pessoas

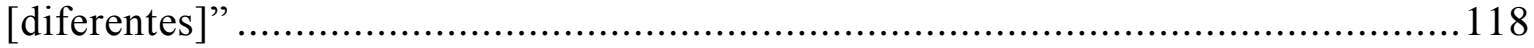

3.6 Maria Rita: "Você quer ter um filho homossexual? Se a pessoa falar 'quero', é mentira"

CONSIDERAÇÕES FINAIS: O GDE, AS MULHERES-PROFESSORAS, OS LIMITES

E AS POSSIBILIDADES.

REFERÊNCIAS .

APÊNDICES 


\title{
INTRODUÇÃO: DA TRAJETÓRIA PESSOAL À TRAJETORIA ACADÊMICA
}

\author{
Era uma vez uma mulher \\ Que via um futuro grandioso \\ Para cada homem que a tocava. \\ Um dia ela se tocou \\ ALICE RUIZ \\ (Ladainha)
}

Meu interesse e minha curiosidade pelas questões de gênero e sexualidade vêm da experiência, da atuação e da luta como mulher na sociedade. Nasci na cidade de Americana (SP) em uma família conservadora e católica, com forte traço patriarcal e uma mãe dona de casa. Tenho um irmão cinco anos mais novo que eu, e embora ele seja o caçula da família, a preocupação de meus pais com a filha mulher era evidente.

Cresci ouvindo, de meu pai, que "Menino brinca com menino, menina brinca com menina"; "Sente direito, feche a perna!"; "É feio gente oferecida!"; "Cuide de seu irmão!"; entre outros chavões machistas que conhecemos. Na época eu acatava, mas, conforme fui crescendo, senti-me no direito de questionar.

Em 1997, aos 15 anos e já morando na cidade de Franca (SP) em consequência do emprego de meu pai, ingressei no curso de magistério pelo Centro Específico de Aperfeiçoamento e Formação para o Magistério, o antigo CEFAM. Arrisco-me a dizer que ali teve início minha independência em relação aos meus pais, afinal a escola era longe de casa, eu estudava em período integral e recebia uma bolsa de estudos. ${ }^{1}$

Estudar no CEFAM permitiu-me aprender desde a andar de ônibus - algo que eu desconhecia, pois meu pai sempre me levava de carro para onde eu quisesse - até a pensar diferente do que eu sempre havia aprendido dentro de casa. Naquele período, por meio de um professor de História, o Bill, ouvi pela primeira vez sobre Karl Marx, alienação, mais-valia, socialismo, comunismo, capitalismo e religião, entre outros

\footnotetext{
${ }^{1} \mathrm{O}$ curso tinha duração de quatro anos, funcionava em período integral e oferecia aos(às) seus(suas) alunos(as) uma bolsa de estudos no valor de um salário mínimo. Em São Paulo, o CEFAM foi criado pelo então governador Orestes Quércia em 1988, tendo sido extinto em 2005. Suas unidades eram distribuídas pelos municípios do Estado de São Paulo.
} 
assuntos. Foi justamente esse professor que me inspirou a ingressar, mais tarde, no curso de Ciências Sociais.

Aprender a desconfiar e a estranhar o mundo em que vivia possibilitou-me, ainda no CEFAM, conhecer algumas ideias feministas. Certa vez, em uma tarde na biblioteca da escola, no terceiro ano, deparei-me com um livro cujo título me chamou a atenção: Homem \& mulher: o mito da desigualdade, de Dulce Whitaker (1988). Não hesitei em lê-lo, ficando incrivelmente extasiada: ao questionar, de forma didática, os estereótipos atribuídos ao feminino e ao masculino, a autora expunha justamente aquilo que eu pensava, mas que, no entanto, pela minha imaturidade, ainda não conseguia formular em palavras. Na sequência, li De Mariazinha a Maria, de Marta Suplicy (1985), livro que evidencia as barreiras sociais enfrentadas pela mulher para se tornar um sujeito autônomo. Essas leituras fizeram-me suspeitar do que até então a mim se apresentava como natural e normal em relação às diferentes formas de ser mulher e de ser homem.

Certa vez, por exemplo, devido a questões estéticas e, sobretudo, de saúde, emagreci oito quilos e uma garota da escola conjecturou que eu certamente havia emagrecido porque tinha arrumado um namorado. Respondi que não estava namorando e que não precisava de um homem para revigorar minha autoestima, afinal não estava me sentindo bem e isso já era suficiente para querer mudar meu corpo. Outra situação marcante ocorreu quando a diretora da escola deu-nos uma bronca, pois as meninas do CEFAM não haviam se comportado bem no centro da cidade: toda vez que recebíamos a bolsa, o colégio nos dispensava para descontarmos o cheque no período da tarde, quando íamos todas ao banco e depois ao centro comercial para comprar alguma coisa; porém, a algazarra das moças e a reclamação dos(as) lojistas à diretora da escola levou a docente a não mais permitir nossa saída à tarde uma vez por mês, já que seríamos futuras professoras do ensino fundamental e a conduta esperada das normalistas era discrição.

Em 2000, último ano do magistério, comecei a frequentar, no período da noite, o cursinho da Universidade Estadual Paulista (UNESP) de Franca destinado a alunos(as) carentes. Meu intuito era prestar vestibular para o curso de Ciências Sociais. Eu estava indo relativamente bem nos estudos quando um professor de redação, estudante do curso de bacharelado em Direito, pediu que desenvolvêssemos parágrafos sobre diversos temas expostos em suas aulas, entre quais se encontrava a questão da 
homossexualidade. Ao escrever o texto, meus argumentos giraram em torno de alguns questionamentos, tais como: "Quem e quando se estipulou que os relacionamentos sexuais deveriam ser somente entre um homem e uma mulher?"; "Por que não conseguimos admitir as outras formas de se amar?”. Eu procurava responder àquelas questões enfatizando o peso da sociedade na vida das pessoas.

Ao ler o texto, o professor rabiscou todo o parágrafo com sua caneta vermelha e disse para mim e toda a sala, em alto e bom som, que argumentos como aqueles certamente nos fariam reprovar na redação do vestibular, uma vez que se tratava de uma questão biológica e não social. "Mas como você quer mudar a natureza?”, gritou ele. Eu me calei, senti-me chateada por ter pensado tamanha besteira, parei de frequentar as aulas de redação e também de questionar as questões de gênero e de sexualidade.

Mesmo não participando das aulas de redação, em 2001 felizmente consegui ingressar no curso de Ciências Sociais da UNESP de Araraquara, município de famílias tradicionais e conservadoras, mas que cheira a feminismo; cidade de Heleieth Saffioti, grande socióloga, ex-professora da Faculdade de Ciências e Letras (FCLAR) da mesma universidade e precursora do feminismo no Brasil; local onde mora e em que lecionou na Dulce Whitaker, autora da minha primeira leitura feminista, quando eu ainda estudava no CEFAM.

Foi em Araraquara que entrei em contato com as questões de gênero e, consequentemente, com o feminismo. Na UNESP, conheci professoras e alunas feministas, participei de palestras, de vários debates e de encontros resultantes da parceria entre o Centro de Referência da Mulher e a FCLAR. Ali entendi, enfim, a historicidade da categoria feminino e, aos poucos, fui me empoderando e descobrindo outras possibilidades para o que é padronizado como ser mulher.

Em 2002 procurei alguém que me orientasse em minha pesquisa de iniciação científica, já que no primeiro ano de graduação eu havia conhecido e me interessado por uma instituição social destinada a acolher mulheres e meninas em situação de risco, as quais se encontravam fora de seus lares justamente por sofrerem abuso sexual, estupro e violência doméstica. A dinâmica daquela instituição me deixou bastante curiosa: após algumas idas à entidade, percebi que, ao fornecer abrigo, tratamento médico e psicológico às internas, a instituição tinha como intuito maior a ressocialização à 
sociedade; no entanto, ao ali chegarem, tais mulheres eram culpabilizadas por estarem em situação de risco, tanto pelos(as) próprios(as) dirigentes da entidade, como também pelas internas que já estavam no local há mais tempo. Era justamente a partir dessa culpabilização que se iniciava todo um processo de socialização para transformá-las em mulheres recatadas e prendadas (COSTA, 2009).

Encontrei a orientação que necessitava no Núcleo de Estudos da Sexualidade (NUSEX), coordenado pelo Prof. Dr. Paulo Rennes Marçal Ribeiro. Elaboramos então um projeto que tinha como objetivo analisar práticas e valores referentes à sexualidade de adolescentes, considerando as mediações e intervenções institucionais nos comportamentos das mulheres envolvidas. Desenvolvido a partir do recorte de gênero, o trabalho contou com fomento da Fundação de Amparo à Pesquisa do Estado de São Paulo (FAPESP) nos anos de 2003 e 2004, tendo sido muito importante para meu crescimento como pesquisadora. Foram dois anos em contato direto com a literatura feminista, quando pude conhecer referenciais teóricos com os quais trabalho até hoje, tais como Michel Foucault, Joan Scott, Guacira Lopes Louro, entre outros(as).

Em 2005, com o término da bolsa de estudos da FAPESP, comecei a lecionar como professora eventual em uma escola pública de Araraquara e por dois anos substituí professores(as) que faltavam. Embora não houvesse uma frequência regular para minha entrada em sala de aula, pude perceber semelhanças entre a instituição social onde desenvolvi a pesquisa de iniciação cientifica e a escola em que estava trabalhando naquele momento.

Guacira Lopes Louro (2003) afirma que as instituições constituem o gênero e são igualmente constituídas por este. Nesse sentido, do mesmo modo em que via as internas aprendendo a se portarem como mulheres recatadas e prendadas, também observei, na escola, meninos e meninas aprenderem a se comportar de acordo com padrões desejados e reiterados pela sociedade a respeito de masculinidade e feminilidade.

Conforme via diretores(as), coordenadores(as), professores(as), agentes escolares e merendeiros(as) incrédulos(as) com o comportamento dos(as) adolescentes em relação a paqueras, ficadas e namoros - e, ao mesmo tempo, preocupados(as) em orientá-los(as) quanto a essas manifestações de sexualidade, recordava-me da minha própria experiência como aluna e adolescente. A escola continuava a trazer 
profissionais da saúde ou então a incumbir professores(as) de ciências, biologia e educação física da tarefa de falar sobre sexualidade para os(as) alunos(as); a atenção e o cuidado com o comportamento feminino, no sentido de que a mulher não deve provocar o homem, ainda permanecia; a afirmação da masculinidade como sinônimo de força e da feminilidade como marcada pela fragilidade se mantinha; o preconceito, com um misto de aceitação e excentricidade, em relação àqueles(as) que possuem orientação sexual diferente da heterossexual persistia, e assim por diante.

No entanto, se no passado eu havia sido aluna, agora eu era professora e, por mais que estudasse sexualidade e relações de gênero, encontrava dificuldades para abordar essas temáticas. Em alguns casos, sentia-me sem jeito de interferir na conversa entre os(as) alunos(as), por exemplo quando, certa vez, ouvi um rapaz dizer aos amigos que estava irritado com sua esposa e queria lhe dar um pé no ouvido.

Em outra ocasião, procurei falar de feminismo enfatizando a necessidade de autonomia e empoderamento das mulheres em relação aos homens, mas, ao final da aula, uma aluna bastante popular da sala, que namorava um garoto também popular, ameaçou-me dizendo que iria à diretoria, pois tudo o que eu havia dito era direcionado ao seu comportamento e eu não tinha direito de interferir em sua vida. Entre outras cenas, cito por último esta: em uma aula, ao abordar o feminismo, falei sobre Simone de Beauvoir e sua famosa frase: "Não se nasce mulher, torna-se mulher". Quando disse que também "não se nasce homem, torna-se homem", entrei em uma discussão com um aluno que afirmou que eu deveria estudar mais, afinal ele era enfermeiro e todos os dias via homens e mulheres nascendo no hospital.

Tais situações me direcionaram ao objeto de estudo de minha pesquisa de mestrado. Como docente, eu procurava entender de que maneira o curso de formação de professores(as) mediava e intervinha nas concepções de sexualidade e gênero dos(as) alunos(as) em suas próprias atuações em sala de aula. Para isso, elenquei o curso de Pedagogia da Faculdade de Ciências e Letras de Araraquara (UNESP) e selecionei como sujeitos da pesquisa as alunas que cursavam o último ano e que já atuavam como professoras.

Em 2007 iniciei o mestrado. A partir da análise das falas de sete entrevistadas e do currículo do curso de Pedagogia, averiguei que manifestações como descobertas 
corporais entre meninos e meninas e primeiros contatos sexuais (paqueras, namoros, toques e carícias) eram frequentes e até mesmo corriqueiras em sala de aula. Nos relatos analisados, foi possível perceber, ainda, dificuldades quanto ao trabalho com a sexualidade e com as relações de gênero, conteúdos que pouco foram desenvolvidos durante a formação acadêmica das entrevistadas. Tal aspecto foi confirmado na análise do currículo do curso de graduação em que estavam inseridas:

A falta de preparo para o trabalho de sexualidade e relações de gênero na escola nos leva a questionar a formação acadêmica destas alunas/ professoras. Em uma primeira leitura do currículo do curso de Pedagogia da FCLAr, constatamos que esses temas são tratados de maneira secundária na formação do (a) pedagogo (a) desta instituição. Ou seja, sexualidade e relações de gênero são mencionados por meio da aprendizagem de outros temas, como exemplo, a história da infância, da família, da profissão docente entre outros (COSTA, 2009, p. 124).

Já no ano de 2009, prestes a terminar o mestrado, comecei a participar como tutora do curso Gênero e Diversidade na Escola (GDE), no polo de São José do Rio Preto (SP). Trata-se de uma formação inserida na modalidade de Educação a Distância e oferecida a professores(as) com o objetivo de oferecer subsídios para o manejo das questões de sexualidade e relações de gênero que emergem na escola. O GDE é fruto de reivindicações por parte de determinados movimentos sociais - por exemplo, o feminista, o negro, o indígena e o gay (lésbicas, transexuais e transgêneros) -, bem como da parceria entre organizações governamentais e não governamentais, o Ministério da Educação (MEC), Secretarias - de Educação a Distância (SEED); de Políticas para as Mulheres; de Políticas de Promoção da Igualdade Racial; de Direitos Humanos; de Educação Continuada, Alfabetização e Diversidade (SECAD) - e a Universidade Aberta do Brasil (UAB). ${ }^{2}$

Como tutora a distância, minha função era auxiliar os(as) professores(as) no desenvolvimento de atividades na plataforma online Moodle, corrigir suas tarefas e suscitar discussões nos fóruns de debate sobre questões de sexualidade e relações de

\footnotetext{
${ }^{2}$ Mais adiante, no capítulo 1, tais articulações políticas constitutivas do GDE são explicadas em maiores detalhes.
} 
gênero. Durante minha atuação no curso, pude perceber que as mesmas angústias, dúvidas e incertezas que acompanhavam as estudantes de Pedagogia também persistiam entre os(as) professores(as) que participavam do GDE, os(as) quais, em sua maior parte, lecionavam na Educação Infantil e no Ensino Fundamental e já estavam no magistério há um tempo significativo.

Foi justamente a partir daquela experiência que pude formular as primeiras indagações que deram origem a esta tese de doutorado: afinal, após o curso, houve modificações nas diferentes formas de ser mulher e ser professora? Qual era a constituição de si mesma como mulher e professora antes e durante o curso?

Tais questionamentos levaram-me à construção do objetivo central deste trabalho, isto é, investigar as possíveis influências do curso sobre Gênero e Diversidade na Escola (GDE) na compreensão de seis professoras - atuantes no Ensino Fundamental da rede municipal de São José do Rio Preto (SP) - quanto aos múltiplos significados do que é ser mulher e ser professora, sob a ótica das relações de gênero. O referido objetivo geral, por sua vez, embasa os objetivos específicos listados a seguir:

- Verificar, no material produzido pelas professoras entrevistadas (registro das atividades desenvolvidas durante o curso na plataforma Moodle) e em seus relatos, em que medida a formação que visa ao desenvolvimento profissional docente acerca dos temas sobre sexualidade e relações de gênero pôde ou não influenciar em suas respectivas apreensões sobre as diferentes formas de ser mulher e ser professora;

- Analisar, no material produzido pelas professoras entrevistadas (registro das atividades desenvolvidas durante o curso na plataforma Moodle) e em seus relatos, em que medida o curso Gênero e Diversidade na Escola (GDE) pôde influenciar ou não em suas concepções e ações pedagógicas em sala de aula no que concerne às temáticas de sexualidade e relações de gênero.

A tese está dividida em três capítulos. No primeiro, procuro problematizar os conceitos de sexualidade e relações de gênero a partir da perspectiva históricosociocultural. Parto do pressuposto de que a sexualidade, como construção social, pode ser melhor compreendida com base na ideia de gênero, visto que é a partir dessa categoria que entendemos como se estruturam os corpos e as práticas sexuais em 
determinados contextos históricos. Ao enfatizar o caráter social e histórico das temáticas em pauta, relaciono-as à área da educação e promovo uma reflexão sobre a abordagem dessas questões no âmbito escolar. É nesse contexto que apresento o curso Gênero e Diversidade na Escola (GDE), o qual, por se tratar de uma formação voltada para o desenvolvimento profissional docente, objetivou a construção de uma política de educação para a diversidade. Destaco, ainda, que o foco da minha investigação se centrou no GDE ofertado pela Universidade Estadual Paulista "Júlio de Mesquita Filho" (UNESP), campus de Rio Claro (SP).

No segundo capítulo, dedico-me a descrever os caminhos metodológicos que percorri durante a realização desta pesquisa: defino a abordagem e os referenciais teóricos utilizados para interpretar os resultados; apresento os sujeitos, ainda que de forma genérica, bem como o contexto em que vivem; elenco os instrumentos que utilizei para a obtenção dos dados. Por fim, relato minha entrada em campo (as decisões que tomei, os obstáculos que enfrentei, os acertos que obtive e os contatos que mantive antes e durante a entrevista com os sujeitos) e a forma como organizei as informações a fim de viabilizar a pesquisa.

É no terceiro capítulo que dou início à análise dos dados, propriamente dita. Para tanto, classifiquei-os em torno das diferentes formas de ser mulher e ser professora, de modo a construir o perfil de cada uma das seis professoras entrevistadas. $\mathrm{Na}$ apresentação dos perfis, destaco suas histórias de vida, suas concepções sobre os temas em pauta e também suas reflexões, aprendizagens e resistências em relação ao curso Gênero e Diversidade na Escola (GDE).

Nas considerações finais, procuro refletir sobre o movimento de reprodução e, ao mesmo tempo, de resistência dessas docentes aos discursos e às regras engendradas pela sociedade patriarcal a respeito do que entendem por ser mulher e ser professora. Embora o GDE tenha provocado estranhamentos, questionamentos e confrontos à visão essencialista que tais mulheres possuíam sobre a sexualidade e as relações de gênero, há de se pensar nos entraves quanto à efetivação dessa aprendizagem, os quais se dão pela força dos processos de socialização e por alguns aspectos que ainda precisam ser ponderados e revisados em relação aos cursos que visam auxiliar o(a) professor(a) ao longo de seu desenvolvimento profissional docente. 
Assim, penso que esta tese, ao investigar as mais variadas concepções de ser mulher e ser professora a partir da participação de seis educadoras no curso GDE, lança novas possibilidades de reflexão sobre a formação de professores(as) no que tange às relações de gênero e sexualidade, bem como sobre as medidas de interferência das políticas públicas na educação. 


\section{SEXUALIDADE, RELAÇÕES DE GÊNERO E EDUCAÇÃO: INTERSEÇÕES COM O CURSO GÊNERO E DIVERSIDADE NA ESCOLA (GDE)}

Não posso ficar colado A natureza como uma estampa E representá-la no desenho Que dela faço

Não posso

Em mim nada está como é Tudo é um tremendo esforço de ser

SECOS \& MOLHADOS

(Angústia)

Considerar a sexualidade e o gênero como instâncias sociais que sofrem transformações na história é partir do pressuposto de que ambos não são simplesmente dados naturais, mas construções culturais que viabilizam os processos de socialização de homens e mulheres. Nesse sentido, parto da premissa de que a sexualidade e o gênero não são categorias definidas, coladas à natureza, e sim dimensões de um vir $a$ ser constante, lido, relido e moldado conforme os vários espaços e tempos históricos.

A partir das perspectivas simmeliana e eliasiana, entendo os processos de socialização como toda interação que ocorre entre indivíduo e sociedade. É a interação social entre os seres humanos que configura os valores, as formas de agir, as maneiras de pensar, a personalidade individual e, enfim, o sentido reprodutivo e criativo do agir social. De caráter móvel, dinâmico e não fixo, os processos de socialização não são lineares, nem sistemáticos; além disso, envolvem transformações estruturais, processuais e individuais que permeiam a vida do indivíduo (SIMMEL, 2006; ELIAS, 1994; GRIGOROWITSCHS, 2008). De acordo com essa lógica, considero que a sexualidade e as relações de gênero, assim como os valores, as crenças e os usos do corpo relacionados a tais instâncias, estão imersas nos processos de socialização, visto que as identidades sexuais são construções sociais também decorrentes de um processo que articula as referências institucionais à biografia dos sujeitos.

Há de se considerar, portanto, que, na construção da sexualidade e do gênero, as instituições sociais - como a família, a igreja, a política e a escola, entre outras possuem papel importante, pois fornecem modelos de masculinidades e feminilidades. 
A educação, área em que se insere o presente estudo, vem cada vez mais se tornando lócus de discussão para as questões sexuais e de gênero, visto que nela é possível se deparar tanto com dispositivos que direcionam a sexualidade para a heteronormatividade, quanto com a diversidade sexual e de gênero.

É justamente tal premissa que me leva, neste primeiro capítulo, a discutir os conceitos de sexualidade e relações de gênero, bem como sua articulação com a educação, sobretudo no que concerne à formação voltada ao desenvolvimento profissional docente. Em seguida, apresento o curso Gênero e Diversidade na Escola (GDE) e seus pressupostos relativos à construção de uma política educacional para a diversidade.

\subsection{Sexualidade e relações de gênero}

Falar de sexualidade é necessariamente falar de cultura. Por mais que sua associação ao sexo biológico seja constante, é preciso destacar sua relação com os hábitos, costumes e comportamentos aceitos e negados - tanto para homens, quanto para mulheres - em determinada sociedade.

Jeffrey Weeks (2000) esclarece que a presença do sexo biológico nas questões da sexualidade é um fato que não podemos negar. No entanto, a relação da cultura com o corpo tem um peso significativo na forma como lidamos com nossos desejos e prazeres sexuais. Como afirma o autor, "a sexualidade é, na verdade, 'uma construção social', uma invenção histórica, a qual, naturalmente, tem base nas possibilidades do corpo: o sentido e o peso que lhe atribuímos são, entretanto, modelados em situações sociais concretas" (WEEKS, 2000, p. 40). Na mesma perspectiva, Maria Luiza Heilborn (1999, p. 41) também define a sexualidade como uma construção histórica, afirmando ser necessário entendê-la como "uma unidade ficcional, dependente de um determinado contexto cultural e historicamente instituída como um domínio portador de sentido em si mesmo".

Há de se notar que esses dois autores, ao enfatizarem a associação entre sexualidade e cultura e ressaltarem o caráter histórico da primeira, fundamentam suas 
concepções em Michel Foucault (1985, p. 100), sobretudo quando esse autor define que sexualidade

[...] é o nome que se pode dar a um dispositivo histórico: não a uma realidade subterrânea que se apreende com dificuldades, mas a grande rede de superfície em que a estimulação dos corpos, a intensificação dos prazeres, a incitação do discurso, a formação do conhecimento, o reforço dos controles e das resistências encadeiam-se uns ao outros, segundo algumas grandes estratégias do saber e dos poderes.

Em sua obra História da sexualidade I: a vontade de saber (1985), Foucault procura fazer a história das instâncias de produção discursiva, de produção de poder e de produção de saber sobre o sexo. Nessa perspectiva, ao conceituar a sexualidade como um dispositivo histórico, o autor quer enfatizar a presença dessa instância em toda a malha social, visto que tal aparato

[...] engloba discursos, instituições, organizações arquitetônicas, decisões regulamentares, leis, medidas administrativas, enunciados científicos, proposições filosóficas. Em suma, o dito e o não dito são os elementos do dispositivo. O dispositivo e a rede que se pode estabelecer entre estes elementos" (FOUCAULT, 2000, p. 244).

Segundo Foucault, no século XVIII teria surgido a Scientia Sexualis, o que assinala uma proliferação de discursos sobre a sexualidade cujo objetivo seria a polícia do sexo, ou, em outras palavras, seu controle e sua regulamentação. Como o próprio autor explica,

[...] trata-se menos de um discurso sobre o sexo do que de uma multiplicidade de discursos, produzidos por toda uma série de mecanismos que funcionam em diferentes instituições. A idade média tinha organizado, sobre o tema da carne e da prática da confissão, um discurso estreitamente unitário. No decorrer dos séculos recentes, essa relativa unidade foi decomposta, dispersa, reduzida a uma explosão de discursividades distintas, que tomaram forma na demografia, na biologia, na medicina, na psiquiatria, na psicologia, na moral, na crítica política [...]. Em torno do sexo toda uma trama de variadas transformações em discurso, específicas e coercitivas? Uma censura maciça a partir das decências verbais impostas pela época clássica? Ao contrário, há uma incitação do discurso, regulada e polimorfa (FOUCAULT, 1985, p. 35). 
É justamente a partir desse contexto que Foucault refuta a ideia de uma repressão sexual nas sociedades industriais modernas do século XIX. Segundo ele, o que ocorre é justamente o contrário, ou seja, uma proliferação de discursos sobre o sexo, os quais, por sua vez, têm como objetos privilegiados de saber "a mulher histérica, a criança masturbadora, o casal malthusiano, o adulto perverso" (FOUCAULT, 1985, p. 100).

O surgimento dessas sexualidades periféricas e do saber em torno delas visaria ao controle e, consequentemente, ao exercício do poder sobre os corpos dos sujeitos. $\mathrm{O}$ poder voltado ao corpo, como "situação estratégica complexa numa sociedade determinada" (FOUCAULT, 1985, p. 100), é chamado pelo autor de biopoder, o qual, ao reforçar o saber sobre a população, conseguiria controlar os indivíduos. Desse modo, o autor afirma que a sexualidade que se origina em uma "sociedade normalizadora é o efeito histórico de uma tecnologia de poder centrada na vida" (FOUCAULT, 1985, p. $135)$.

A história da sexualidade escrita por Foucault nos leva a constatar que, por meio do mecanismo saber-poder, o conhecimento se tornou uma ferramenta valiosa de exercício do poder sobre os corpos. Assim sendo, o saber sobre o sexo faz da sexualidade não "aquilo que o poder tem medo; mas de que ela é, sem dúvida, e, antes de tudo, aquilo através de que ele se exerce" (FOUCAULT, 2000, p. 236).

Um conceito que pode ser tomado como categoria de análise esclarecedora das relações de poder relativas à sexualidade é o gênero. Como construção social, a noção de gênero nasce dentro do movimento feminista, transformando-se, ao longo das três fases do feminismo, ${ }^{3}$ em uma categoria analítica capaz de denunciar as várias e diferentes desigualdades entre homens e mulheres. ${ }^{4}$ Tal como observa Marília Pinto de Carvalho (2010, p. 514),

\footnotetext{
${ }^{3}$ Mais adiante, utilizo os escritos de Guacira Lopes Louro (2003) para explicar as fases do feminismo. Tal autora, por sua vez, elege a palavra onda para designar as transformações acerca desse movimento social.

${ }^{4}$ Quando me refiro ao fato de a categoria analítica de gênero ser capaz de denunciar as várias e diferentes desigualdades entre homens e mulheres, faço alusão à ideia de que a intersecção do gênero com outras categorias - como a sexualidade, a classe social, a raça, a geração e a nacionalidade - faz desse conceito uma eficaz ferramenta para verificação e análise das múltiplas relações de poder entre homens e mulheres, entre homens e entre mulheres. Nesse sentido, o cruzamento de tais categorias com
} 
[...] as sexualidades, embora constituam um campo próprio de estudos, só se tornam compreensíveis a partir do conceito de gênero, pois as ideias sobre gênero predominantes em um dado contexto social levam à atribuição, aos corpos e às práticas sexuais, de determinados sentidos ao invés de outros. O gênero é a "lente" por meio da qual olhamos, compreendemos e agimos frente aos corpos e à sexualidade.

Nesse sentido, pode-se dizer que o conceito de gênero foi desenvolvido pelos movimentos feministas, os quais são caracterizados por Manuel Castells (1999) como vitais, flexíveis e diversificados. Para esse autor, tais características não impedem a manutenção da essência do feminismo, pois, por mais que esse movimento social se manifeste de "formas e orientações diferentes, dependendo dos contextos culturais, instrucionais e políticos do local em que surgem" (CASTELLS, 1999, p. 224), ainda se mantém seu fundamento, isto é, "o esforço histórico, individual ou coletivo, formal ou informal, no sentido de redefinir o gênero feminino em oposição direta ao patriarcalismo"5 (CASTELLS, 1999, p. 211).

De acordo com Edla Eggert (2003), o feminismo é um movimento que possui uma multiplicidade de enfoques, o que leva a autora a referir-se a feminismos, no plural. Com base na divisão que Sandra Duarte de Souza (1999 apud EGGERT, 2003) faz de tal movimento social, a referida autora explica que ele pode ser fracionado em feminismo liberal, feminismo cultural, feminismo liberal contemporâneo, feminismo socialista, feminismo radical e ecofeminismo. Não obstante, a autora também considera que, apesar da diversidade de tendências, algo comum pode ser encontrado em todas essas vertentes:

[...] a crítica à concepção de possibilidade de universalização do Homem(sic), do conhecimento e da palavra tal como sendo uma verdade a ser seguida. Isso foi definido ideologicamente pelos teóricos com raízes marcadamente patriarcais. O movimento feminista vem denunciar que não há e nunca houve homens genéricos. O que existe,

o conceito de gênero permite-nos visualizar a dinâmica do poder não como uma força que vem de cima para baixo, mas como uma estratégia complexa presente na malha social (FOUCAULT, 1985).

${ }^{5}$ Para Manuel Castells (1999, p. 169), o patriarcalismo pode ser definido nos seguintes termos: "uma estrutura sobre as quais se assentam todas as sociedades contemporâneas. Caracteriza-se pela autoridade, imposta institucionalmente, do homem sobre a mulher e filhos no âmbito familiar. Para que essa autoridade possa ser exercida, é necessário que o patriarcalismo permeie toda a organização da sociedade, da produção e do consumo à política, à legislação e à cultura". 
segundo Sandra Haring, é a classificação de homem e mulher por intermédio do gênero (EGGERT, 2003, p. 5).

Guacira Lopes Louro (2003), por sua vez, ao elucidar a história dos feminismos, afirma que esse movimento social surge nos países do Ocidente e tem sua primeira $o n d a^{6}$ a partir da luta pelo sufrágio universal no século XIX. Segundo ela:

Seus objetivos mais imediatos (eventualmente acrescidos de reivindicações ligadas à organização da família, oportunidade de estudo ou acesso a determinadas profissões) estavam, sem dúvida, ligados ao interesse das mulheres brancas de classe média, e o alcance dessas metas (embora circunscrito a alguns países) foi seguido de uma certa acomodação no movimento (LOURO, 2003, p. 15).

Já a segunda onda teria tido seu início ao final dos anos 1960, remetendo, além das preocupações iniciais da primeira onda, à teorização e à problematização do conceito de gênero no meio acadêmico. Conforme argumenta Louro, dataria daquele momento a emergência dos estudos da mulher, os quais se caracterizam por críticas e denúncias a respeito da condição feminina, seja em livros, jornais, revistas ou manifestos públicos. Ao serem inseridos no âmbito acadêmico, tais estudos

[...] tiveram o mérito de transformar as até então esparsas referências às mulheres - as quais eram usualmente apresentadas como a exceção, a nota de rodapé, o desvio da regra masculina - em tema central. Fizeram mais, ainda: levantaram informações, construíram estatísticas, apontaram lacunas em registros oficiais, vieses nos livros escolares, deram voz àquelas que eram silenciosas e silenciadas, focalizaram áreas, temas e problemas que não habitavam o espaço acadêmico, falaram do cotidiano, da família, da sexualidade, do doméstico, dos sentimentos. Fizeram tudo isso, geralmente, com paixão, e se foi mais um importante argumento para que tais estudos fossem vistos como reservas. Eles, decididamente, não eram neutros (LOURO, 2003, p. 19).

Uma autora importante dessa segunda etapa dos feminismos é a filósofa francesa Simone de Beauvoir. Ao publicar O segundo sexo, em 1949, Beauvoir evidencia - ainda sem fazer menção ao conceito de gênero, que surgiria posteriormente - a construção

\footnotetext{
${ }^{6}$ Em lugar da palavra fase, a autora utiliza o termo onda para se referir às transformações no âmbito do movimento feminista.
} 
cultural do feminino, ou melhor, o modo "como a mulher faz o aprendizado de sua condição, como a sente, em que universo se acha encerrada, que evasões lhe são permitidas" (BEAUVOIR, 1980, p. 7).

Apesar de Beauvoir ter iniciado os questionamentos sobre a condição feminina, a inauguração do gênero como categoria de análise histórica se deu na denominada terceira onda dos feminismos. Nesse sentido, embora valorizassem as contribuições dos estudos da segunda onda, as análises que consideram o gênero como categoria explicativa não deixam de observar o caráter essencialista de alguns trabalhos daquele segundo momento, uma vez que, mesmo caracterizando o gênero como construção social, ainda tomavam o sexo como matriz das diferenças sociais entre homens e mulheres. A crítica de Linda Nicholson (2000, p. 11) ao que denomina fundacionalismo biológico explica bem o caráter assumido pelo sexo biológico em muitas das análises teóricas da segunda onda: "aqui o biológico foi assumido como a base sobre a qual os significados culturais são constituídos. Assim, no momento mesmo em que a influência do biológico está sendo minada, está sendo também invocada”.

Joan Scott é uma importante representante do feminismo da terceira onda. Com base nas influências teóricas pós-estruturalistas de Michel Foucault e Jacques Derrida, Scott escreveu Gender: a useful category of historical analysis ${ }^{7}$ em 1986, definindo gênero como "um elemento constitutivo de relações sociais fundadas sobre as diferenças percebidas entre os sexos, e o gênero é um primeiro modo de dar significado às relações de poder" (SCOTT, 1995, p. 14).

O conceito de gênero delimitado por Scott é composto por duas dimensões. A primeira refere-se ao fato de que, ao ser constituinte das relações sociais, o gênero consegue articular os símbolos e suas representações culturais, os conceitos normativos, as instituições e sua organização social e a identidade subjetiva. A partir da articulação desses elementos - que operam juntos, mas não simultaneamente -, teríamos

\footnotetext{
${ }^{7}$ Sob o título Gênero: uma categoria útil de análise histórica, o referido artigo foi traduzido por Guacira Lopes Louro e publicado em 1995 na revista Educação \& Realidade (v. 20, edição temática sobre Gênero e educação).
} 
percepções generalizadas de modos de ser, sentir e agir diferentes entre homens e mulheres.

Na segunda dimensão do conceito, Scott evidencia que, ao mesmo tempo em que é produto, o gênero também é produtor de poder. Como campo em que o poder se articula, o gênero distribui significações, bem como gera relações de força e provoca resistência entre os sujeitos. Dessa forma, a autora argumenta:

Seria melhor dizer: o gênero é um primeiro campo no seio do qual, ou por meio do qual, o poder é articulado. O gênero não é o único campo, mas ele parece ter constituído um meio persistente e recorrente de dar eficácia à significação do poder no Ocidente [...]. Estabelecidos como um conjunto objetivo de referências, os conceitos de gênero estruturam a percepção e a organização concreta e simbólica de toda a vida social. $\mathrm{Na}$ medida em que essas referências estabelecem distribuições de poder (um controle ou um acesso diferencial às fontes materiais e simbólicas), o gênero torna-se envolvido na concepção e na construção do poder em si mesmo (SCOTT, 1995, p. 16).

Por meio de tal definição, a autora mostra a necessidade da intersecção do conceito de gênero com outras categorias, como classe social, raça, sexualidade, nacionalidade e geração. Tal articulação permite desconstruir estereótipos, mostrandonos que homens e mulheres não são categorias fixas, mas instáveis e plurais. Ainda de acordo com Scott (1995, p. 93)

[...] nós só podemos escrever a história desse processo se reconhecermos que "homem" e "mulher" são, ao mesmo tempo, categorias vazias e transbordantes. Vazias, porque não têm nenhum significado último, transcendente. Transbordantes, porque mesmo quando parecem estar fixadas, ainda contêm dentro delas definições alternativas, negadas ou suprimidas.

Na mesma linha de pensamento, Lucilla Scavone (2008) esclarece que o caráter relacional, transversal e variável do gênero, além de possibilitar múltiplas análises e a produção de conhecimentos, fornece-nos também criticidade para avaliar situações sociais até então tidas como naturais em relação ao masculino e ao feminino. Nesse contexto, defende a autora:

Ao propor o uso da categoria Gênero para a análise histórica - e, por decorrência, para as ciências sociais -, pretende compreender e 
explicar significativamente o caráter relacional, transversal e variável dessa categoria analítica. Gênero é uma categoria de análise histórica, cultural e política, e expressa relações de poder, o que possibilita utilizá-la em termos de diferentes sistemas de gênero e na relação desses com outras categorias, como raça, classe ou etnia, e também levar em conta a possibilidade de mudança (SCAVONE, 2008, p. 179180).

Segundo Marília Carvalho (2011), o gênero, como categoria de análise proposta por Scott, permite-nos observar o uso da linguagem e suas implicações na construção do sistema simbólico. Em outras palavras, a elaboração de significados a partir da diferenciação sexual constitui fator preponderante para a compreensão de nossa atuação (como pensamos e agimos) em sociedade.

Nessa abordagem, o gênero aparece como um princípio de classificação que, embora emergindo da observação da natureza, mantém dela apenas a ideia básica da descontinuidade, da diferenciação e da hierarquia. Toda uma ordem simbólica extremamente variável em termos culturais e históricos - se originaria a partir daí, categorizando e hierarquizando o universo circundante em termos de gênero, de masculino e feminino. Parta Scott (1995), portanto, o gênero não é um conceito que descreva as relações entre homens e mulheres, mas uma categoria teórica referida a um conjunto de significados e símbolos construídos sobre a base da percepção da diferença sexual, significados estes que são utilizados na compreensão de todo o universo observado, incluído as relações sociais e, mais particularmente, as relações entre homens e mulheres (CARVALHO, 2011, p. 104).

$\mathrm{Na}$ condição de instâncias culturais, sexualidade e gênero são, portanto, categorias que estão interligadas. A maneira como nos concebemos como sujeitos sexuais é, igualmente, perpassada pela forma como nos entendemos como homens e mulheres em sociedade. Considerar a intersecção dessas categorias é de suma importância, pois a interdependência e a reciprocidade entre os dois conceitos evidencia como o poder se estrutura e atua socialmente.

Assim, ao considerarmos a sexualidade e o gênero como construtos sociais, é possível observar a fragilidade dos padrões que são fixados a homens e mulheres. Ademais, essa perspectiva histórica nos leva a pensar em possibilidades de mudanças no que tange a pensamentos ou ações não só em relação ao masculino e ao feminino, mas, sobretudo, no que diz respeito às esferas políticas e econômicas (CARVALHO, 2010). 
É justamente nesse sentido que se faz necessário destacar, segundo Carvalho (2010, p. 515), que o conceito de gênero está para além das análises que giram em torno das questões sexuais, já que, como categoria teórica, pode auxiliar "na compreensão de todo o universo observado, incluindo as relações sociais e, mais particularmente, as relações entre homens e mulheres". Logo, o uso da categoria de gênero para a análise da educação escolar torna-se fundamental "para iluminar nossas práticas e a formação de professores/as com um novo olhar" (CARVALHO, 2010, p. 525).

Fica evidente, portanto, a importância de compreendermos a sexualidade e o gênero como construtos sociais, bem como de utilizarmos tal categoria como ferramenta teórica para a compreensão de questões presentes na educação escolar, tais como: o entendimento de professores(as) como corpos sexuados expostos às relações sociais de gênero, o desenvolvimento profissional docente, as políticas públicas referentes a essa formação e as relações de sexualidade e gênero no cotidiano escolar, entre outras.

\subsection{Sexualidade, relações de gênero e educação}

Por intermédio dos processos sociais, criamos mecanismos que dão sentido à natureza, o que inclui os corpos. Consequentemente, tudo o que é cultural é passado de geração para geração por meio da linguagem, característica que confere à cultura possibilidades de mudança em sua configuração. Assim, quando se trata a sexualidade e o gênero no âmbito cultural, há de se admitir que essas instâncias são construídas no domínio das relações sociais e de suas redes de poder (LOURO, 2000a).

Se partirmos do pressuposto de que a sexualidade e o gênero são construções culturais, devemos concordar, então, que ambos são também categorias passíveis de aprendizagem. Nesse contexto, as instituições sociais - como a mídia, a família, a política, a igreja, a justiça e, sobretudo, a escola - exercem uma efetiva ação disciplinante sobre os corpos.

O disciplinamento dos corpos na escola encontra respaldo na cultura escolar, uma vez que esta engloba a aprendizagem de normas e práticas que variam conforme o tempo e o espaço históricos em que estão inseridas. Dominique Julia (2001), ao enfatizar o tratamento da cultura escolar como objeto histórico, define-a como 
[...] um conjunto de normas que definem conhecimentos a ensinar e condutas a inculcar, e um conjunto de práticas que permitem a transmissão desses conhecimentos e a incorporação desses comportamentos; normas e práticas coordenadas a finalidades que podem variar segundo épocas (finalidades religiosas, sociopolíticas ou simplesmente de socialização) (JULIA, 2001, p. 10).

Há de se observar que a cultura escolar funciona como um dispositivo da sexualidade, pois, ao estipular normas e práticas de maneira repetitiva, sutil e silenciosa, condiciona os corpos a se portarem conforme as regras socialmente aceitas. Justamente nesse sentido, é comum encontrarmos na escola fila de meninos e fila de meninas; grupos de meninos e grupos de meninas; meninas consideradas bagunceiras serem comparadas aos meninos, e meninos caprichosos serem comparados às meninas; meninos serem excelentes alunos em exatas, mas meninas serem esforçadas nas mesmas áreas; meninos que apresentam comportamentos femininos e meninas que apresentam comportamentos masculinizados serem ridicularizados, entre outros.

Tais ações e fatos, muitas vezes corriqueiros e até mesmo considerados normais no espaço escolar, afirmam a construção das identidades hegemônicas (homem, branco, classe média e heterossexual), pois, à medida que as identidades subordinadas são negadas, efetivam-se as identidades corroboradas pela norma. É dessa lógica, portanto, que emergem preconceitos, segregações e violências sexuais, bem como resistências por parte daqueles(as) que são rejeitados(as), afinal, “dizer eu 'sou gay' ou eu 'sou lésbica' significa fazer uma declaração sobre pertencimento, significa assumir uma posição específica em relação aos códigos sociais dominantes”(WEEKS, 2000, p. 70).

Ao problematizar os preconceitos, a opressão e a discriminação que sofrem os(as) jovens homossexuais na escola, Rogério Diniz Junqueira (2009b, p. 19) apresenta a suposição de que, "na escola, a homofobia produza efeitos sobre todo o alunado". Essa hipótese é reiterada pelo autor, uma vez que, ao reforçar a masculinidade hegemônica, a escola gera sofrimento em todos(as) que dela fazem parte, por exemplo, no garoto que precisa provar que é viril usando violência física e insultos sexistas, na garota que é incentivada a ser obediente e caprichosa, e, sobretudo, no(a) aluno(a) que é taxado(a) de homossexual por apresentar características que não são condizentes com o estereótipo de masculinidade socialmente aceito. De acordo com Junqueira (2009b), a homofobia pode afetar as trajetórias educacionais e formativas de jovens, visto que, ao 
estigmatizar, segregar e vulnerabilizar física e psicologicamente o sujeito que está à margem da normalidade, interfere no desenvolvimento pedagógico dos(as) alunos(as) e no desinteresse pela escola, o que pode, inclusive, resultar em evasão escolar.

Assim sendo, é possível observar que a escola, por intermédio de suas estratégias de poder, disciplina os corpos a direcionarem a sexualidade para a norma heterossexual. No entanto, cabe-nos perguntar: nós, professores(as), podemos, ao menos em parte, estabelecer a importância das relações de gênero e diversidade sexual na escola?

Em sua discussão sobre curiosidade, liberdade e sexualidade, Deborah Britzman (2000) nos explica que, ao serem relegadas às aulas de ciências, as questões sexuais acabam por ser tratadas de forma objetiva pela escola, o que lhes isenta, por completo, de seu caráter subjetivo. É justamente nesse contexto que "as discussões morrem, todo mundo começa a olhar para o relógio e os/as estudantes saem da aula sem ter obtido qualquer compreensão sobre suas preocupações, sobre seus desejos, sobre relações sexuais" (BRITZMAN, 2000, p. 86).

Segundo essa autora, os discursos que envolvem as questões sexuais em nossa sociedade estão envoltos por um pânico moral, o que dificulta discussões produtivas na escola. Partindo do pressuposto foucaultiano de que a sexualidade é uma construção histórica, Britzman (2000) postula que uma educação sexual só é eficiente quando fomenta identificações, desperta curiosidade e formula críticas. A esse respeito, expõe ela:

[...] se nós quisermos levar a sério as teorias sociais sobre a historicidade e o caráter problemático das construções - vistas como relações de poder - a pedagogia poderia, então, começar com o pressuposto de que as identidades são feitas e não recebidas e o trabalho do currículo consistiria em incitar identificações e críticas, e não em fechá-las. Além disso, uma educação sexual socialmente relevante pode apenas oferecer mais questões (BRITZMAN, 2000, p. 106).

No entanto, como assegura bell hooks (2000), a tradição ocidental tem como costume privilegiar a mente em detrimento do corpo, o que torna a aprendizagem institucional "um lugar onde o corpo tem de ser anulado, tem que passar desapercebido" (HOOKS, 2000, p. 115). De acordo com hooks, a cisão entre corpo e mente é tão forte em nossa tradição, que a afetividade entre professores(as) e alunos(as) é capaz de 
escamotear a capacidade e a competência de ambos. Nesse sentido, a autora reforça a necessidade de os(as) docentes resgatarem a paixão pela sala de aula e pelo ato de ensinar:

Não há muito ensino ou aprendizagem apaixonada na educação superior hoje em dia. Mesmo onde estudantes estão desesperadamente desejando ser tocados pelo conhecimento, professores e professoras ainda têm medo do desafio, ainda deixam que suas preocupações sobre perda de controle prevaleçam sobre seus desejos de ensinar (HOOKS, 2000, p. 122).

Há de se observar que falar de sexualidade e relações de gênero na escola não é tarefa fácil, tanto para os(as) alunos(as) quanto para os(as) professores(as). Os obstáculos são imensos, o que remete desde à ausência de materiais pedagógicos até a falta de preparo do(a) docente. Além disso, conforme já exposto, o pânico moral que envolve as questões sexuais impede, em muitos contextos culturais, o exercício de uma educação sexual eficiente na escola.

Paulo Rennes Marçal Ribeiro (1990) enfatiza que a França foi o primeiro país a estabelecer formalmente a relação entre sexualidade e escola. Em um primeiro momento, na segunda metade do século XVIII, a educação sexual naquele país tinha por objetivo afastar as crianças das questões sexuais. Já no final do século XIX, a apreensão francesa centrou-se na prevenção das doenças sexualmente transmissíveis, na degeneração das raças e nos abortos clandestinos. Por volta do início do século XX, o foco da prevenção recaiu sobre a relação entre instinto sexual e reprodução humana. Por fim, em 1973, a educação sexual foi incorporada ao currículo escolar francês.

Porém, tal como explica o referido autor, a Suécia foi o país que inaugurou uma educação sexual sistematizada. Ali, a educação sexual já era recomendada em 1942, tendo sido declarada obrigatória em 1956. Ademais, em 1938, o governo sancionou o livre acesso aos métodos contraceptivos, além de legalizar o aborto.

No Brasil, o processo de educação sexual, ainda segundo Ribeiro (2004), iniciase no período da colonização das Américas, isto é, no século XVI, estendendo-se em seis momentos. Ele esclarece que, aos olhos dos(as) colonizadores(as) portugueses(as), os(as) índios(as) não possuíam uma moral sexual. Nesse sentido, era necessário ensiná- 
los(as) a se portarem conforme os costumes europeus, o que, de acordo com o autor, constituiu o primeiro momento da educação sexual no Brasil.

O segundo momento, por sua vez, teria se dado a partir do estabelecimento da medicina como ciência no século XIX, o que foi acompanhado pela preocupação em higienizar os corpos. Já o terceiro momento seria marcado pelo surgimento da sexologia no século XX e pelo reconhecimento da importância da educação sexual.

Dos anos 1960 dataria o quarto momento, marcado pela inserção da sexualidade no currículo escolar e por sua extinção na ditadura militar dos anos 1970. A década seguinte, 1980, sinalizaria o quinto momento, o qual é caracterizado pelo reconhecimento da necessidade de se discutir sexualidade nas escolas pelos órgãos públicos. Naquele período, inclusive, foram propostos vários projetos de ação preventiva aos jovens.

Por fim, Ribeiro (2004) situa o início do sexto momento nos anos 1990 e aponta o apoio dos Parâmetros Curriculares Nacionais (PCN), documento elaborado pelo Ministério da Educação e do Desporto e publicado em 1998, valorizando a discussão escolar sobre temas transversais, tais como ética, pluralidade cultural, meio ambiente, saúde, estudos econômicos e orientação sexual. É necessário destacar que os PCN enfatizam que esses temas podem ser tratados em qualquer disciplina.

A valorização da sexualidade e das relações de gênero no currículo escolar leva a discussões teóricas sobre como deveria ser uma educação sexual eficaz no combate a preconceitos e violência sexuais. Jimena Furlani (2009), por exemplo, ao problematizar o uso da teoria queer, ${ }^{8}$ bem como das questões relativas a direitos humanos e direitos sexuais na escola, afirma que o primeiro passo para uma efetiva educação sexual seria o questionamento do que, até então, apresentava-se a nós como natural. Diz a autora:

\footnotetext{
${ }^{8}$ A teoria queer é uma perspectiva teórica e política que, segundo Tomaz Tadeu da Silva (2001) em Documentos de identidade: uma introdução às teorias do currículo, nasce dentro do movimento homossexual e tem por objetivo problematizar as identidades sexuais, especialmente a heterossexual. $\mathrm{O}$ autor explica que a palavra queer significa esquisito, estranho ou incomum. Conforme assinala Silva (2001), a teoria queer parte dos estudos de gênero, sobretudo os de cunho pós-estruturalista, e concebe as identidades de gênero e sexuais como construções sociais e discursivas que, longe de serem fixas, estão em constante mutação ou, em suas palavras, em "uma viagem entre fronteiras" (SILVA, 2001, p. 107).
} 
"Neste sentido, parece-me que, talvez, o primeiro aspecto de uma pedagogia queer escolar consista na crítica desconstrutiva da educação dominante, que apresenta a heterossexualidade como a identidade hegemônica, compulsória e incontestável" (FURLANI, 2009, p. 320).

Rogério Diniz Junqueira (2009a, p. 411), por sua vez, critica a forma como o tema orientação sexual é tratado pelos PCN, uma vez que, ao enfatizar as doenças sexualmente transmissíveis, a AIDS e a gravidez na adolescência, tal documento "não faz menção explícita às homossexualidades e mantêm total silêncio sobre as transgeneridades". Desse modo, o autor pressupõe a presença e a valorização da diversidade no processo educacional e na construção do conhecimento como forma de reconhecimento do outro e, consequentemente, de um "aprendizado da existência compartilhada, pacífica, cidadã e democrática” (JUNQUEIRA, 2009a, p. 411). Assim sendo:

"Educar na diversidade", neste sentido, pressupõe o empenho para desestabilizar qualquer pretensão, ressentimento, intolerância ou ódio alimentados pelo "narcisismo das pequenas diferenças". Requer, portanto, o desenvolvimento de uma postura de abertura em relação ao "outro": de acolhimento, de reconhecimento da legitimidade da diferença e de rediscussão acerca dos processos de produção de diferença e dos mecanismos de distinção e hierarquização entre todos os sujeitos envolvidos (JUNQUEIRA, 2009a, p. 414).

Ao discutir a articulação entre diversidade sexual e políticas de inclusão escolar, Fernando Seffner (2009) reitera que a escola, longe de ser um espaço que inclui os diferentes sujeitos, é uma instituição que os exclui. Para ele, embora vivamos em um momento em que o acesso à escola constitui um direito de todos(as), na prática esse direito não se cumpre, pois a grande dificuldade da instituição está justamente em saber como lidar com a diversidade de público que recebe, seja esta sexual, religiosa, étnica ou geracional, entre outras. Como consequência, em vez de incluir e acolher os sujeitos em sua diversidade humana, a escola os afugenta.

Nesse sentido, Seffner (2009) assegura a necessidade de a escola reconhecer a diversidade existente entre os(as) alunos(as) que recebe todos os dias, bem como promover respeito e aceitação das diferenças. Reflete o autor: 
O ingresso, a acolhida e a efetiva inclusão de alunos gueis, alunas lésbicas e jovens travestis, para ficar apenas nesses três exemplos de diversidade sexual, exigem da estrutura escolar muita modificação. A primeira é a abolição das piadas e das manifestações sexistas, tão comuns entre professores e professoras, acerca dos alunos e das alunas "diferentes" dos padrões heterossexuais ditos "normais". Não é possível educar num ambiente de falta de respeito, e a agressão verbal e até mesmo física - tem sido uma arma de expulsão de indivíduos que não se enquadram na regra da heteronormatividade. É necessário construir um ambiente de respeito e aceitação, o que não significa permitir que todos os desejos dos alunos em relação à vida amorosa e particularmente sexual sejam admitidos na escola (SEFFNER, 2009, p. 132).

Diante desse cenário, é necessário destacar a relevância das políticas públicas educacionais para o exercício de uma educação sexual que valorize a diversidade. Cláudia Vianna (2012) assinala a preocupação com uma agenda de sexualidade e de gênero voltada para a educação desde 1995, impulsionada pelas reivindicações dos movimentos de mulheres, pelas pressões externas do Banco Mundial, da Cepal e da UNESCO, bem como pelos debates junto ao MEC durante o governo de Fernando Henrique Cardoso. A partir dessa pressão, conforme aponta a autora, teve início a elaboração do Referencial Curricular Nacional para a Educação Infantil e dos Parâmetros Curriculares Nacionais (PCN) para o Ensino Fundamental, em 1997.

No entanto, as tentativas de incorporação de tais documentos no ambiente escolar teriam se deparado com as dificuldades em se discutir os temas, com a falta de preparo do(a) professor(a) e com a escassez de materiais pedagógicos para trabalhar sexualidade e relações de gênero em sala de aula. Além de tecer críticas a respeito do caráter biológico e médico com que a sexualidade é tratada nos PCN, Vianna (2012) chama a atenção para a pouca, ou quase nenhuma, ênfase dada à diversidade sexual, visto que essa temática aparece somente na introdução - tanto do documento quanto dos temas transversais -, sendo citada como assunto a ser trabalhado na quinta série do Ensino Fundamental.

De acordo com a pesquisadora, as políticas públicas educacionais que privilegiam a diversidade sexual surgem no governo de Luís Inácio Lula da Silva a partir da atuação de diferentes atores políticos e da criação de secretarias, como a Secretaria Especial de Direitos Humanos (SEDH), a Secretaria Especial de Políticas para Mulheres (SPM), a Secretaria Especial da Promoção da Igualdade Racial (SEPPIR) 
e a Secretaria Nacional da Juventude (SNJ). No mesmo período, conforme explica Vianna (2012), foram criadas no Ministério da Educação a Secretaria de Inclusão Educacional (SECRIE), a Secretaria Extraordinária de Erradicação do Analfabetismo (SEEA) e a Secretaria de Educação Continuada, Alfabetização e Diversidade (SECAD), sendo esta originada em 2004. Portanto:

A partir da criação da Secad, canalizaram-se para a agenda governamental do MEC temas e sujeitos que dela estavam excluídos. Com a presença desses setores nos espaços da administração pública, assistimos à conversão de antigas denúncias em propostas de políticas públicas federais (VIANNA, 2012, p. 8).

Ainda de acordo com Vianna (2012), a SECAD é uma secretaria imprescindível para as políticas de inclusão, uma vez que é por meio desse órgão que se engendram propostas e projetos de políticas públicas para a educação, sobretudo no âmbito da formação docente e no que se refere aos temas sexualidade, relações de gênero e diversidade sexual. Assim sendo, é a partir das ações efetuadas pela SECAD que, diz a autora, o Ministério da Educação lança programas de governo com ênfase na diversidade, entre os quais podemos mencionar: Brasil sem Homofobia (2004); Formação de Profissionais da Educação para a Cidadania e a Diversidade Sexual (2005/2006); e Gênero e Diversidade na Escola (2007), curso que constitui objeto de estudo da presente tese.

Destaco que com a extinção da Secretaria de Educação Especial (SEEP), a SECAD passou a incorporar o eixo da Inclusão, sendo denominada, a partir de 2011, de Secretaria de Educação Continuada, Alfabetização, Diversidade e Inclusão (SECADI). Conforme explicam Giovani Ferreira Bezerra e Doracina Aparecida de Castro Araujo (2014), a incorporação do tema Educação Especial à SECADI contribuiu para uma fragmentação e simplificação dos temas a serem trabalhados por essa secretaria, visto que:

[...] como será possível à SECADI dirimir, sem uma alteração radical no direcionamento do MEC, as questões indígenas, a alfabetização, a educação de jovens e adultos, a educação do campo, a educação especial, a educação ambiental, a educação quilombola, a educação em direitos humanos, e toda a sorte de mais diversidades que se lhe acrescentem, senão pela via da fragmentação disciplinar, eufemisticamente denominada de intersetorialidade? (BEZERRA; ARAUJO, 2014, p. 115) 
Pode-se dizer, enfim, que diante de um cenário político tenso e marcado por extremo preconceito no que tange à diversidade sexual, em que alguns sujeitos são marginalizados em detrimentos de outros, a relação entre sexualidade, gênero e educação mostra-se conflituosa. No entanto, para amenizar esse conflito, algumas medidas tornam-se apostas no sentido de uma educação para a diversidade, a exemplo da criação de políticas públicas no âmbito da formação docente. É justamente nesse contexto, como vimos, que surge o curso Gênero e Diversidade na Escola (GDE), o qual será apresentado a seguir.

\subsection{Desenvolvimento profissional docente e o curso Gênero e Diversidade na Escola (GDE)}

A iniciativa de criação do curso Gênero e Diversidade na Escola (GDE) justificase pelo fato de que, como muitos outros espaços sociais, a escola é um lugar sexualizado: “a sexualidade não é algo que possa ser ligado ou desligado, do qual alguém possa se despir. Ela está na escola porque faz parte do sujeito" (LOURO, 2003, p. 81). Dessa forma, ainda que a sexualidade e a diversidade dela decorrente, muitas vezes, sejam controladas e não aceitas pela instituição escolar, há de se considerar que o dispositivo sexual está presente nos vários segmentos da sociedade, sobretudo na escola.

Não há como negar que as concepções que professores e professoras possuem sobre sexualidade e relações de gênero fazem parte das relações pedagógicas. Como afirma Cláudia Vianna (2001/2002), a forma como nos construímos está associada à maneira como atuamos, como concebemos o mundo. Portanto, as concepções que os(as) docentes possuem sobre as relações sociais de gênero fazem parte das identidades docentes e das relações pedagógicas, ou seja, da maneira como lidam e se posicionam perante tais assuntos.

Nesse contexto, segundo Vianna (2001/2002), o conceito de gênero, como construção histórica, social e cultural, torna-se uma ferramenta valiosa, pois procura desvendar a falácia da defesa do caráter biologizante que envolveria a relação entre femininos e masculinos:

Não se trata de afirmar que sempre foi assim ou que é inerente à nossa "natureza". Trata-se, sim, de afirmar que as expressões de 
masculinidade e da feminilidade são historicamente construídas e referem-se aos símbolos culturalmente disponíveis em uma dada organização social, às normas expressas em suas doutrinas e instituições, à subjetividade e às relações de poder estabelecidas nesse contexto (VIANNA, 2001/2002, p. 90).

Tanto a teoria quanto nossas experiências como sujeitos evidenciam que a sexualidade e as relações de gênero são constituintes dos sujeitos, estão presentes na escola e fazem parte das relações pedagógicas. Entretanto, também fica evidente, sobretudo na perspectiva dos estudos de gênero e sexualidade na escola, que o(a) professor(a) não recebe formação necessária para trabalhar com esses temas em sala de aula. Há de se perguntar, assim: quais são as possibilidades de o(a) professor(a) obter conhecimentos sobre tais assuntos e aplicá-los didaticamente em seu cotidiano escolar?

A partir dos anos 2000, uma das alternativas possíveis de formação docente em sexualidade e relações de gênero foi o curso Gênero e Diversidade na Escola (GDE). É preciso destacar que o GDE pode ser pensado, entre as várias denominações possíveis, como inserido nas modalidades de formação contínua, formação continuada, formação permanente, formação em serviço, reciclagem ou desenvolvimento profissional docente. Embora essas categorias tenham características em comum - de modo geral, referem-se a um conjunto de atividades de formação em nível superior que visam ao aprimoramento do(a) professor(a) depois de sua formação inicial -, utilizarei a expressão desenvolvimento profissional docente para me referir à formação docente.

A opção pela expressão desenvolvimento profissional docente deve-se ao fato de esse conceito, como ressalta Carlos Marcelo (2009), explicitar melhor a ideia de que o(a) professor(a) é um(a) profissional do ensino. Conforme expõe o autor, trata-se de uma expressão que se refere a um processo a longo prazo, o que "supera a tradicional justaposição entre formação inicial e formação contínua dos professores” (MARCELO, 2009, p. 9). Além disso, "integra diferentes tipos de oportunidades e experiências, planificadas sistematicamente, de forma a promover o crescimento e desenvolvimento profissional dos professores" (MARCELO, 2009, p. 10).

Nesse sentido, após levantar definições antigas e atuais sobre o desenvolvimento profissional docente, o pesquisador reitera algumas características desse tipo de formação, tais como: a construção do conhecimento que se dá de maneira ativa e a 
longo prazo, o que faz do(a) professor(a) um(a) prático(a) reflexivo(a); a prioridade das experiências que têm como referência a escola e as atividades do(a) professor(a); a relação direta com a reforma da escola, isto é, da cultura escolar; o caráter colaborativo; o fato de não se desenvolver de maneira idêntica nos diferentes contextos, ou seja, de não possuir um modelo fechado. É nesse âmbito que Marcelo (2009, p. 10) define o desenvolvimento profissional docente como

[...] um processo, que pode ser individual ou colectivo, mas que se deve contextualizar no local de trabalho do docente - a escola - e que contribui para o desenvolvimento das suas competências profissionais através de experiências de diferente índole, tanto formais como informais.

O autor salienta, ainda, a importância da identidade profissional, o que ele define como a construção do eu profissional ou como "a forma como os professores se definem a si mesmos e aos outros" (MARCELO, 2009, p. 11) no andamento do desenvolvimento profissional docente. Ou seja, para ele, fatores como a escola, as reformas e os contextos políticos, bem como as concepções e as crenças dos(as) professores(as), influenciam diretamente nas disposições para aprender e desenvolver a atividade docente.

Em vista disso, ao utilizar a expressão desenvolvimento profissional docente, enfatizo a formação docente que prioriza uma aprendizagem sistematizada e que, estando em decurso, visa a transformações no âmbito da escola e do trabalho pedagógico do(a) professor(a). Sendo assim, esclarece Marli André (2010) a respeito da formação docente:

O que podemos concluir das leituras dos autores mais recentes é que a formação docente deve ser pensada como um aprendizado profissional ao longo da vida, o que implica o envolvimento dos professores em processos intencionais e planejados, que possibilitem mudanças em direção a uma prática efetiva em sala de aula (ANDRÉ, 2010, p. 176).

É justamente nesse âmbito - em que transformações decorrentes da sociedade contemporânea afetam diretamente o sistema educacional, acarretando a necessidade de o(a) professor(a) ampliar e aprimorar seus conhecimentos - que o projeto-piloto do curso semipresencial Gênero e Diversidade na Escola emerge, tendo 
[...] como propósito a construção de uma política de educação para a diversidade que questione estereótipos, preconceitos, desigualdades de gênero, étnico-raciais, a discriminação por orientação sexual e por identidade de gênero. Estas desigualdades contribuem para a injustiça social que ainda persiste no âmbito da escola (CARRARA et al., 2011, p. 35).

Ao apresentar as ideias que originaram a constituição do curso, Sérgio Carrara et al. (2011) expõem que muitas parcerias entre órgãos governamentais e não governamentais, bem como discussões e trocas de experiências entre ativistas de movimentos sociais e pesquisadores, foram de suma importância para o desenvolvimento do projeto. Segundo os autores, o reconhecimento da exclusão social presente em nosso país se dá somente a partir da Constituição de 1988, momento em que temos uma abertura política favorável às reinvindicações de grupos provenientes de movimentos sociais, tais como o feminista, o negro, o indígena e o gay (lésbicas, transexuais e transgêneros). A exigência de políticas públicas antidiscriminatórias, sobretudo no campo educacional, teria gerado, então, a criação de secretárias públicas:

Como uma resposta a estas demandas, a partir de 2003 foram criadas a Secretaria de Políticas para as Mulheres; a Secretaria de Políticas de Promoção da Igualdade Racial; e a Secretaria de Direitos Humanos (SDH/PR).

A percepção de que o desenvolvimento da luta contra as desigualdades sociais devesse ocorrer, necessária e fundamentalmente, através da educação fez com que, em 2004, fosse instituída a Secretaria de Educação Continuada, Alfabetização e Diversidade (SECAD), no âmbito do ministério da Educação (MEC) (CARRARA et al., 2011, p. $15)$.

Segundo Carrara et al. (2011), as articulações dessas secretarias com o MEC para a elaboração de políticas públicas na área da educação contaram, ainda, com a parceria da Secretaria de Educação a Distância (SEED) e com a Universidade Aberta do Brasil (UAB), a qual consiste em "um sistema integrado por universidades públicas que oferece cursos de nível superior para indivíduos que têm dificuldade de acesso à formação universitária presencial, por meio do uso da metodologia da educação a distância” (CARRARA et al., 2011, p. 19). Têm-se, a partir da união desses órgãos, 
pressupostos para a criação de um curso voltado para a formação de professores(as), no âmbito da Educação a Distância $(\mathrm{EaD})^{9}$.

As parcerias com setores que produzem conhecimento acerca dos temas gênero, sexualidade e relações étnico-raciais - a saber, o Centro Latino-Americano em Sexualidade e Direitos Humanos (CLAM/IMS/UERJ) e o British Council - também foram relevantes para a constituição do curso GDE. Ademais, marcos político-legais como a Declaração Universal dos Direitos Humanos (1948), a Convenção sobre a Eliminação de Todas as Formas de Discriminação contra a Mulher - CEDAW (1979), a Declaração e Plataforma de Ação de Pequim (1995), a Declaração Universal sobre Diversidade Cultural (2001), a Declaração e o Programa de Ação da Conferência Mundial contra o Racismo, Discriminação Racial, Xenofobia e Discriminações Correlatas (2001), a Constituição Federal (1988), a Lei de Diretrizes e Bases da Educação Nacional (1996), os Parâmetros Curriculares Nacionais (1997), a Política Nacional de Promoção da Igualdade Racial (2003), o Brasil Sem Homofobia: Programa de Combate à Violência e à Discriminação contra GLTB e de Promoção da Cidadania Homossexual (2004) e o Plano Nacional de Políticas para as Mulheres (2004) fortificaram a necessidade de políticas públicas educacionais para o combate do preconceito e da discriminação (CARRARA et al., 2011).

No entanto, tal como explicam Carrara et al., é somente com a realização do $I$ Seminário Internacional Educando para Igualdade de Gênero, Raça e Orientação Sexual, em 2004, evento articulado entre a Secretaria de Políticas para as Mulheres (SPM/PR), o British Council e o Ministério da Educação (MEC), que se concretizam a ideia e a necessidade de um curso sobre gênero, sexualidade e raça/etnia na formação de professores(as). Ao congregar pesquisadores(as) e ativistas dos movimentos sociais -o feminista, o de mulheres negras e o LGBT -, o Seminário, além de discussões e trocas de experiências acerca dos temas tratados, apresentou três questões fundamentais:

\footnotetext{
${ }^{9} \mathrm{Na}$ perspectiva de Fabiana Marques Costa (2011, s/p), o termo EaD remete ao "Ensino Aberto e a Distância, uma junção de dois métodos de ensino, que centram na expansão do acesso ao ensino. Segundo Rumble (2003) é caracterizado por dois fatores: a sua filosofia e o uso da tecnologia. A maioria dos sistemas de EaD tem uma filosofia que visa remover barreiras a educação e permitir a estudantes buscar: 'o que' quiserem; 'quando' quiserem; 'onde' quiserem'. Frequentemente, a sigla EaD é igualmente usada como Educação a Distância.
} 
1. A discussão conjunta dos três temas - gênero, orientação sexual e relações étnico-raciais - possibilitou o debate entre atrizes e atores do movimento social que geralmente dialogam no interior de seus grupos, mas não entre si, além de promover as trocas entre estes movimentos e os/as autores/as de pesquisas e estudos sobre os temas;

2. Constatação da urgência para o tratamento conjunto das temáticas relacionadas ao sexismo, ao racismo e à homofobia, seja na formação de professores/as, seja nos materiais didáticos com os quais trabalham nas escolas, e que disseminam estereótipos;

3. Consenso acerca da necessidade, prioritária, de formação de profissionais da educação nas temáticas de gênero, orientação sexual e relações étnico-raciais. Estas definições subsidiaram a escolha das metodologias a serem utilizadas e do conteúdo programático considerado essencial para a formação de professores e professoras nas referidas temáticas e sua interseção (CARRARA et al., 2011, p. 28).

A partir da realização desse evento e da parceria entre setores governamentais e não governamentais, surgiu o projeto-piloto do curso Gênero e Diversidade na Escola. Maria Elizabete Pereira e Maria Elisa Brandt (2007) esclarecem que o GDE foi lançado em um projeto-piloto em 24 de maio de 2006 e contemplou seis cidades de diferentes Estados: Dourados (MS), Maringá (PR), Niterói (RJ), Nova Iguaçu (RJ), Porto Velho (RO) e Salvador (BA). É necessário destacar que, para a efetivação do curso, tais cidades foram conveniadas às instituições realizadoras do curso.

Conforme expõe Dirce Grosz (2008), três critérios foram considerados na seleção dessas cidades:

$\mathrm{O}$ primeiro deles foi $\mathrm{o}$ da territorialidade, possibilitando a representação de todas as regiões geográficas do Brasil (Norte, Nordeste, Centro-Oeste, Sudeste e Sul). O segundo critério considerado foi o de municípios com diferentes perfis de localização e tamanho, selecionando-se, assim, municípios de médio e grande porte, capital, região metropolitana e afastados da capital. O terceiro critério utilizado foi a da articulação político-institucional: todos os municípios envolvidos no projeto-piloto possuem Coordenadoria Municipal de Mulheres e uma articulação para a igualdade racial, como coordenadoria, núcleo ou fórum (GROSZ, 2008, p. 38).

Sobre o projeto-piloto, Grosz (2008, p. 37-38) afirma que o GDE foi destinado para os(as) professores(as) do Ensino Fundamental e buscou "oferecer condições de transformações das práticas pedagógicas desses profissionais, desconstrução de preconceitos e rompimento com o ciclo de sua reprodução na escola". A autora relata, 
ainda, que o curso totalizou 200 horas, das quais 30 foram presenciais e 170 a distância. Tal carga horária foi estruturada em 5 módulos: I. Abertura, com ênfase no tema diversidade; II. Gênero; III. Sexualidade e Orientação Sexual; IV. Relações ÉtnicoRaciais; e V. Avaliação (PEREIRA et al., 2007).

O ambiente virtual utilizado para a realização do projeto-piloto do GDE foi o eProInfo $^{10}$ e contou com tutores(as) para orientação dos cursistas. Destaca-se que a metodologia do projeto pedagógico fundamentou-se nos princípios de Paulo Freire, Jean Piaget, Lev Vigotsky e Edgar Morin, procurando formar um sujeito crítico, autônomo e engajado. Desse modo, ao participar da plataforma virtual, o(a) professor(a) era convidado(a) a questionar, discutir, estudar e refletir sobre suas práticas pedagógicas no que concerne às relações de gênero, à orientação sexual e à raça/etnia (GROSZ, 2008).

Carrara et al. (2011) assinalam que, antes de a primeira versão do GDE se estender para os outros Estados e municípios, foram realizadas avaliações com os(as) professores(as) que participaram do projeto-piloto. Tais avaliações evidenciaram que a escola é um dos espaços mais reprodutores de preconceito e discriminação, cujos principais alvos seriam, em ordem decrescente, a orientação sexual, a raça/etnia e as relações de gênero. Ademais, destacam os autores que as avaliações ainda revelaram a predominante presença das mulheres no magistério, o preconceito em torno da figura do professor homem, muitas vezes associado a homossexualidade ou pedofilia, bem como a importância da figura do(a) professor(a) na desconstrução de estereótipos e no combate à discriminação.

Contudo, as avaliações também demonstraram repercussões positivas do GDE na vida dos(as) professores(as), sendo tais efeitos de ordens diversas: pessoal, profissional, institucional ou político-pedagógica. Nesse sentido, tal como apontam Carrara et al. (2011), quando os relatos dos(as) cursistas evidenciam a consciência da necessidade de desconstrução de paradigmas, a mudança na forma de olhar e tratar o(a) outro(a), e a transferência das discussões ocorridas nos fóruns para a realidade escolar como forma

\footnotetext{
${ }^{10}$ Sobre o e-ProInfo, Dirce Grosz (2008, p. 39) esclarece que se trata de "um ambiente colaborativo de aprendizagem que utiliza a tecnologia internet e permite a concepção, administração e desenvolvimento de diversos tipos de ações, como cursos a distância, complemento a cursos presenciais, projetos de pesquisa, projetos colaborativos e diversas outras formas de apoio a distância e ao ensino e aprendizagem".
} 
de pensar o projeto político-pedagógico da escola, é possível entender e reconhecer o papel do GDE como projeto de educação inclusiva que tem seus princípios fundamentados na democracia e na cidadania.

O resultado das avaliações, portanto, certificou a relevância das temáticas sexualidade, relações de gênero e raça/etnia no projeto político-pedagógico da escola. É nesse contexto que, desde o ano de 2008, o MEC abre edital do curso Gênero e Diversidade na Escola para as Instituições de Ensino Superior Públicas, as quais atuam pelo sistema da Universidade Aberta do Brasil (UAB).

A partir de 2008, podemos encontrar várias ocorrências do curso GDE, bem como estudos acerca dessas experiências. Em pesquisa no Banco de Teses e Dissertações da Coordenação de Aperfeiçoamento de Pessoal do Nível Superior (CAPES), pude averiguar vários trabalhos que problematizam o desenvolvimento profissional docente em sexualidade e relações de gênero, assim como a participação, a aprendizagem e a vivência de professores(as) na realização desse curso.

Em buscas na plataforma CAPES pelas expressões desenvolvimento profissional docente em sexualidade, desenvolvimento profissional docente em relações de gênero, formação continuada em sexualidade, formação continuada em relações de gênero, curso Gênero e Diversidade na Escola e GDE, deparei-me com 11 trabalhos em formato online, os quais versam a respeito do GDE desde seu projeto-piloto até o presente momento. Também encontrei outras ocorrências que apenas disponibilizavam o acesso ao resumo, o que me impediu de ter uma melhor compreensão do trabalho como um todo. Assim, restringi-me a sete dissertações de mestrado e a quatro teses de doutorado, as quais se encontram online e possuem recortes empíricos semelhantes ao meu no que se refere à forma de mostrar avanços, entraves, contribuições e problemas advindos da formação docente na perspectiva de gênero e sexualidade.

A partir da leitura de tais trabalhos, tornou-se evidente que o curso GDE representa uma política pública de orientação moderna, visto que valoriza a diversidade entre os sujeitos e possui uma visão que se embasa nas ciências sociais, perspectiva sociocultural que vem ganhando cada vez mais espaço nas análises referentes à sexualidade e às relações de gênero. Todavia, a complexidade acerca do trabalho dessas temáticas na escola leva os estudos acerca desse curso a questionarem sobre as 
possibilidades e os limites do GDE como política pública educacional. Nesse cenário, várias dissertações e teses indicam dificuldades, obstáculos e resistências quanto à revisão de valores relativos às temáticas propostas no curso (MOSTAFA, 2009; ASSUMPÇÃO, 2012; CERQUEIRA, 2012; SILVA, 2013; TEIXEIRA, 2014; SAMPAIO, 2014; PEREIRA, 2014; QUARTIERO, 2014; NUNES, 2015; GARCIA, 2015; SILVA, 2015).

Um dos primeiros apontamentos verificados pelos estudos refere-se às resistências dos(as) educadores(as) perante a abordagem da sexualidade e das relações de gênero na escola, visto que carregam consigo preconceitos culturalmente construídos em torno dessas temáticas. Em virtude disso, como averigua Maria Mostafa (2009), alguns(as) cursistas/ professores(as) fundamentam suas concepções sobre sexualidade e gênero nas perspectivas de uma moral privada e médica. Tal entendimento, por sua vez, limita o trabalho do(a) docente como educador(a) sexual, levando muitos(as) professores(as) a atribuírem a tarefa de educar e orientar sexualmente a profissionais da saúde, como psicólogos(as) e enfermeiros(as).

Nessa perspectiva, o trabalho de Ednalva Macedo Nunes (2015) encontra várias falas dos(as) cursistas que remetem ao gênero somente pela ótica dicotômica - isto é, homem/ mulher - e que abordam o sexo e a sexualidade como instâncias biológicas carregadas de pecado e imoralidade. A autora também constata nos discursos dos(as) docentes dificuldades em se trabalhar pedagogicamente as relações de gênero e sexualidade na escola, visto que, além da falta de preparo dos(as) professores(as) para essa tarefa, esses temas são difíceis de serem discutidos, ainda mais quando é necessário envolver a família do(a) aluno(a). Assim:

Nas transcrições sobre gênero e sexualidade, em vários momentos, restringem à teoria e sua aplicabilidade na escola não é discutida. Embora os/as cursistas tenham tido acesso ao material, muito do que foi lido ainda permanece no campo teórico, suscitando indagações sobre sua aplicabilidade no âmbito escolar, denotando a insipiência do assunto e seu caráter relativamente novo, bem como a necessidade de debate na escola sobre a temática (NUNES, 2015, p. 74).

Além da falta de preparo e da dificuldade inerente ao tema, outros obstáculos foram assinalados pelos(as) professores(as)/cursistas para o exercício de uma educação sexual, tais como: a sobrecarga de mais uma função a ser desenvolvida pelo(a) docente; 
o pouco tempo de que dispõem em contato com o(a) aluno(a); a falta de conhecimento e as dificuldades decorrentes do fato de tratar de temas que envolvem crenças e valores; a falta de respaldo por parte das autoridades escolares; o medo de se falar de sexo e aguçar os(as) jovens para seu exercício (CERQUEIRA, 2012).

Em vista disso, como indica Andreia dos Santos Barreto Monsores de Assumpção (2012), fica nítida a desarmonia entre o sistema legislativo - que reconhece a escola como um dos espaços propícios para a formação de valores -, a produção de conhecimentos - que se efetiva longe do cotidiano escolar - e a atuação docente, visto que os(as) professores(as)/ cursistas se sentem aflitos(as) quando falam da inexistência de instrumentos para realizar tal tarefa. Todo esse cenário leva os(as) professores(as), como afirma a autora, a conclamarem por mais programas de formação docente e por espaços de discussão na escola.

Outro elemento a destacar e que igualmente pode acarretar dificuldades e obstáculos quanto à efetivação de uma política pública de educação para a diversidade é o distanciamento entre aqueles(as) que estão na organização/execução do curso e os(as) cursistas, já que o lugar ocupado pelos(as) primeiros(as) é o de produtores(as) de conhecimento, ao passo que os(as) segundos(as) ocupam os espaços da falta de conhecimento. Nesse âmbito, enquanto a equipe do GDE se firma na posição de especialistas de um determinado saber, os(as) cursistas habitam o lugar de aplicadores de teorias, o que, segundo Eliana Teresinha Quartiero (2014), consiste em uma forma de demarcar e segregar aqueles(as) que lutam por um mesmo propósito, ou seja, por uma educação igualitária. Diante disso, para além das discussões acerca dos efeitos do GDE na prática docente, é preciso destacar a importância de pensarmos nossa relação com o outro:

Consideramos como mais importante uma reformulação das relações com os outros na pedagogia, nesse sentido, não partiríamos das classificações de sujeitos a serem trabalhados, acolhidos ou atendidos. Porém, construir espaços para formação/transformação, distante de saber sobre o outro, além do discurso racional sobre o outro, seria criar espaços de relação com o outro (QUARTIERO, 2014, p. 170).

Toda essa discussão nos leva a pensar na importância de se reconhecer e considerar a história de vida dos(as) professores(as). É preciso olhar para tais histórias, 
como destaca Sirlene Mota Pinheiro da Silva (2015), e identificar as influências da religião na percepção da sexualidade (por vezes, vista como pecaminosa, profana ou proibida), as dúvidas, as incertezas, as permanências e as rupturas que envolvem a sexualidade e as relações de gênero, para assim entendermos os limites quanto à efetivação de uma política pública educacional que valorize a diversidade sexual.

É justamente nesse contexto que, segundo Osmar Arruda Garcia (2015), os processos pelos quais os(as) professores(as) passam para absorver os conhecimentos sobre sexualidade e relações de gênero são marcados por pausas, retrocessos e avanços. Tal prerrogativa indica, portanto, um caráter contraditório na consolidação e na (re)elaboração dos conceitos e valores relacionados a essas temáticas, uma vez que envolvem questões pessoais, reflexões acerca das concepções iniciais, preocupações com a atuação docente, qualificação profissional e compromisso político em relação à valorização da diversidade sexual e de gênero.

Por conta de o GDE ser uma política pública educacional voltada para a desconstrução de valores tradicionais sobre sexualidade e gênero, Zilene Moreira Pereira (2014) reitera que a sensibilização das pessoas quanto aos preconceitos e às discriminações que envolvem essas temáticas não se dá em um curto espaço de tempo. Tendo isso em vista, a autora fala em uma proposta permanente de discussão da sexualidade e das relações de gênero que vá desde o ensino formal até os cursos superiores, além da necessidade de mais propostas de formação no âmbito do desenvolvimento profissional docente referentes a tais temáticas. Entretanto, os trabalhos analisados também destacam a importância da escola como um dos lugares onde se constroem e se reconstroem os processos de socialização referentes à sexualidade e às relações de gênero, bem como o uso das políticas públicas de educação para a manutenção e/ou mudança de valores nas propostas de formação docente. A partir desse cenário, alguns estudos ressaltam a relevância do GDE como política voltada para a valorização da diversidade sexual, a presença da sexualidade e das relações de gênero na escola e do(a) educador(a) para a transformação da realidade social, principalmente no que tange à desmistificação de preconceitos (MOSTAFA, 2009; ASSUMPÇÃO, 2012; SILVA, 2013; SAMPAIO, 2014; GARCIA, 2015).

Em virtude do exposto, Andreia dos Santos Barreto Monsores de Assumpção (2012) faz uma boa síntese ao constatar que, de certa forma, o GDE provocou um 
desencaixe nas percepções sobre diversidade sexual e de gênero e relações étnicoraciais dos(as) professores(as) cursistas, pois "foi recorrente nos memoriais a percepção de 'outro olhar' para a diversidade presente na escola, como uma possibilidade de encarar as relações sociais com maior espírito crítico” (ASSUMPÇÃO, 2012, p. 139). Tal movimento de desencaixe, na análise da autora, só foi possível a partir da aprendizagem do caráter social atribuído às categorias de gênero, sexualidade e raça/etnia enfatizadas durante o curso GDE.

Na mesma perspectiva, Maria das Dores Sampaio (2014) pondera que o GDE funcionou como um despertador nas concepções sobre diversidade sexual e de gênero e relações étnico-raciais dos(as) professores(as) cursistas. Em outras palavras, em seus relatos, os(as) docentes confirmam que o material didático, bem como as discussões proporcionadas nos fóruns do curso, levaram-nos(as) a refletirem sobre sua própria prática pedagógica.

Ainda seguindo a mesma lógica, Rosilene Souza Gomes de Cerqueira (2012) menciona o caráter desestabilizador do curso, visto que participar do GDE provocou dúvidas e desestabilizou certezas dos(as) docentes quanto às temáticas abordadas. Por conseguinte, a autora mostra, ao longo das discussões ocorridas nos fóruns e nos memoriais, as reflexões feitas pelos(as) professores(as), a problematização de conceitos arraigados na formação pessoal, o reconhecimento do preconceito e até mesmo a ampliação do olhar sobre concepções em torno das temáticas da sexualidade e das relações de gênero.

Leandro Veloso Silva (2013), por sua vez, assinala redimensionamentos das aprendizagens, as quais vão desde as trocas de experiências até a possibilidade de repensar as diferenças que fazem parte do sujeito. Conforme analisa Silva (2013), as reflexões, interações e mediações $\operatorname{dos}($ as) professores(as) na plataforma online revelam verdades descontruídas e repensadas, processo de aprendizagem que o autor classifica como momentos de inflexões, isto é, de modificação e de transformação do conhecimento.

As dissertações e teses aqui agrupadas evidenciam que o curso GDE já foi bastante investigado como tema de pesquisa. Há de se considerar também que a maior parte desses trabalhos se centra no estudo das defasagens e das contribuições dessa 
formação no âmbito do desenvolvimento profissional docente na perspectiva de gênero e sexualidade. Além disso, um fator recorrente na leitura desses trabalhos foi que, apesar das provocações e reflexões em torno das temáticas abordadas, os(as) autores(as) mencionam a presença de dificuldades e entraves, seja na implementação, na realização ou na prática docente após o curso.

Tais dificuldades e entraves quanto à efetividade do aprendizado dos(as) professores(as) no GDE levam-nos, como proponho nesta tese, a pensar na força dos processos de socialização. Partindo do pressuposto de que as identidades sexuais são construções sociais decorrentes de um processo em que as referências institucionais e a biografia dos sujeitos se articulam, não é possível negligenciar os processos de socialização na aposta de uma política pública educacional que vise à desconstrução de valores tradicionais de sexualidade e gênero, visto que não se desconstroem os estereótipos de mulher, homem, professora e professor do dia para a noite, ou em uma formação curta via $\mathrm{EaD}$, por exemplo.

É justamente tendo em vista a importância de se considerar a relação entre indivíduo e sociedade que passo agora à apresentação do curso Gênero e Diversidade na Escola (GDE) ofertado no ano de 2009 na cidade de Rio Claro (SP), lócus em que ocorreram as interações sociais das professoras integrantes desta pesquisa com o material do curso.

\subsection{O curso Gênero e Diversidade na Escola (GDE) da UNESP de Rio Claro}

No caso da presente investigação, o curso GDE enfatizado é o da Universidade Estadual Paulista "Júlio de Mesquita Filho" (UNESP), campus de Rio Claro, universidade que foi contemplada pelo edital do MEC no ano de 2009. A responsável pela elaboração da proposta e pela coordenação do curso foi a Profa. Dra. Célia Regina Rossi, coordenadora do Grupo de Pesquisa e Extensão sobre Sexualidade (GSEXs), sediado no Departamento de Educação do Instituto de Biociências da referida universidade. Há de se destacar aqui que o GDE oferecido pela UNESP de Rio Claro possui diferenças em relação ao projeto-piloto, por exemplo, quanto ao tipo de plataforma online utilizada e à distribuição das 200 horas em atividades. 
Tal como relatam Fabiana Marques Costa, Maria Teresa Lima e Célia Regina Rossi (2009), o GDE contou com uma equipe formada por tutores(as) a distância e tutores(as) presenciais, coordenação de tutores(a), professor(a) de Educação a Distância, suporte $\mathrm{EaD}$ e professores(as) pesquisadores(as), sendo estes(as) últimos(as) responsáveis por cada módulo oferecido. Os profissionais foram escolhidos pela coordenação geral por meio de processo seletivo (COSTA; LIMA; ROSSI, 2009).

O GDE da UNESP de Rio Claro teve como público prioritário os(as) professores(as) da rede municipal de ensino, bem como os(as) educadores(as) que trabalham no Centro de Referência de Atendimento à Mulher (CRAM) dos municípios de Botucatu, São José do Rio Preto, Araras, Jaú, Santa Isabel, Matão, Viradouro, Votuporanga e Guaíra (COSTA; LIMA; ROSSI, 2009).

Cada curso recebia, aproximadamente, 60 cursistas, os quais eram divididos em duas turmas. Cada turma ficava sob a responsabilidade de um(a) tutor(a) a distância, o(a) qual orientava, por meio da plataforma Moodle, os(as) professores(as) quanto ao conteúdo, bem como suscitava debates nos fóruns de discussão, tirava dúvidas pelo chat e corrigia as atividades. Já o(a) tutor(a) presencial estimulava e auxiliava os(as) cursistas no manuseio do ambiente virtual e no cumprimento de tarefas.

O curso de Rio Claro foi estruturado em 200 horas, o que equivale a três meses de trabalho com os(as) professores(as). As 200 horas foram divididas em 24 horas presenciais e 176 horas de ensino no Ambiente Virtual de Aprendizagem (AVA). O curso foi organizado em módulos, os quais foram subdivididos em unidades (COSTA; LIMA; ROSSI, 2009). Observemos sua estrutura no quadro abaixo:

Quadro 1: Cronograma e carga horária do curso Gênero e Diversidade na Escola (GDE)

\begin{tabular}{|l|c|}
\hline Aula presencial (Inaugural) & 8 horas \\
\hline Diversidade & 24 horas \\
\hline Gênero & 40 horas \\
\hline Aula presencial & 08 horas \\
\hline Sexualidade e orientação sexual & 40 horas \\
\hline Relações étnico-raciais & 40 horas \\
\hline
\end{tabular}




\begin{tabular}{|l|c|}
\hline Aula presencial & 08 horas \\
\hline Avaliação (Trabalho final) & 32 horas \\
\hline TOTAL & 200 horas \\
\hline
\end{tabular}

Fonte: COSTA; LIMA; ROSSI, 2009.

Sérgio Carrara et al. (2011) descrevem a intenção de cada módulo para a formação dos(as) professores(as). Segundo os autores, o módulo 1, sobre diversidade, embasa todo o curso GDE, pois, ao discutir conceitos como cultura, diversidade cultural e etnocentrismo, bem como suas relações com gênero, sexualidade e raça/etnia, enfatiza a construção de comportamentos e identidades sociais que se dão conforme o espaço e o tempo históricos em que homens e mulheres vivem. Desse processo temos, portanto, a formação de diversas culturas que, por sua vez, contestam padrões observados em sociedade. Assim, ao trabalhar o tema diversidade com professores(as), o objetivo é levá-los(as)

[...] a refletir sobre a organização do ambiente escolar, as relações que se estabelecem nesse espaço e o tipo de material didático que utiliza em face das representações sobre as relações de gênero, raça/etnia, orientação sexual/sexualidade correntes na sociedade brasileira (CARRARA et al., 2011, p. 41).

Já o módulo 2 aborda o gênero e as relações de desigualdade construídas a partir das categorias sociais homem e mulher. Para Carrara et al. (2011), a prioridade desse módulo é evidenciar a construção das identidades de gênero, a qual, além de distribuir estereótipos ao masculino e feminino, resulta em

[...] representações de gênero incidem na socialização infantil e adolescente, nas escolhas que homens e mulheres fazem ao longo da vida, desde a profissão até a vida afetivo-sexual, na construção da identidade social de cada indivíduo, na divisão sexual do trabalho e, finalmente, na organização social da vida privada (CARRARA et al., 2011, p. 41).

Nessa perspectiva, ao priorizar a discussão do gênero como categoria construída socialmente, o módulo 2 conduz o(a) professor(a) à reflexão de que as representações sociais que se atribuem a homens e mulheres podem ser modificadas. Conforme 
destacam os autores, o(a) professor(a) é orientado(a) a pensar criticamente sobre: a articulação entre gênero, sexualidade e raça/etnia, bem como todos os preconceitos e as discriminações que resultam dessa articulação; os movimentos sociais, entre os quais se destacam o feminista, o de mulheres negras e indígenas, o GLBT (Lésbicas, Gays, Bissexuais, Travestis, Transexuais); a violência de gênero, seja ela física, sexual ou psicológica; e, sobretudo, as “formas de discriminação nas práticas docentes, nas atividades didáticas e nos conteúdos curriculares que reforçam as diferenças sociais entre homens e mulheres, tratando-as como se fossem naturais" (CARRARA et al., 2011, p. 42).

O módulo 3, sobre sexualidade e orientação sexual, reforça a sexualidade como construção social. Partindo desse pressuposto, de acordo com Carrara et al. (2011), procura-se desmistificar a sexualidade como unidade biológica e natural, conduzindo o(a) professor(a) a pensar as relações que a instância sexual mantém com os aspectos culturais, sociais, históricos, políticos, além de sua intersecção com outras categorias, tais como classe, raça/etnia, gênero e geração.

A partir dessas considerações, o terceiro módulo do curso promove reflexões acerca da forma como a sexualidade foi e é afirmada e negada na cultura ocidental, processo que resulta no conflito entre a heterossexualidade, considerada como norma, e a homossexualidade, certificada como fora da norma. Em vista disso,

[...] tal conteúdo abordou as normas sociais, neste caso, a "heteronormatividade", como roteiros ou mapas que orientam as condutas e as percepções de si, sem serem, portanto, totalmente coerentes e sem contradições. Pois, no seio de uma organização social, é possível existir um padrão sexual dominante e muitas experiências que fujam à norma. Daí surge a luta constante em torno do que é tido como moralmente certo, normal, legítimo em termos de sexualidade e gênero, além de uma hierarquização sexual na qual a heterossexualidade é considerada "saudável" à custa da estigmatização, da degradação e mesmo da criminalização da homossexualidade. Como frutos dessa hierarquia, surgem atitudes - como é o caso da homofobia - discriminatórias contra a sexualidade considerada desviante (CARRARA et al., 2011, p. 42).

Os autores lembram que esse módulo também levanta a importância da escola no que se refere à educação sexual, uma vez que tal instituição trataria a sexualidade somente a partir da perspectiva biológica, deixando o tema a cargo dos(as) 
professores(as) de ciências e educação física. Exclui-se, dessa forma, a possibilidade de pensar a sexualidade como um fenômeno multifacetado e sujeito às oscilações culturais.

Para a superação dessa abordagem no âmbito escolar, ressalta-se a importância de se levar em conta experiências e percepções juvenis sobre temas como diversidade sexual, direitos sexuais e reprodutivos, gravidez, desejo, prazer, afeto, Aids e drogas (CARRARA et al., 2011, p. 44).

Por fim, o módulo 4, ao abordar os conceitos de raça, racismo e etnicidade, promove reflexões a respeito

[...] da desigualdade racial e de sua manutenção pela força do preconceito e da discriminação; da dinâmica das relações raciais e étnicas; dos diferentes sistemas de classificações raciais e a produção do racismo; dos arranjos possíveis entre raça, gênero e sexualidade na vida social; do impacto das desigualdades étnico-raciais no currículo escolar; por fim, da importância de se criticarem visões estereotipadas na prática do ensino (CARRARA et al., 2011, p. 45).

De acordo com a explicação de Carrara et al. (2011), nesse módulo são apresentadas as teorias raciais dos séculos XIX e XX e as ideias delas decorrentes, a exemplo da miscigenação e do processo de branqueamento. Além disso, discutem-se a presença ou não de uma democracia racial no Brasil, a articulação da raça/etnicidade com o gênero e a sexualidade, bem como as diversas formas de discriminação que surgem a partir dessa articulação e as limitações que o estereótipo pode proporcionar à vida dos sujeitos.

Com base em tais reflexões, o módulo 4 ressalta a existência do racismo, da homofobia e do sexismo nos diversos segmentos da sociedade, o que inclui a escola. Em se tratando dessa instituição, o quarto módulo evidencia, portanto, a presença do preconceito e da discriminação não só nas práticas cotidianas escolares, mas, principalmente, nas políticas educacionais e nos livros didáticos. No entanto, essa observação não descarta a importância da escola no combate à discriminação:

A proposta não é somente apontar como a escola, por meio de seus conteúdos curriculares, pode produzir e reproduzir desigualdades, e sim como ela pode ser transformadora, tornando-se um espaço privilegiado para a promoção da equidade e para a eliminação de toda forma de discriminação e racismo (CARRARA et al., 2011, p. 46). 
Para a aprendizagem dos referidos temas, a metodologia utilizada no GDE se alicerça na perspectiva construtivista interacionista, ou seja, parte do pressuposto de que o(a) cursista é o(a) agente de sua própria aprendizagem, uma vez que está em constante interação com outros(as) alunos(as) e também com o(a) professor(a). Devemos destacar que, na perspectiva construtivista interacionista, os(as) tutores(as) exercem o papel de mediadores(as), auxiliando o(a) cursista no processo de construção do conhecimento ${ }^{11}$ (COSTA; LIMA; ROSSI, 2009).

O curso se desenvolveu em Ambientes Virtuais de Aprendizagem (AVAs), também denominados plataformas (softwares). Segundo Lynn Alves (2009, p. 188), em tais plataformas podem ser encontradas ferramentas que permitem a comunicação entre os sujeitos, o que faz dos AVAs "espaços para a construção de diferentes aprendizagens, tanto em cursos on-line, como mediando as atividades presenciais".

A plataforma utilizada no GDE foi o Moodle. Luís Valente, Paulo Moreira e Paulo Dias (2009) explicam que a palavra, de origem inglesa, significa modular, o que, de certa forma, vai ao encontro do modelo que se enfatiza no curso: o construtivista. Conforme esses autores, o Moodle apresenta as seguintes ferramentas:

- fóruns de discussão configuráveis, ainda que de forma limitada;

- gestão de conteúdos, permitindo a edição direta de documentos em formato texto e HTML (HyperText Markup Language);

- criação de questionários com possibilidade de opção por vários tipos de resposta;

- sistema de Chat com registro de histórico configurável;

- sistema de Blogues;

- editor Wiki;

- sistema de distribuição de inquéritos estandardizados;

- sistema de gestão de tarefas dos utilizadores, etc. (VALENTE; MOREIRA; DIAS, 2009, p. 44).

Para Lynn Alves (2009), a plataforma permite dois tipos de diálogos. A primeira comunicação é chamada de síncrona, “isto é, em tempo real, através dos softwares de

11 Em relação à perspectiva construtivista interacionista utilizada na plataforma Moodle, Valente, Moreira e Dias (2009, p. 41) explicam: "Os ambientes de aprendizagem considerados construtivistas preconizam que o aluno participe ativamente na resolução de problemas, que utilize o pensamento crítico sobre as atividades de aprendizagem que mais significam para si e que construa o seu próprio conhecimento, cabendo ao professor o papel de 'parteiro' no processo de nascimento da compreensão e de orientador, facilitador, conselheiro, tutor e aprendiz". 
comunicação instantânea" (ALVES, 2009, p. 189); nela se enquadram os chats (batepapo), o Skype e as videoconferências. Já a segunda forma de comunicação é assíncrona, a qual "efetiva e garante a comunicação em momentos distintos sem a presença dos sujeitos, isto é, existe uma diferença entre o tempo em que foi enviada a mensagem que será recebida" (ALVES, 2009, p. 189). Nesse tipo de diálogo, podemos considerar os fóruns de discussão, os diários, as tarefas, a escrita colaborativa (wiki), o glossário e o perfil.

Ao final do curso, o(a) aluno(a) foi avaliado pelos(as) tutores(as) a distância e presenciais com base em sua participação na plataforma, ou seja, em seu engajamento apresentando em discussões dos fóruns, chats e postagens de dúvidas e tarefas. Além dessa avaliação, ao final do módulo 5 - justamente denominado Avaliação - foi realizada uma autoavaliação do(a) cursista, bem como o trabalho final, que consistiu na elaboração de um projeto que pudesse ser desenvolvido na escola e que versasse sobre um dos temas em pauta: sexualidade, relações de gênero ou raça/etnia. Além disso, o(a) cursista foi solicitado a entregar um memorial, entendido como um relato das suas experiências individuais durante o curso. Após a totalização das 200 horas, o(a) professor(a) recebeu um certificado de extensão (COSTA; LIMA; ROSSI, 2009).

Devemos destacar que cada município ofereceu um espaço apropriado, com disponibilidade de computadores para o(a) tutor(a) presencial orientar os(as) professores(as) nas tarefas. Foi nesses espaços que, em geral, ocorreram os encontros presenciais com os(as) tutores(as) a distância.

Partindo do pressuposto de que o GDE foi destinado a professores(as), independentemente do sexo, um fato interessante a mencionar é o grande número de mulheres que participaram do curso ministrado pela UNESP de Rio Claro, tanto na primeira quanto na segunda oferta. Observemos as tabelas a seguir: 
Quadro 2: Qual é o seu sexo?

\begin{tabular}{|c|c|c|}
\hline Ofertas GDE & $\mathbf{1}^{\mathbf{a}} \boldsymbol{-} \mathbf{j u n h o} / \mathbf{2 0 0 9}$ & $\mathbf{2}^{\mathbf{a}}-\mathbf{n o v e m b r o / 2 0 0 9}$ \\
\hline Feminino & 376 & 397 \\
\hline Masculino & 29 & 18 \\
\hline Total & 405 & 415 \\
\hline
\end{tabular}

Fonte: Disponível em: <https://sites.google.com/site/gdeunesp/>.

Em relação aos(as) cursistas que participaram da primeira e da segunda oferta em São José do Rio Preto, cidade em que fui tutora a distância e onde se encontram os sujeitos dessa pesquisa, constatamos que a presença feminina também é maior:

Quadro 3: Alunos(as) aprovados(as)

\begin{tabular}{|c|c|c|}
\hline $\begin{array}{c}\text { Ofertas GDE } \\
\text { (Polo de São José do Rio Preto) }\end{array}$ & $\mathbf{1}^{\mathbf{a}} \boldsymbol{-}$ junho/2009 & $\mathbf{2}^{\mathbf{a}}$ - novembro/2009 \\
\hline Feminino & 55 & 52 \\
\hline Masculino & 4 & 2 \\
\hline Total & 59 & 54 \\
\hline
\end{tabular}

Fonte: Disponível em: <https://sites.google.com/site/gdeunesp/>.

Esses dados nos levam a considerar a massiva presença das mulheres na educação escolar, participação feminina, aliás, perceptível também em âmbito mundial (APPLE, 1995). Como fenômeno histórico, o processo de feminização do magistério tem início durante o século XIX e está ligado, conforme explica Cláudia Vianna (2002), às transformações que ocorreram no mundo do trabalho, as quais provocaram a intensificação da presença das mulheres na oferta e na procura de emprego, a divisão sexual do trabalho e a feminização de algumas profissões, a exemplo da docência.

No caso do magistério brasileiro, expõe Guacira Lopes Louro (2001), o ideal republicano (século XIX) começa a ver na educação a chance de modernização do país. 
O grande número de analfabetos(as) nas províncias fomentava discussões na política, na mídia impressa (jornais) e em saraus, afinal, "os anos passavam, o Brasil caminhava para o século XX e, nas cidades e povoados, sem falar na imensidão rural, grande parte da população continuava analfabeta" (LOURO, 2001, p. 444).

A preocupação em saber ler e escrever, bem como em ter conhecimento das quatro operações, levou, em 1827, os legisladores a incentivarem a criação de escolas. No entanto, tal como afirma Louro (2001), o referido projeto não encontrou respaldo na sociedade escravocrata e coronelista da época, ficando o ideal de modernização restrito às poucas escolas que existiam.

A autora assinala que as escolas para meninos eram diferentes das escolas para meninas. Consequentemente, o tipo de educação também era distinto: enquanto se educava o menino para o espaço público, a educação da menina centrava-se em sua atuação como esposa e mãe no espaço privado - em outras palavras, no lar.

A educação da mulher seria feita, portanto, para além dela, já que sua justificativa não se encontrava em seus projetos, anseios ou necessidades, mas em sua função de educação dos filhos ou, na linguagem republicana, na função de formadora dos futuros cidadãos (LOURO, 2001, p. 447).

Também segundo Louro (2001), nas últimas décadas do século XIX, a educação das mulheres começa a sofrer algumas modificações. Com a modernização da sociedade e o surgimento de novas ocupações para os homens, o magistério, até então ocupado majoritariamente por homens, torna-se trabalho de mulher. Assim, a aproximação dos homens a atividades de maior rentabilidade econômica inicia o processo de feminização do magistério, fenômeno que causou certas polêmicas.

Louro (2001) reitera, ainda, que as discussões sobre a feminização do magistério giravam em torno da incredulidade, para aqueles que viam as mulheres como intelectualmente inferiores aos homens para educarem crianças, e da vocação, posição defendida por aqueles que consideravam que as mulheres, por gerarem as crianças, eram educadoras natas. O discurso que prevaleceu foi o último, legitimando, além da saída dos homens da docência, a ideia do magistério "como uma atividade de amor, de 
entrega e doação. A ele acorreriam aquelas que tivessem "vocação"” (LOURO, 2001, p. $450)$.

O magistério passa a ser uma agência de produção de professoras, tal como argumenta a autora. Evidencia-se, então, uma grande preocupação com a formação da futura professora, visto que, para educar crianças, as docentes deveriam ter uma boa formação moral. Nesse contexto:

Sem dúvida a responsabilidade de "manter-se acima do comportamento comum" representou um encargo social e teve profundos efeitos sobre as vidas de mestres e mestras. Para bem poder exercer o papel de modelo para as crianças e jovens, eles se viram obrigados a um estrito controle sobre seus desejos, suas falas, seus gestos e atitudes e tinham na comunidade o fiscal e censor de suas ações (LOURO, 2001, p. $462-$ 463).

Em outra publicação, Louro (1989) descreve como o fenômeno de feminização do magistério se prolongou nas décadas seguintes do século $\mathrm{XX}$, ora incorporando novas exigências para o exercício da docência, ora lutando por reivindicações no que concerne a melhorias na profissão, já que, ao longo dos anos, o magistério foi perdendo seu status e prestígio. Como esclarece a autora, com a ampliação do mercado de trabalho para as mulheres, o magistério, antes cursado por moças de classe média, passa a ser alvo das moças de classe baixa, por ser uma opção de trabalho mais acessível. Entretanto, a vocação e a associação da figura da professora à da mãe continuariam proeminentes no ato de lecionar.

A grande presença das mulheres na docência é um fenômeno histórico que pode ser notado até hoje: basta observarmos o grande contingente de mulheres participantes nas ofertas do curso GDE. Assim, analisar a participação de professoras no curso, pela perspectiva das relações de gênero, pode ser revelador do processo de feminização do magistério e de suas implicações para a figura docente. Como assevera Vianna (2013, p. 167), a "utilização do conceito de gênero, como uma categoria explicativa de análise, possibilita a compreensão dos elementos tradicionalmente associados às desigualdades que definem a condição feminina”.

Nesse sentido, a investigação dos relatos de professoras durante o curso sobre os distintos significados e sentidos de ser mulher e ser professora nos leva a questionar 
sobre o quanto a educação voltada para a formação docente em sexualidade e gênero consegue, em certa medida, problematizar os preconceitos advindos da lógica heteronormativa presente, de maneira tão intensa, em nossa sociedade. Ademais, faznos pensar também - caso o curso tenha provocado algum tipo de alteração - no modo como tais professoras relatam o processo; em caso negativo, somos levados a interrogar quais foram ou são os obstáculos que dificultam a abordagem da sexualidade na perspectiva de gênero na escola. É pertinente, portanto, verificar se as professoras que passam pelo GDE experimentam algum tipo de alteração em sua apreensão da sexualidade e das relações de gênero que pautam suas concepções sobre ser mulher e ser professora.

A análise da participação de professoras no referido curso a partir do olhar de gênero teve por intenção revelar dimensões da docência e da própria figura docente. Afinal, como elas definiam o que era ser mulher e ser professora quando ingressaram no curso? Ser mulher e ser professora se confundiam? E hoje, depois do GDE, houve alterações em tais concepções? Como se veem? Como veem as relações de gênero e as manifestações de sexualidade em sala de aula após a participação no curso?

Investigar essa temática é tarefa importante, já que entender como a sexualidade e as relações de gênero são recebidas e apreendidas em um curso de formação no âmbito do desenvolvimento profissional docente pode fornecer-nos indícios para compreender o peso dessa iniciativa na formação de professores(as), além de proporcionar discussões capazes de enfrentar preconceitos e impulsionar ações referentes à equidade de gênero em educação escolar. 


\section{COMO NASCE A PESQUISA}

Todo ponto de vista é a vista de um ponto.

LEONARDO BOFF

(A águia e a galinha)

Uma vez delineados os objetivos deste trabalho, a partir de agora fundamento a escolha da abordagem metodológica, defino os sujeitos da pesquisa, relato a entrada em campo e descrevo o modo como analisei os resultados. É justamente no esclarecimento do caminho metodológico que evidencio meu olhar sobre os dados, a maneira como os organizei e propus sua análise para, então, apresentar o entendimento dos significados sobre ser mulher e ser professora para um grupo de docentes participantes do curso Gênero e Diversidade na Escola (GDE).

\subsection{A abordagem metodológica}

A tarefa da metodologia é evidenciar, bem como discutir, de maneira crítica, os caminhos da investigação científica. A primeira discussão a ser feita a esse respeito refere-se à escolha da abordagem utilizada. No caso da presente pesquisa, a opção foi pela metodologia qualitativa, já que esta privilegia,

[...] de modo geral, a análise de microprocessos, através de estudo das ações individuais e grupais. Realizando um estudo intensivo dos dados, tanto em amplitude quanto em profundidade, os métodos qualitativos tratam as unidades sociais investigadas que desafiam o pesquisador. Neste caso, a preocupação básica do cientista social é a estreita aproximação dos dados, de fazê-lo falar da forma mais completa possível, abrindo-se à realidade social para melhor apreendê-la e compreendê-la (MARTINS, 2004, p. 292).

Entendo que a abordagem qualitativa era a mais interessante para este trabalho, pois sua apreensão profunda da realidade permite ao(à) pesquisador(a) chegar a uma maior compreensão dos significados, implícitos e explícitos, da realidade social examinada. Assim, o uso de tal metodologia contribuiria para uma maior apreensão dos distintos significados de ser mulher e ser professora pela ótica das relações de gênero. 
Diante da escolha de uma abordagem qualitativa, a construção do marco conceitual torna-se fundamental, afinal, quando se utiliza essa abordagem, a investigação passa a depender da competência teórica e metodológica do cientista social (MARTINS, 2004). Em outras palavras, a teoria, ao lado da intuição do(a) pesquisador(a), transforma-se em uma valiosa ferramenta para a interpretação dos dados.

Nesse sentido, destaco que os referenciais teóricos desta pesquisa são os estudos de Michel Foucault (1985) e os Estudos Feministas, incluindo as(os) teóricas(os) que partem de uma perspectiva do gênero como categoria de análise histórica.

Os estudos de Foucault sobre a sexualidade como uma construção histórica mediada pela produção de saberes (discursos) e por relações de poder dialoga com os Estudos Feministas, que consideram o gênero como um elemento histórico. Para Joan Scott (1995), autora representante dessa tendência, a historicidade do gênero nos permite enxergar as relações de poder que envolvem e engendram a construção de masculinidades e feminilidades, determinando modos de ser para homens e mulheres.

Lucila Scavone (2008), na mesma direção, ressalta que o olhar de gênero é uma ferramenta valiosa para superar as explicações simplistas que envolvem homens e mulheres no âmbito das instâncias e práticas culturais. Na defesa de uma sociologia ou teoria feminista, a autora argumenta que "foi esse olhar que deu visibilidade às relações de dominação e poder que divide o mundo social em gêneros e que questionaram uma ordem sexual tida como natural" (SCAVONE, 2008, p. 178).

A categoria de gênero, assim, é um rico suporte para análises no campo educacional, sobretudo quando consideramos que grande parte do corpo docente é composta de mulheres. A utilização de tal conceito, como mostra Cláudia Vianna (2003), ao trazer à tona as desigualdades acerca da condição feminina, auxilia na compreensão "dos significados de gênero que marcam as relações escolares, as identidades e práticas docentes" (VIANNA, 2013, p. 167).

Há de se destacar, portanto, a grande importância do pensamento feminista para a presente pesquisa, pois a articulação do conceito de gênero, como categoria de análise histórica (SCOTT, 1995), com os dados permitirá questionar papéis e ações vinculadas ao sujeito feminino. De acordo com as palavras de Marlise Matos (2008, p. 349-350): 
O aporte e a contribuição do campo de gênero feminista é declarar a infinita capacidade humana (portanto, igualmente feminina e masculina, é sempre prudente anunciar) de interpretar, de re-colocar, e re-significar permanentemente os conteúdos e as formas daquilo que se apresenta como contingentemente universal, ciências em permanente devir, no deslizamento da norma hierárquica, na constante problematização das hierarquias e das subordinações, na crítica contumaz às opressões de todas as ordens, enfim, na e pela transgressão multicultural emancipatória como método.

Nesse sentido, os estudos de Foucault e do pensamento feminista, bem como de outros(as) autores(as) que partilham de tais perspectivas, foram fundamentais para o desenvolvimento desta investigação.

\subsection{As mulheres-professoras e a cidade de São José do Rio Preto (SP)}

As professoras de Educação Básica (Ensino Fundamental) da rede municipal de São José do Rio Preto (SP) que participaram da primeira (junho de 2009) e da segunda oferta (novembro de 2009) do curso GDE compõem o eixo-central desta pesquisa.

É importante destacar que a participação no curso, segundo os critérios da Prefeitura de São José do Rio Preto, foi voluntária. No entanto, as docentes que concluíam o curso, ao apresentarem o certificado de aprovação, aumentavam sua classificação na rede municipal de educação, o que facilita o processo de escolha de classes e de remoção entre as escolas da rede municipal: aquele(a) que tem maior pontuação escolhe em primeiro lugar.

A opção pela cidade de São José do Rio Preto deu-se pelo fato de eu ter sido tutora a distância desse polo no ano de 2009. Durante cada oferta do curso houve três encontros presenciais, o que me proporcionou conhecer, ainda que de forma rápida, as professoras cursistas, suas dúvidas, suas aflições, alguns de seus preconceitos e sua vontade de aprender sobre essas temáticas.

Cada polo era dividido em duas turmas: A e B. Embora nos encontros presenciais eu tenha trabalhado com as professoras das duas turmas, por uma questão ética de pesquisa, elegi investigar somente as professoras da turma A, justamente o grupo em que não fui tutora oficial e com o qual, portanto, não tive um contato direto na plataforma Moodle. Como examinarei somente os registros referentes aos módulos 2 
(Gênero) e 3 (Sexualidade e Orientação Sexual), ressalto que o número contabilizado de professoras da turma A foi seis.

Em relação a São José do Rio Preto, local onde vivem os sujeitos desta pesquisa, trata-se de um município situado no Norte do Estado de São Paulo e que, segundo o Instituto Brasileiro de Geografia e Estatística (IBGE), possuía, até 2010, uma população de 408.258 habitantes. A cidade foi elevada à categoria de município em 1894, mas a fundação da Vila de São José do Rio Preto data de 1852 e serviu, em um primeiro momento, como pousada e entreposto comercial para tropeiros (GOVERNO DO ESTADO DE SÃO PAULO, 2012).

A chegada de mineiros em 1880, da atividade cafeeira a partir de 1884 e da estrada Araraquarense em 1912 levou infraestrutura ao local, proporcionando crescimento demográfico e desenvolvimento econômico para a cidade. Dessa forma, além da agropecuária e da produção de café, São José do Rio Preto, em 1930, inicia o cultivo de algodão (GOVERNO DO ESTADO DE SÃO PAULO, 2012).

Tais atividades comerciais impulsionaram economicamente essa região, atraindo a instalação de indústrias produtoras de óleo de algodão. O poder econômico derivado da produção diversificada estendeu o processo de industrialização para outros ramos, como móveis, vestuário e produtos de minerais não metálicos (GOVERNO DO ESTADO DE SÃO PAULO, 2012).

A partir desse contexto, a cidade de São José do Rio Preto vem crescendo cada vez mais, pois, ao aliar as riquezas da região aos avanços tecnológicos, transformou-se em polo econômico consolidado e dedica-se hoje, sobretudo, ao mercado externo de produção de laranja e cana de açúcar e à industrialização de móveis, equipamentos médicos hospitalares, joias e alimentos. O munícipio apresenta significativo crescimento de áreas urbanas, possuindo, em sua periferia, loteamentos urbanos ocupados pela população de baixa renda; ao centro, além das atividades comerciais, destaca-se a presença de uma população de maior poder aquisitivo econômico (GOVERNO DO ESTADO DE SÃO PAULO, 2012).

Em termos de crescimento populacional, pode-se observar, como é relatado no Plano Municipal da Educação (2005/2010) com base no Censo Demográfico de 1991 e 2000, uma diminuição da taxa de natalidade na cidade, o que, consequentemente, indica 
um envelhecimento de sua população (PREFEITURA MUNICIPAL DE SÃO JOSÉ DO RIO PRETO, 2005).

Em relação aos aspectos educacionais, a cidade possui expressivo polo educacional, com a presença de instituições de ensino superior tanto particulares, quanto estaduais, a exemplo da Universidade Estadual Paulista "Júlio de Mesquita Filho" (UNESP). Em consulta ao site da Diretoria de Ensino da Região de São José do Rio Preto, verifiquei que, em 2013, o município contava com 9 escolas estaduais, 18 escolas municipais, 32 escolas particulares, 1 escola federal e 2 escolas da Secretaria da Ciência e Tecnologia (DIRETORIA DE ENSINO - REGIÃO DE SÃO JOSÉ DO RIO PRETO, 2013).

Tais dados sobre a cidade de São José do Rio Preto são importantes, uma vez que revelam aspectos econômicos, sociais e culturais da localidade em que os sujeitos desta pesquisa vivem. Há de se considerar, portanto, que essas informações são relevantes para o conhecimento dos distintos significados sobre ser mulher e ser professora das participantes do GDE.

\subsection{Os instrumentos de coleta de dados}

Segundo Heloisa Martins (2004), a abordagem qualitativa permite flexibilidade quanto à escolha das técnicas de coleta de dados. Nesse sentido, com base nos objetivos da pesquisa, optei por realizar, em um primeiro momento, a coleta e a análise dos registros e das atividades das professoras na plataforma Moodle durante os módulos 2 (Gênero) e 3 (Sexualidade e Orientação Sexual), considerando aquelas que optaram por desenvolver projetos referentes a esses temas no módulo 5 (Avaliação).

Em relação à tarefa do quinto módulo, é importante mencionar que a atividade foi utilizada como critério de seleção dos sujeitos da pesquisa, já que esse módulo, além de solicitar uma autoavaliação do(a) cursista - momento em que o(a) aluno(a) avalia sua participação no curso - e um memorial - relato das experiências individuais vividas durante o curso -, ainda propõe a elaboração de um projeto sobre um dos temas trabalhados no curso e que pudesse ser aplicado na Educação Básica. Assim, as atividades referentes aos módulos 2 e 3 do GDE que foram analisadas são aquelas 
produzidas pelas professoras que optaram, no módulo 5, pela elaboração de projetos acerca de relações de gênero ou sexualidade.

Em um primeiro momento, o número de professoras que elaboraram projetos sobre os referidos temas foi 16 , sendo 4 delas da primeira oferta e 12 da segunda oferta do curso. No entanto, em uma análise preliminar de suas atividades dessas professoras, averiguei que algumas participavam de forma permanente em fóruns, atividades e diários, enquanto outras não. A participação efetiva configurou, assim, outro critério de seleção dos sujeitos, o que me levou a reduzir o número de professoras incluídas na pesquisa: entre as 16 iniciais, selecionei 10 , sendo 2 provenientes da primeira oferta e 8 da segunda. Esse número ainda foi novamente reduzido de 10 para 6, fato que explico no item 2.4, a seguir.

Para a coleta desses dados, recorri aos registros das cursistas nas seguintes ferramentas: diários (espaço em que os(as) alunos(as) registraram suas expectativas, angústias, questionamentos e aprendizagens), fóruns de discussão (espaço em que os(as) alunos(as) discutiam as temáticas do curso com o(a) tutor(a) a distância e outros colegas de sua turma) e tarefas (espaço em que os(as) cursistas anexavam as atividades que foram propostas pelo(a) professor(a) do módulo). A análise dessas atividades possibilitou conhecer, em um primeiro momento, quem são as professoras participantes do curso, o que entendem dos temas em pauta, o motivo de terem se inscrito no GDE e o modo como se posicionam diante de tais temáticas quando elas emergem em sala de aula.

Já o segundo instrumento de coleta de dados consistiu na realização de uma entrevista semiestruturada com as professoras, cinco anos após o término do curso. ${ }^{12}$ Conforme explicam Robert Bogdan e Sari Biklen (1994, p. 134), a entrevista equivale a uma "conversa intencional, geralmente entre duas pessoas, embora por vezes possa envolver mais pessoas (Morgan, 1988), dirigida por uma das pessoas, com o objetivo de obter informações sobre a outra".

${ }^{12}$ Em conformidade com as orientações do Comitê de Ética, este trabalho se comprometeu a respeitar a integridade e o anonimato das professoras participantes da pesquisa. 
A utilização da entrevista foi significativa, pois possibilitou levantar aspectos importantes em relação ao conhecimento das professoras entrevistadas, tais como:

[...] dados referentes a fatos; ideias, crenças, maneiras de pensar; opiniões, sentimentos, maneiras de sentir; maneiras de atuar; conduta ou comportamento presente ou futuro; razões conscientes ou inconscientes de determinadas crenças, sentimentos, maneiras de atuar ou comportamentos (JHODA, 1951, p. 152 apud MINAYO, 2000, p. 108).

Em relação ao roteiro a ser seguido, optei pela entrevista semiestruturada, visto que, por possuir certa flexibilidade, esse tipo de entrevista "permite correções, esclarecimentos e adaptações que a torna sobremaneira eficaz na obtenção das informações desejadas" (LUDKE; ANDRÉ, 1986, p. 34). Tal particularidade mostrouse muito valiosa, já que a apreensão das possíveis contribuições do curso para a prática docente foi obtida apenas por meio de relato oral e não de observações da prática docente.

A entrevista foi realizada individualmente, sendo gravada e, posteriormente, transcrita e analisada.

\subsection{A entrada em campo}

Minha entrada em campo se deu em junho de 2014. No entanto, a leitura das atividades, o processo de construção da entrevista semiestruturada, bem como o contato com as professoras participantes do curso antecederam minha ida à cidade de São José do Rio Preto.

Quanto ao roteiro da entrevista, ${ }^{13}$ sua elaboração resultou tanto das leituras acerca do que me propus a investigar - o que inclui o referencial teórico e metodológico -, quanto do material produzido pelas professoras durante o curso, ou seja, suas atividades, reflexões e discussões nos fóruns. Além disso, devo destacar que, devido à flexibilidade que o modelo semiestruturado permite ao(à) entrevistador(a), durante o

\footnotetext{
${ }^{13} \mathrm{O}$ roteiro da entrevista semiestruturada encontra-se apresentado no Apêndice A.
} 
diálogo com as professoras outras questões foram surgindo, permitindo-me tornar a entrevista ainda mais esclarecedora.

Para entrar em contato com as professoras, em abril de 2014 solicitei a ajuda de duas profissionais que atuaram comigo durante as ofertas do curso GDE em junho e novembro de 2009, sendo elas a professora Adriana de Paula Silva, tutora presencial e coordenadora de Departamento da Secretaria de Educação da cidade de São José do Rio Preto, e Fabiana Marques Costa, designer instrucional. A ajuda de ambas foi muito valiosa para a realização da pesquisa, pois foi por meio delas que obtive o e-mail e o telefone das professoras selecionadas.

Em maio de 2014, contatei dez professoras, sendo que oito delas residem em São José do Rio Preto (SP) e duas em Irapuã (SP). O primeiro contato foi feito por telefone, e, em um momento inicial, mesmo após me identificar como pesquisadora, aluna do curso de doutorado da Universidade de São Paulo e explicar do que se tratava a pesquisa, encontrei resistências por parte das docentes em cederem a entrevista, já que imaginavam que a conversa teria um tom avaliativo em relação ao que aprenderam ou não no curso. Esclareci, porém, que a intenção era realizar um diálogo a fim de conhecer os significados, para elas, do que é ser mulher e ser professora e investigar se o curso Gênero e Diversidade na Escola (GDE) possuía algum tipo de influência nessas compreensões.

Naquele primeiro contato, duas professoras disseram que não trabalhavam mais como docentes. Uma delas, por questões pessoais, resolveu abandonar o magistério e se dedicar ao cuidado da filha. A outra, então estudante de doutorado, havia exonerado seu cargo na Prefeitura de São José do Rio Preto após ter sido contemplada com uma bolsa de estudos e, com isso, ter se mudado para outro Estado. Diante desse quadro, optei por não realizar a entrevista com as duas professoras, pois um dos critérios para a seleção dos sujeitos era a atuação na docência, visto que um dos significados e sentidos investigados dizia respeito às diferentes formas de ser professora. 
Em um segundo momento, após o contato por telefone, enviei às oito professoras um e-mail com uma Carta Convite, ${ }^{14}$ na qual me apresentei como pesquisadora, disponibilizei meus contatos e, em seguida, expus os objetivos da pesquisa, assegurando-lhes quanto à utilização ética de relatos e imagens. Após o envio da Carta, solicitei às professoras uma resposta, via e-mail, em que elas se posicionassem sobre suas participações. Das oito docentes contatadas, porém, apenas quatro me responderam, sendo que três concordavam em ceder a entrevista e uma não, pois estava em início de gravidez e alegava estar passando por momentos difíceis.

Já em um terceiro momento, liguei novamente para as sete professoras, o que incluiu as três professoras que não haviam se posicionado por e-mail, a fim de me certificar de sua participação na pesquisa e agendar o dia e o horário das entrevistas. Nesse último contato, uma das professoras que não havia respondido o e-mail negou-se a participar da pesquisa, afirmando que já estava em vias de se aposentar, encontrava-se cansada e, por isso, não poderia ajudar na investigação. Assim, a pesquisa passou a contar com seis professoras.

O quadro 4 apresenta os nomes das professoras, a oferta na qual participaram da primeira edição do GDE que foi oferecido pela UNESP de Rio Claro e o título do projeto elaborado por cada uma delas no módulo 5 do curso.

Quadro 4: Professoras, oferta e título do projeto

\begin{tabular}{|l|c|l|}
\hline Nome da professora & Oferta & Título do projeto \\
\hline Gislaine & $1^{\mathrm{a}}$ & Gênero e sexualidade na escola infantil \\
\hline Celina & $2^{\mathrm{a}}$ & Vamos brincar? Brincar de quê? \\
\hline Helena & $2^{\mathrm{a}}$ & Meu corpo \\
\hline Bianca & $2^{\mathrm{a}}$ & Despertar \\
\hline Carla & $2^{\mathrm{a}}$ & Despertar \\
\hline Maria Rita & $2^{\mathrm{a}}$ & Sexualidade humana \\
\hline
\end{tabular}

${ }^{14}$ A Carta Convite encontra-se apresentada no Apêndice B. 
Fonte: Registros das atividades das professoras na plataforma Moodle.

Em junho de 2014, uma vez confirmada a participação e o consentimento de seis docentes, fui à cidade de São José do Rio Preto e realizei as entrevistas, as quais foram gravadas e, em seguida, transcritas. Durante a coleta de cada relato, procurei observar e anotar os gestos, o tom das falas e a forma de se portar de cada docente. Em alguns casos, as anotações ocorreram durante as entrevistas; em outros, após o relato.

As entrevistas foram realizadas nos dias 13, 14 e 16 de junho de 2014, em períodos variados (manhã, tarde e noite) e nos espaços escolhidos por cada docente (suas casas ou seus locais de trabalho). É válido destacar que fui muito bem acolhida pelas entrevistadas, sendo recebida com bastante simpatia e seriedade para a realização da entrevista.

Cada entrevista durou em torno de uma hora e meia, tendo todas elas se iniciado pela entrega do Termo de Consentimento Livre e Esclarecido, ${ }^{15}$ documento em que ratifico a utilização ética dos relatos. Na tentativa de manter o anonimato das professoras, foram-lhes atribuídos nomes fictícios escolhidos por elas mesmas, exceto no caso de algumas que pediram para que eu mesma lhes atribuísse um nome.

É importante ressaltar que tanto o registro das atividades das professoras na plataforma Moodle, quanto suas falas obtidas por meio da entrevista foram organizados com base nos estudos sobre análise de conteúdo de Laurence Bardin (1977) e Maria Laura Puglisi Barbosa Franco (2008), fundamentação que exponho no próximo item.

\subsection{A forma de análise dos resultados}

A organização dos dados pressupõe sua distribuição em categorias de análise. Tal categorização, como explica Maria Laura Puglisi Barbosa Franco, “é uma operação de classificação de elementos constitutivos de um conjunto, por diferenciação seguida de um reagrupamento baseado em analogias, a partir de critérios definidos" (FRANCO, 2008, p. 59).

\footnotetext{
${ }^{15}$ O Termo de Consentimento Livre e Esclarecido encontra-se apresentado no apêndice C.
} 
Isto posto, durante a elaboração do projeto, bem como ao longo do processo da escrita que originou essa tese, a minha intenção inicial era utilizar como embasamento para a categorização dos dados, o procedimento denominado análise de conteúdo, técnica definida por Laurence Bardin (1977, p. 42) nos seguintes termos:

Um conjunto de técnicas de análise das comunicações, visando obter, por procedimentos, sistemáticos e objetivos de descrição do conteúdo das mensagens, indicadores (quantitativos ou não) que permitam a inferência de conhecimentos relativos às condições de produção/recepção (variáveis inferidas) destas mensagens.

Segundo Franco (2008), a utilização da análise de conteúdo pressupõe a delimitação de unidades de análise, as quais são divididas em unidades de registro e de contexto. Enquanto a unidade de registro "é a menor parte do conteúdo, cuja ocorrência é registrada de acordo com as categorias levantadas" (FRANCO, 2008, p. 41), a unidade de contexto corresponde às circunstâncias em que a unidade de registro foi produzida.

Como consequência dessa escolha, elegi o tema como unidade de registro, uma vez que a análise temática, em se tratando de uma investigação de abordagem qualitativa como essa, pode nos dar maiores esclarecimentos acerca dos significados expressos tanto nos registros das atividades das professoras, quanto em suas falas durante a entrevista.

Com a opção pela análise temática, comecei a examinar, organizar e a categorizar os dados. Todavia, essa técnica pareceu não ser a mais adequada diante do material que eu havia coletado, posto que se tratava de um conjunto de relatos que se tornariam limitados caso fossem organizados em categorias.

Desse modo, me propus a construir o perfil de cada professora a partir de seus relatos, tanto os que foram produzidos na plataforma Moodle, como aqueles que foram fornecidos durante as entrevistas. Na medida em que eu ia lendo, organizando e analisando o material coletado, fui me expropriando, apropriando e reproduzindo algumas falas das docentes, ao modo que, após várias versões, cheguei ao perfil de cada mulher/professora.

Devo destacar ainda que como fonte de inspiração, utilizei os trabalhos de Marília Pinto de Carvalho (1999) e de Edla Eggert (2009), autoras que, ao descreverem 
a narrativa de vida de seus sujeitos, foram elaborando seus perfis e intercalando-os, ao mesmo tempo, com as análises por elas elaboradas. Assim, é com referência a esses trabalhos que procuro, a partir dos perfis das professoras, tecer algumas análises sobre as diferentes formas de ser mulher e ser professora. 


\title{
3. AS MULHERES-PROFESSORAS E UM CURSO
}

\author{
Mulher é desdobrável. Eu sou. \\ ADÉLIA PRADO \\ (Com licença poética)
}

Tendo em vista as definições metodológicas expostas, inicio agora a apresentação das seis docentes, de suas concepções sobre ser mulher e ser professora, bem como suas resistências, inquietações e reflexões durante e após a participação no curso Gênero e Diversidade na Escola (GDE). Para tanto, aponto e exploro os aspectos mais relevantes em torno das diferentes formas de ser mulher e ser professora para, em seguida, discutir alguns desdobramentos.

Antes de dar início à análise, destaco que há certas características comuns à maior parte das entrevistadas, sendo importante fazer menção a elas de forma conjunta: as seis professoras são brancas; vêm de famílias de classe média; são heterossexuais; na ocasião, estavam casadas há mais de dez anos; cinco possuem filhos(as); quatro delas residem em São José do Rio Preto e duas em cidades vizinhas; foram todas criadas na religião católica, embora somente uma seja praticante dessa doutrina nos dias atuais; quatro têm em comum a formação acadêmica em pedagogia, sendo as outras duas graduadas em cursos de licenciatura; lecionam há mais de dez anos; são funcionárias públicas efetivas, sendo cinco delas concursadas pela Prefeitura de São Jose do Rio Preto e uma pelo Estado de São Paulo.

A preocupação no destaque desses pontos está no fato de que tais características indicam aspectos relevantes dos processos de socialização das docentes, aspectos estes que podem inferir nos significados que elas atribuem às diferentes formas de ser mulher e de ser professora. Todavia, é preciso enfatizar que a homogeneidade encontrada não ofusca a presença das diferenças entre as entrevistadas. Há de se considerar, pois, que tanto os aspectos que as aproximam quanto os que as distanciam são significativos em suas construções como mulheres e professoras. 


\subsection{Gislaine: "Eu acho que ser mulher é representar o belo"16}

À época de sua entrevista, Gislaine contava 52 anos de idade. Nascida em Belo Horizonte (MG), mudou-se para São José do Rio Preto (SP) em 1996, após trabalhar na rede particular de ensino de Cuiabá (MT) durante uma década e meia. Efetivou-se na Prefeitura da cidade paulista em 1997, tendo ministrado aulas para o $1^{\circ}$ ano do Ensino Fundamental ao longo de dez anos. Nos últimos cinco, atuava como coordenadora pedagógica do mesmo órgão público.

Em seu currículo, acadêmico, Gislaine reúne o antigo magistério, a graduação em Pedagogia e uma especialização em Psicopedagogia, todos esses cursos efetivados em universidades particulares. Considera-se excelente aluna, pois sempre gostou muito de estudar e, sobretudo, de ler.

Realizada em seu ambiente de trabalho, a entrevista contou com grande receptividade. Sempre solícita e bem-humorada, a entrevistada respondeu às questões com detalhes e entusiasmo, chegando a se emocionar em certos momentos, principalmente ao relatar a história de sua vida.

Vinda de uma família de classe média baixa, é filha do meio entre seis irmãos, quatro deles homens e duas mulheres. Sua mãe, dona de casa, criou os(as) filhos(as) praticamente sozinha, visto que seu pai era caminhoneiro e passava grande parte do tempo viajando. Quanto à infância, Gislaine considera ter sido um ótimo período de sua vida, pois morava perto de seus parentes e, por isso, podia brincar com seus(as) primos(as) na rua. Também afirma ter uma maneira de pensar muito rápida, o que atribui às brincadeiras e aos jogos cultivados na infância, a exemplo do War $^{17}$ e do xadrez.

Sua adolescência é narrada em lembranças bastante animadas, sempre na companhia de primos(as) e amigos(as) com quem frequentava festas e bailes. Todavia,

\footnotetext{
${ }^{16}$ Entrevista realizada em 13 de junho de 2014.

17 Jogo de tabuleiro em que o mapa está dividido em seis regiões (Europa, Ásia, África, América do Norte, América do Sul e Oceania). Os(as) participantes devem cumprir seus objetivos, atacando seus oponentes com seu exército.
} 
devido ao ciúme de seu pai e de seus quatro irmãos, contava com um controle excessivo por parte da ala masculina da família, sobretudo porque até seus 18 anos, quando nasceu sua irmã, ela permaneceu como única filha mulher. Embora sua mãe fosse mais maleável, tal controle lhe causava revolta e a levava, muitas vezes, a brigar, xingar e chorar.

Casada há 31 anos na ocasião da entrevista, Gislaine conta que o período entre conhecer seu futuro marido e com ele se casar foi curto. Durante certas férias de dezembro e janeiro, em visita a uma tia em Passos (MG), ela foi a um clube nadar e lá conheceu um rapaz que morava em Ribeirão Preto (SP) e que também estava a passeio na cidade mineira. Namoraram por correspondência e telefone durante oito meses, até que seus pais mudaram-se para Cuiabá (MT). Por medo de perdê-la, ele a pediu em casamento. Aos 21 anos, então, Gislaine se casou e, junto ao marido e à família, iniciou uma nova vida no Estado do Mato Grosso.

Suas atividades estudantis e docentes foram, muitas vezes, interrompidas pelo ciúme do marido e pelo dilema em torno de ser, ao mesmo tempo, esposa, mãe e trabalhadora. Depois de ter cursado o magistério, interrompeu a graduação em Pedagogia em três ocasiões, tendo concluído o curso em SJRP. Tais pausas foram motivadas pelo nascimento dos(as) filhos(as) (uma menina e dois meninos, hoje já adultos) e pelas alegações do marido, que frequentemente lhe dizia: "você abandona a casa, você abandona os filhos, você abandona tudo". Para não prejudicar seu casamento, ela cedia às vontades do esposo e trancava o curso. Em suas palavras: " $\mathrm{eu}$ sempre fui boa aluna, sempre gostei de estudar, sempre gostei de ler muito. Eu sempre interrompia porque eu ficava entre ser mãe, esposa, estudar, trabalhar. Eu tinha, eu tenho um marido muito ciumento, que me atrapalhava muito, mas sempre fui boa aluna" (Entrevista, 13 jun. 2014).

Gislaine só conseguiu terminar a graduação quando passou no concurso da Prefeitura de SJRP e precisava do diploma para se efetivar como professora. Quando seus(as) filhos(as) já estavam maiores, ela relata ter dado um ultimato ao marido: “ $O u$ termino o curso de Pedagogia ou a minha carreira vai morrer, e eu não vou deixar a minha carreira morrer" (Entrevista, 13 jun. 2014). Foi assim que ela finalmente se habilitou como pedagoga. 
A privação da liberdade feminina é uma marca constante no relato de Gislaine, fazendo-se notar tanto em relação ao controle paterno, quanto nas dificuldades que ela enfrentou devido ao ciúme do marido e à necessidade de conciliar os papéis de mãe, esposa e profissional da educação.

Em seu relato, é possível observar que a condição de mãe e esposa determina o comportamento dessa professora, visto que ela sucumbe às vontades do marido e suspende sua vida profissional a fim de não desfazer o casamento. É evidente que tal atitude de aparente obediência oculta uma forma sutil e, por vezes, hostil de poder sobre a mulher, processada na conjugalidade.

$\mathrm{Na}$ tentativa de fazer uma antropologia ${ }^{18}$ da mulher, Marcela Lagarde y de los Ríos (2005, p. 367) afirma que a mulher se transforma em um sujeito dependente do homem, uma vez que "no existe como ser autónomo, sino sólo mediante los otros". Por essa razão, a identidade de mãe e esposa pode se constituir em um dos vários cativeiros $^{19}$ que privam as mulheres de autonomia, independência e possibilidade de decisão sobre suas vidas. A esse respeito, esclarece a autora:

Las mujeres están sujetas al cautiverio de su condición genérica y de su particular situación, caracterizadas por formas particulares de opresión genérica. El cautiverio de las mujeres se expressa en la falta de liberdad, concebida esta última como el protagonismo de los sujetos sociales en la historia, y de los particulares en la sociedade y en la cultura. En tanto cautiva, la mujer se encuentra privada de liberdad (RÍOS, 2005, p. 37).

\footnotetext{
${ }^{18}$ Para Marcela Lagarde y de los Ríos (2005), construir uma antropologia da mulher é concebê-la como um sujeito que produz história e conhecimento, e não apenas como um objeto a ser estudado. Nesse sentido, explica a autora: "Con la antropología de la mujer se busca evidenciar cuán históricos son el destino y las posibilidades que las mujeres tienen de apropriarse de la historia con la crítica y la desestructuración de la ideologia de la naturaliza que han interiorizado" (RÍOS, 2005, p. 64).

${ }^{19}$ Segundo Marcela Lagarde y de los Ríos (2005), o cativeiro refere-se à condição política e cultural das mulheres na sociedade patriarcal. A partir dessa definição, a autora explora, em seu livro, cinco cativeiros que privam a liberdade feminina, sendo estes referentes à mãe-esposa, à monja, à puta, à presa e à louca. Destaco ainda que o uso desse conceito, embora possa ser associado à redução da condição das mulheres à clausura patriarcal, este trabalho não tem a intensão de encerrar as mulheres-professoras à condição de cativas. Compreendo que este conceito permite apreender também a tensão entre clausura e resistência, visto que, em alguns momentos, elas se conformam, mas em vários outros elas resistem às relações de poder que as rodeiam na sociedade patriarcal.
} 
Apesar de viver em uma espécie de cativeiro - visto que, em um primeiro momento, sofreu com o ciúme controlador do pai e, mais tarde, com o do marido -, Gislaine afirma, com entusiasmo, que gosta de ser mulher. Quando a questionei sobre as diferentes formas de ser mulher para ela, a entrevistada prontamente se referiu à vaidade, qualidade, aliás, perceptível nela própria, visto que, no momento em que a encontrei, estava vestida de maneira elegante, maquiada e com os cabelos escovados. Ai, eu sou uma mulher muito mulher, sou extremamente vaidosa. Eu
gosto, eu gosto de... eu gosto de ser mulher [...]. Eu acho que ser
mulher é representar o belo. Então, eu acho que você tem que estar
sempre apresentável, porque, quando a pessoa olhar para você e
gostar de olhar para você... Embora, assim, o homem também pode ser
isso [...]. Mas eu gosto de ser mulher, assim, por isso, por poder ser
vaidosa, por poder chorar. Na hora em que eu quiser chorar, eu
choro. Na hora de rir, eu estou rindo; de ser delicada com as pessoas,
de não precisar ser grossa. Porque o homem parece que precisa ser
grosso para mostrar que é homem. Eu não gosto disso. (Entrevista, 13
jun. 2014).

A beleza está associada à vaidade, mas também a uma noção mais tradicional de feminilidade, o que nos leva a entender que pode ser definida como o cuidado com o corpo e com a aparência. O relato de Gislaine indica a presença e a falta da vaidade como um elemento de distinção entre as diferentes formas de ser mulher e ser homem, já que a atribuição da vaidade às mulheres é tida como uma prática comum, ao passo que, no caso dos homens, o cuidado com o corpo e com a aparência se dá por meio de uma aproximação tímida.

Segundo Naomi Wolf (1992), a partir dos anos de 1970, as mulheres quebraram barreiras sociais significativas e passaram a ocupar espaços até então destinados aos homens. No entanto, à medida que as mulheres obtiveram tais conquistas, muitas delas, em virtude da teoria e da ação política da segunda onda dos feminismos, também se tornaram prisioneiras do cuidado com o corpo. Em outras palavras, houve um crescimento em relação à busca pela aparência ideal e pelo corpo perfeito, fenômeno que Wolf denomina mito da beleza. De acordo com a pesquisadora, essa ideologia da beleza "se fortaleceu para assumir a função da coerção social que os mitos da maternidade, domesticidade, castidade e passividade não conseguem mais realizar" (WOLF, 1992, p. 12). 
Wolf (1992) esclarece que o mito da beleza data do fim do século XIX, sendo contemporâneo ao início da industrialização e da urbanização, bem como, sobretudo, à expansão da classe média, o que, por sua vez, deu origem a uma classe de mulheres alfabetizadas e ociosas. De acordo com a autora, ao reconhecer nessas mulheres um potencial de consumo, o capitalismo industrial lançou um modelo de beleza destinado às senhoras da classe média. Assim sendo:

$\mathrm{Na}$ década de 1840, foram tiradas as primeiras fotografias de prostitutas nuas. Anúncios com imagens de "belas" mulheres apareceram pela primeira vez em meados do século. Reproduções de obras de arte clássicas, cartões-postais com beldades de sociedade amantes dos reais, gravuras de Currier e Ives e bibelôs de porcelana invadiram a esfera isolada à qual estavam confinadas as mulheres de classe média (WOLF, 1992, p. 18).

É justamente nesse contexto que, na segunda metade do século XX, parte das mulheres da classe média conseguiu se desvencilhar de alguns padrões sociais impostos ao feminino, como a domesticidade e a maternidade. Entretanto, o mito da beleza permaneceu como uma ficção social naturalmente atribuída a um tipo de feminino, ou seja, a mulher branca e, como já foi dito acima, a de classe média. Destaco esse contraponto, pois quando pensamos na categoria mulher, encontramo-nos diante de uma multiplicidade de sentidos e desigualdades que devem ser levadas em conta, visto que o grupo de mulheres que constituem os sujeitos dessa pesquisa não são negras, não são transexuais, não possuem nenhuma deficiência física ou mental e, muito menos, se encontram em condições de miséria, características múltiplas que nos levam a pensar se a beleza seria um quesito definidor do que se entende por mulher.

Isso posto, nota-se, especificamente, em Gislaine um discurso que enfatiza que ser mulher é sinônimo de ser e construir-se bela. Assim, ao definir a beleza como peculiaridade da mulher, a fala dessa professora reforça que características como delicadeza, emotividade e vaidade são elementos naturalmente femininos. É nesse sentido que o gênero, como categoria de análise histórica, opera e fornece subsídios para a construção social de homens e mulheres.

Ainda em relação às diferentes formas de ser mulher, é interessante mencionar que a associação da beleza à feminilidade condiciona Gislaine à resistência em relação ao que ela entende por movimento feminista. Tal reação se explicita quando a 
professora ressalta que, por ela considerar a vaidade e a fragilidade como componentes definidores de uma forma específica de ser mulher, uma feminista (segundo sua concepção) não gostaria e não aceitaria o seu modo de ser mulher:

Eu não conheço nenhuma feminista, porque ela ia acabar comigo. Não tenho tendência feminista, não tenho preocupação de que, se o homem ganha mais do que eu... Não me importa isso, eu ganho pelo meu trabalho. Assim, e se não está bom, eu conquisto mais. Você entendeu? Não fico lutando, disputando nada com homem. Não tenho essa preocupação, não sou feminista mesmo, não sou. O texto... Eu me lembro que um texto falava sobre isso, mas eu não me lembro direito o que que era. Eu acho que as feministas não iam gostar muito de mim, não [...]. Você não viu que eu, embora eu seja uma mulher que lê, uma mulher instruída, uma mulher que estudou, uma mulher que gosta de educação, eu abri mão de terminar a faculdade várias vezes para não brigar com o marido, mas não por ele me dominar. Sabe aquela questão de evitar conflito? Eu não queria ficar arranjando confusão. Pra que ficar arranjando problema? (Entrevista, 13 jun. 2014).

Para a entrevistada, "essa igualdade muito grande" entre homens e mulheres, além de ofuscar a fragilidade feminina, pode também ocasionar conflitos:

Ah, porque feminista, para mim, eu enxergo ela assim: que ela acha que mulher não é... não tem que ser sexo frágil, no caso, né? Embora eu não me julgue sexo frágil, não, mas que fica essa disputa [...]. Porque o homem, no mesmo trabalho, ganha o mesmo tanto... e eu não fico me preocupando em mudar isso. Eu não. Elas lutam por isso. Acha bobagem usar rosa, né? Por exemplo, eu acho que a feminista não faz o quarto da menina todo cor de rosa, não. Eu imagino isso. Eu não sei muito sobre elas. Eu que acho que elas não vão gostar muito de mim, não, porque eu fiz o quarto da minha filha todo cor de rosa, na época. Também, 28 anos atrás. Que mais que eu sei das feministas? [...] Essa igualdade muito grande que elas querem entre homens $e$ mulheres, eu não sou muito dessa não. Por exemplo, eu jamais vou pegar um serrote, igual o meu marido fez ontem, e serrar os galhos da árvore que estavam caindo em cima do nosso carro e arranhando o carro; eu jamais vou subir no telhado lá em cima para desentupir calha. Quer dizer, coisa que exige força, eu não vou fazer mesmo. Então, feminista acha que não, tudo que o homem faz, a mulher faz (Entrevista, 13 jun. 2014).

Diante do discurso de Gislaine sobre feminismos e feministas, vem-me à lembrança o peso daquilo que Margarita Pisano (2004) define como a reprodução de um modelo de ser feminina: a feminilidade patriarcal. Ao fazer referência à delicadeza (quando menciona o quarto rosa da filha), à fragilidade (quando se nega ao uso da força 
física) e à harmonia (quando renuncia à carreira para não brigar com o marido ou quando diz não se importar em competir em termos salarias com os homens), a professora mostra o quanto é difícil e complexo uma mulher se desvencilhar do feminino patriarcal.

A reprodução e a identificação com a feminilidade patriarcal se dá pelo fato de estarmos imersas em uma cultura masculina que "estructuró, atrapó y legitimó para sí o valor fundamental que nos constituye como humanos y humanas: la capacidade de pensar" (PISANO, 2004, p. 3). Nessa perspectiva, Pisano (2004, p. 5) afirma que não podemos pensar que masculinidade e feminilidade são instâncias distintas, dado que a feminilidade nada mais seria do que uma dimensão da masculinidade: "La feminilidad no es un espacio autónomo con possibilidades de igualdad, de autogestión o de independencia, es una construcción simbólica u valórica diseñada por la masculinidade y contenida en ella como parte integrante”. Em outras palavras, nós, mulheres, muitas vezes reproduzimos a cultura patriarcal quando nos submetemos ao domínio masculino e procuramos cumprir o modelo de sermos acolhedoras e cordatas, assumindo a perspectiva de que sempre necessitamos do outro para sobreviver.

Entretanto, mesmo sem se dar conta, Gislaine utiliza-se das ideias feministas ao argumentar que os serviços domésticos não devem ser prioritários às mulheres, visto que, se o marido e os(as) filhos(as) vivem na mesma casa, é dever de todos mantê-la organizada:

[...] ele me ajuda a lavar a louça, ele me ajuda a botar uma roupa, não porque eu sou feminista. É divisão, é o seguinte: nós somos uma família. Eu acredito que ali todo mundo come, todo mundo faz, e nada mais justo do que todo mundo ajudar, entendeu? Então, todo mundo ajuda, todo mundo descansa junto, cada um faz a sua parte. O meu marido chega, se ele tiver que fazer o almoço, ele faz. É tranquilo, mas não porque eu fico assim: "Ah, por que que eu vou fazer a comida? Porque eu sou a mulher?". Não. Quem chegar primeiro e tiver a oportunidade de fazer, faz. Se sou eu que estou tendo tempo, eu faço; se é ele que tem, ele ajuda; se é o filho, a nora que está lá, faça, né? Não: "Por que que eu que tenho que varrer a casa? Porque eu sou mulher?". Não, mas quando tem que usar a força física, ah, bem, aí é o homem mesmo, porque eu não vou fazer força física (Entrevista, 13 jun. 2014). 
A recusa de Gislaine ao que ela supõe ser feminista assenta-se não só na reprodução da feminilidade patriarcal (PISANO, 2004), mas também em um desconhecimento sobre o movimento e as teorias feministas. Os relatos da entrevistada atestam que, embora ela faça parte da luta diária das mulheres em busca de reconhecimento profissional e de maior equidade entre gêneros, ela não se reconhece no interior do movimento social de mulheres, uma vez que seu discurso, mesmo que não declaradamente, ratifica a misoginia, pressuposto básico para o domínio da cultura patriarcal.

Já sobre o significado de ser professora, o depoimento de Gislaine carrega certa propensão ao natural semelhante às características que direciona ao seu modo de compreender o que é ser mulher, visto que ela entende seu trabalho como estando vinculado a um dom que lhe é próprio. Ao explicar-me sua escolha pelo magistério, por exemplo, Gislaine refere-se ao que acredita ser sua habilidade na docência:

Eu escolhi sozinha. Sozinha. Desde pequenininha eu sou a primeira mulher da família [...] a se formar numa profissão, ter uma profissão, e depois fazer curso superior. Fui a primeira [...]. E eu fiz isso... Eu estava terminando, a minha mãe perguntou onde eu ia estudar. Eu falei que eu queria fazer a Escola Norma, e a minha mãe foi lá e fez a matrícula, e eu fiz [...]. E eu sempre me destaquei nas aulas de Didática. Eu acredito que eu nasci com o dom para ser professora (Entrevista, 13 jun. 2014).

Além de se referir ao dom, Gislaine afirma, ao expor-me o que é ser professora para ela, que o(a) educador(a) é um(a) exemplo, um(a) modelador de atividades e pensamentos. Em sua perspectiva, é o(a) professor(a) que incita na criança o desejo por aprender. Desse modo, conforme complementa a entrevistada, um dos quesitos principais para estimular a aprendizagem do(a) aluno(a) seria o gostar de crianças e o uso da criatividade para a elaboração da aula.

A partir desse argumento, a ideia de dom aparece novamente em seu discurso, quando ela apresenta uma distinção entre a "professora nata", aquela que nasceu para ser professora, e a "dadora de aula", aquela que simplesmente executa sua profissão:

Eu acho que é gostar. A primeira coisa é gostar de criança. Gostar das crianças e gostar que elas aprendam, porque muita gente estuda e vem entrar numa sala de aula... Eu falo assim: "Tem professoras e 
dadoras de aula". "Dadoras de aula". Eu acho assim: querer que qualquer criança aprenda. Eu tenho horror de professora que seleciona aluno, que fala: "esse não aprende mesmo" [...]. É, infelizmente, a gente não muda todo mundo, e esse tipo de professor eu acho que não nasceu para isso, porque tem muita gente que escolheu magistério, Pedagogia, por ser mais fácil, para correr da matemática, para correr da ciência exata. Eu tenho visto aí umas que, infelizmente, fica só torcendo para chegar a época de aposentar, e entra pelo salário, porque não tem outra oportunidade. Mas não acredita nas crianças (Entrevista, 13 jun. 2014).

É interessante mencionar como, ao utilizar a palavra dom, Gislaine acaba por naturalizar a carreira docente. Isso ocorre porque, conforme expõe Claudia Vianna (1998, p. 324), “palavras como 'sempre', 'desde criança', 'desde pequena' indicam em muitas das falas que a docência deveria ser algo com o qual se 'nasce', quase um 'dom', uma "vocação"”.

A caracterização do trabalho docente como um dom, marcado pelo gosto por crianças e pela dedicação, evidencia também como as relações de gênero perpassam as diferentes formas de ser professora, uma vez que as características mencionadas por Gislaine em relação à identidade profissional são frequentemente atribuídas também ao seu modo de compreender o que é ser mulher. É justamente nesse contexto que a docência se torna uma carreira socialmente feminina:

Nossa socialização interfere na forma como nós - homens e mulheres nos relacionamos, nas profissões que escolhemos e na maneira como atuamos. Não para dizer que sempre foi assim, ou que é próprio da nossa 'natureza', mas para afirmar que as expressões da masculinidade e da feminilidade são historicamente construídas (VIANNA, 2002, p. $53)$.

Assim, é a partir da definição do que é socialmente feminino e do que é socialmente masculino que atividades como alimentação, maternidade, cuidado e educação são destinadas às mulheres. Em virtude dessa atribuição de estereótipos a homens e mulheres, é possível notar, portanto, como a atividade docente torna-se marcada por significados considerados femininos pela sociedade patriarcal. Nas palavras de Vianna (2002, p. 54):

Esses significados se baseiam nas diferenças entre os sexos, mas indicam também uma construção social - a partir dessas diferenças - 
que ajuda a explicar as relações de poder que definem a divisão sexual do trabalho e a inserção das mulheres em profissões ligadas às funções consideradas femininas e socialmente mais desvalorizadas.

Em relação à participação no curso GDE, Gislaine assume que sua adesão foi estimulada por oportunidades de ascensão na carreira docente, já que fazer o curso lhe ajudaria em sua progressão funcional. Consequentemente, a professora também admite que não aplicou o projeto Gênero e sexualidade na escola infantil, elaborado por ela durante a avaliação final do curso com o objetivo de abordar sexualidade e relações de gênero a partir das curiosidades das crianças:

Olha, eu vou ser sincera. Na época, quando estava oferecendo curso a distância... Como eu disse para você, eu sempre tive dificuldade de fazer o curso presencial por causa do marido. E aqui, eu era professora nessa época, a Secretaria da Educação, a gente tem progressão funcional [...]. E eu não tinha ainda um curso de 180 horas, eu tinha a especialização de 360 horas. Sempre fiz curso de 30 horas, e foi a primeira oportunidade que eu tive para fazer um curso de 180 horas. Aí foi oferecido aqui, aqui é de fácil acesso para mim, na Secretaria, porque eu moro aqui perto. E era esse o curso que tinha, eu nem sabia bem direito do que que é que ia falar (Entrevista, 13 jun. 2014).

Contudo, ainda que a professora relate ter apresentado certo desinteresse no início do curso, as leituras do material produzido na plataforma Moodle evidenciam que ela não ficou isenta às discussões proporcionadas pelo GDE, visto que demonstrou resistências, propôs questionamentos e até reflexões acerca de seu modo de ser professora.

Este assunto sexualidade não é fácil de se tratar, escrever, falar, julgar, sem preconceitos ou discriminações, temos muito ainda que estudar e nos aprimorarmos (Diário, 12 set. 2009).

[...] será que como educadora não estou reproduzindo esta cultura machista da nossa sociedade? Pois ainda muitas mulheres são agredidas diariamente em nosso país, a Lei Maria da Penha está aí para comprovar isto, mas será que esta lei faz com que homens que agridem mulheres reflitam sobre sua crueldade ou apenas os reprimem, por medo da prisão? (Diário, 20 set. 2009).

o $3^{\circ}$ módulo (Sexualidade e Orientação Sexual) foi o que mais mexeu com meus valores, preconceitos e me fez refletir quanta ignorância de minha parte sobre a diversidade sexual, e identidade de gênero. Vi o quanto era uma educadora reprodutora de tantas discriminações e 
diferenças e preconceitos ditos como ética moral, desta falsa sociedade (Memorial, 12 nov. 2009).

O envolvimento de Gislaine com o GDE também se explicitou durante a entrevista, já que, segundo seu relato, o curso lhe proporcionou uma reflexão sobre sua atuação como professora e até mesmo como mulher. Tal prerrogativa fica evidente quando ela alega ter notado a distinção de gênero no uso de cores binárias como azul e rosa em sala de aula, compreendendo que suas práticas e atitudes como professora estão ligadas à forma como foi socializada como mulher:

[...] depois que eu comecei fazer, eu gostei, eu me envolvi. Eu vi o quanto ele era importante, como professora, para a gente. Porque a gente, às vezes, tem essa mania também de fazer capa cor-de-rosa para as meninas, capa azul para os meninos. A gente tinha essa mania, né?, que é uma coisa da criação da gente e que hoje me fez abrir os olhos, também porque a gente não pode ficar fazendo essa influência, né?, influenciando isso. Então, depois que eu comecei a fazer o curso foi que eu me envolvi com ele, que eu entendi, que eu gostei, que eu comecei a estudar o material. Que a gente tinha que ler todo o material, né? Então, aí eu me envolvi [...]. A gente só enxerga as crianças hétero, né? E a gente tem crianças que mostram um diferencial. No começo da minha carreira, a gente tinha a tendência sempre de falar: "Isso é coisa de menina. Isso é coisa de menino". Você não faz isso. O tipo de coisa... A gente mandava a menina: "Senta direito"; "Fecha as pernas". Nós tínhamos esse comportamento, porque nós herdamos isso, a nossa criação foi assim. E esse curso me fez pensar melhor sobre isso, que a gente deve tomar cuidado, porque senão a gente massacra as crianças. Nesse sentido, tira deles a oportunidade de ser quem eles são, né? Então, nesse ponto, eu também comecei a observar isso [...]. Eu acho que foi mais uma aceitação de enxergar [...]. Eu acho que foi uma aceitação, uma mudança de visão (Entrevista, 13 jun. 2014).

As reflexões que a entrevistada passa a ter em sala de aula também parecem ser transferidas para sua vida pessoal, já que ela fala sobre aceitação quando se refere ao âmbito familiar. Nesse sentido, ela consegue entender sua mudança de opinião e, consequentemente, de reconhecimento da orientação sexual de sua prima:

Houve mais aceitação minha, porque eu sou de uma criação... Igual, eu também disse para você que fui criada: homens, mulheres, mas definidos. Não cresci, não vi caso nenhum na minha família, assim, que aparenta. Embora, agora, depois de adulta, que eu voltei em Belo Horizonte, porque tinha muitos anos que eu não via uma prima, que ela mesmo virou para mim, que assumiu que ela gosta de mulher, e ela 
falou isso numa reunião familiar, assim. E eu, na hora, eu falei: "Nossa, eu não imaginava". Só que aceitação melhor; porque, antes, quando eu comecei a minha carreira profissional, a gente tentava podar isso (Entrevista, 13 jun. 2014).

É possível afirmar que as concepções de Gislaine sobre o que entende por ser mulher e por ser professora, apesar de serem carregadas de explicações que tendem à naturalização de pensamentos, práticas e atitudes referentes ao feminino, trazem resistências quanto às imposições do patriarcado. Isso se torna perceptível, por exemplo: quando ela relata que, em sua infância, brincava de War e xadrez, jogos regidos por estratégias e geralmente mais destinados aos meninos do que às meninas; quando narra toda sua luta para driblar o ciúme do marido e, assim, finalizar a graduação; ou mesmo quando refuta as ideias feministas, mas acaba se utilizando delas para justificar como funciona a divisão das tarefas domiciliares em sua casa.

Por fim, se sua participação no GDE foi marcada por um desinteresse inicial, conforme já dito, o decorrer do curso ocasionou seu envolvimento nos fóruns de discussão e nas atividades propostas. É nesse sentido que seu entendimento sobre o que é ser mulher e ser professora sofre certo deslocamento, nela provocando questionamentos e reflexões a respeito da condição feminina em sociedade e da diversidade sexual e de gênero presente na escola.

\subsection{Celina: "Hoje, eu não seria professora" 20}

Natural de São José do Rio Preto, Celina sempre morou na cidade do interior paulista. Durante boa parte de sua infância, lembrada como um período pobre, sua família residiu na casa dos avós maternos, o que contribuiu para a criação de um forte laço afetivo entre ela e a avó. Não por acaso, ela continuou a viver na casa até que completasse 19 anos, mesmo após seus pais terem conseguido mudar-se para uma casa própria.

\footnotetext{
${ }^{20}$ Entrevista realizada em 13 de junho de 2014.
} 
Aos 47 anos quando concedeu a entrevista, Celina tem um irmão (13 anos mais novo), e uma irmã (um ano mais nova). Devido à proximidade de idade entre ela e sua irmã, as duas sempre foram companheiras e costumavam sair juntas durante a adolescência, por ela relatada como uma fase tranquila e repleta de amigos(as). Assim como Gislaine, conta que teve de enfrentar o ciúme do pai diante das saídas com os(as) amigos(as) e do início de um namoro. Em contrapartida, sublinha as diferenças existentes na relação do pai com o irmão, marcada por muita liberdade.

Sua concepção sobre o que é ser mulher também é permeada pela vaidade:

[...] eu acho que você tem que ser vaidosa, tem que saber se comportar. Eu acho que mulher é tudo isso, sabe? Ser algo que seja bem, assim, à frente, bem realizada, bem decidida, não ter, assim, autoestima baixa (Entrevista, 13 jun. 2014).

[...] se dar ao respeito, porque, hoje, eu acho que a mulher está muito desvalorizada. Que nem a minha irmã esta semana estava comentando, porque ela viaja muito, e ela estava nos Estados Unidos, e aí eles falavam assim: "Ah, você é brasileira?"; "Sim."; "Bunda, né? Bunda, né?". Quer dizer, ela falou: "Bunda é no Rio de Janeiro. Onde eu moro é muito respeito". Então, [...] a mulher aqui, no Brasil, tem bunda, entendeu? Não tem cérebro, não tem nada. Ela ficou, assim, super sem graça, mas ela falou que ela respondeu à altura. Mas, quer dizer, nós, mulheres, tínhamos que nos dar mais o respeito. Por quê? Porque o homem está muito fácil, porque, hoje, você pode reparar que você não encontra uma pessoa adequada para você; e aquelas que têm, as outras dá em cima, sai com o marido da outra. E, tipo, mulheres desse jeito que o mundo está assim, porque, se cada um se respeitasse, teria para todo mundo, né? (Entrevista, 13 jun. 2014).

Nesse sentido, por mais que refute a atitude ciumenta do pai direcionada a ela e à irmã e perceba a diferença de concessão de liberdade em relação ao irmão, Celina acaba reproduzindo a visão e o discurso machista sobre as mulheres, tal como acontece com Gislaine. Isso fica evidente em sua fala ao caracterizar a mulher como um sujeito recatado.

O próprio modo de se portar de Celina é reservado e tímido, tendo em vista os relatos sobre sua história de vida e as horas em que estive com ela durante a entrevista, ocorrida em sua casa. Vestida de maneira discreta e dona de uma voz baixa, a professora apenas pareceu mais à vontade em nossa conversa quando o marido, que até então estava trabalhando em casa, saiu. 
A internalização do discurso machista pelas mulheres é resultado, conforme explica Margarita Pisano (2004, p. 4), do fato de a masculinidade funcionar como uma supra-ideologia que "he cruzado siempre los sistemas culturales, ha impuesto las políticas, las creencias, ha demarcado las estructuras sociales, raciales y sexuales". Nessa lógica, o que estrutura a capacidade de pensar, inclusive das mulheres, é a masculinidade, pressuposto que nos faz compreender, em certa medida, a fala de Celina. Como já dito, a masculinidade é parte estruturante da feminilidade, pois é ela que configura a construção simbólica do feminino.

Quanto ao entendimento de Celina sobre o que é ser mulher, ele se centra também em outros quesitos além da vaidade: na realização profissional e em uma visão mais despojada sobre a maternidade. Casada há 13 anos, a entrevistada não tem filhos(as). Conheceu seu marido no período em que ministrou aulas no Serviço Nacional de Aprendizagem Industrial (SENAI), quando ele foi seu aluno. Segundo ela, o casal possui um bom relacionamento matrimonial.

Com relação à maternidade, ela afirma nunca ter tido vontade de ser mãe, uma vez que sempre cuidou dos(as) sobrinhos(as) e que se considera psica, ou seja, uma pessoa ansiosa, metódica e que possui certas obsessões e tiques, o que, segundo ela, faria a criança sofrer. O marido, por viajar muito e ter um filho de um casamento anterior, não se importou com sua opção por não ter filhos(as).

Tal decisão, de certa forma, pode nos levar a pensar que Celina negou um dos cativeiros destinados à mulher, segundo a compreensão de Marcela Lagarde y de los Ríos (2005): a maternidade. No entanto, ao assumir o cuidado dos(as) sobrinhos(as), ela incorpora as prescrições tradicionalmente atribuídas às mulheres sobre a necessária atividade de maternar seus próprios filhos.

Isso se dá pois, como afirma Ríos (2005), a conformação do feminino ao papel de mãe e também de esposa inicia-se mesmo antes do nascimento da menina e se estende durante a vida da mulher, em um longo processo de socialização. Por conseguinte, a aprendizagem sobre como ser mãe e ser esposa culmina na conjugalidade e na maternidade, instâncias sociais que: "organizan e conforman los modos de vida femininos, independientemente de la edad, de la clase social, de la definición nacional, religiosa o política de las mujeres (RÍOS, 2005, p. 363). 
Por outro lado, ainda como argumenta Ríos (2005), a organização e a conformação da vida das mulheres à conjugalidade e à maternidade se dão de forma tão complexa que não necessariamente a mulher precisa estar casada ou ter filhos para se tornar mãe ou esposa. Em outras palavras, basta que a mulher exerça a função de cuidar - seja do pai, do irmão, de familiares em geral, do namorado, do vizinho, do chefe e dos amigos - para que ela desempenhe atividades maternais e matrimoniais. É possível dizer, portanto, que o cuidado e a experiência de doação incondicional, características que marcam a maternidade, foram vivenciados por Celina, embora ela não tenha gerado e parido filhos(as).

Sobre se considerar psica, a entrevistada relata ter sido assim desde criança. Ela revela, mais especificamente, sua obsessão por limpeza, a ponto de não andar descalça e não pisar em areia.

A minha mãe que comentava. Ela comentava que eu era muito fresca, que eu nunca pus a mão no chão, e até hoje eu sou. Por exemplo, eu não posso ir em qualquer banheiro, eu não posso beber em qualquer copo, porque eu pego infecção muito rápido, então tem tudo isso aí (Entrevista, 13 jun. 2014).

Celina afirma já ter se acostumado com seu jeito de ser e declara que hoje o considera normal. No entanto, seu comportamento metódico e, ao mesmo tempo, tímido pode ser percebido na maneira como ela lida com sua própria sexualidade. Em outras palavras, ela admite sentir vergonha ao falar sobre sexo, assunto que lhe suscita um bloqueio:

Eu sou muito tímida de falar sobre sexo, essas coisas. Eu tenho bastante vergonha, isso eu sempre tive. Às vezes as meninas falavam na escola, eu fico vermelha. Tanto é que, quando você me perguntou, você pode reparar que eu fiquei hiper vermelha, né? E ainda o meu marido estava aí, piorou a situação. Eu não conseguia nem te responder, mas eu sempre fui assim, bloqueada pelos meus pais, porque na minha casa nunca tinha esse tipo de assunto. O meu pai e a minha mãe se trancavam no quarto, o assunto era deles lá. E eles aproveitavam, sempre faziam quando eu e a minha irmã não estávamos em casa, então nunca teve esse tipo de contato liberal, que nem hoje tem [...]. Às vezes, eu vou viajar com as minhas amigas... Nós fomos para a praia e os assuntos saíram. Ah, sabe esses assuntos que a gente sempre fala? Eu já fiquei sem graça, eu já perdi o rebolado, eu não consigo falar normalmente, entendeu? (Entrevista, 13 jun. 2014). 
O bloqueio de Celina ao falar de sexualidade tornou-se evidente durante o curso GDE. Em seu memorial, por exemplo, a professora relatou tal dificuldade: "sabia que os temas seriam angustiantes, que não concordaria com muitas coisas, mas as minhas expectativas eram maiores" (Memorial, 21 abr. 2010).

O embaraço em relação ao sexo pode ser explicado pela forma como ela foi socializada como sujeito sexual. Tal prerrogativa se comprova pelo excerto de seu relato há pouco apresentado, no qual Celina evidencia uma concepção de sexo como algo privado e íntimo, ao narrar que seus pais nunca conversaram sobre sexualidade em casa.

A valorização da sexualidade como segredo é discutida por Foucault (1985) em sua negação da ideia de uma hipótese repressiva. Segundo o autor, as sociedades modernas, ao mesmo tempo em que consideram a sexualidade como algo privado, teriam testemunhado uma explosão discursiva, e não uma repressão relativamente ao sexo, tanto que os desejos e prazeres sexuais acabam por se tornarem objeto de ciências como a demografia, a biologia, a medicina, a psiquiatria e a psicologia, entre outras. Em suas palavras, o que "é próprio das sociedades modernas não é terem condenado o sexo a permanecer na obscuridade, mas sim o terem devotado a falar dele sempre, valorizando-o como segredo" (FOUCAULT, 1985, p. 36).

Nesse sentido, a proliferação de discursos sobre a sexualidade possibilitou, de acordo com Foucault (1985), um conhecimento minucioso sobre o sexo, o que, por sua vez, engendrou uma classificação das sexualidades e uma multiplicação dos prazeres. Isso posto, a partir do século XIX temos uma agência específica para os assuntos sexuais, a Sciencia Sexuales, instituição que, apoiada em procedimentos de interdição, prolifera numerosos discursos sobre o sexo, os quais funcionam como verdades. Averigua-se assim, portanto, a existência de uma lógica: a de que o saber é uma forma de poder e controle.

[...] ao invés de partir de uma repressão geralmente aceita e de uma ignorância avaliada de acordo com o que supomos saber, é necessário considerar esses mecanismos positivos, produtores de saber multiplicadores de discursos, indutores de prazer e geradores de poder (FOUCAULT, 1985, p. 71). 
A partir do que discute Foucault (1985), pode-se dizer que a fala de Celina evidencia a historicidade do fenômeno que trata o sexo como algo privado e reservado em nossa sociedade. No entanto, mesmo se tratando de uma dimensão particular e íntima, a sexualidade precisa ser explorada e debatida na escola, tal como a própria entrevistada defende no fórum do módulo 3 (Sexualidade e Orientação Sexual):

Sou a favor a implantação de aulas sobre sexualidades nas escolas com especialistas na área. $O$ estudo das práticas e significações atribuídas pelos professores ao gênero e à sexualidade possibilita refletir como as relações pessoais cotidianas, o que é aparentemente rotineiro, não causa indignação. Em consequência disso, valores e preconceitos sustentam os mecanismos de produção das várias formas de exclusão e desigualdades sociais na instituição escolar (Fórum, 7 mar. 2010).

É justamente nesse contexto que começo a discorrer sobre Celina como professora. Conforme relatou, ela fez a graduação em Pedagogia em uma faculdade particular, posteriormente tendo cursado pós-graduações (lato sensu) em Didática do Ensino Superior, Didática do Ensino Fundamental e Infantil, e Psicopedagogia. Concursada pela Prefeitura de SJRP há 27 anos, ministra aulas para o $3^{\circ}$ ano do Ensino Fundamental. Não se aposentou ainda por não ter idade suficiente, mas já pensa em abrir um negócio - uma cafeteria, por exemplo - após a aposentadoria.

Durante nossa conversa, Celina afirmou que o magistério não foi sua primeira escolha profissional. Devido a questões financeiras, porém, não teve condições de estudar Direito, percurso que teria escolhido. Assim, uma vez cursado o magistério, acabou encaminhando-se à Pedagogia e, como na época encontrou boas possibilidades de trabalho na área, optou por permanecer na carreira docente.

Mesmo estando estável na profissão há anos, suas expectativas quanto ao magistério são pessimistas, o que confirma seu desgaste e seu desencanto pela educação. Tal posicionamento torna-se nítido quando a questiono sobre o que entende por ser professora:

O que é ser professora? Uma responsabilidade muito grande, sabe? Você tem que assumir um monte de tarefa que não é sua, sabe? E, além de tudo, você traz para casa, você pensa no aluno que não aprende, no porquê não aprende, a mãe não tem responsabilidade, não te leva, não leva num, sabe?, num especialista para ver o que que essa 
criança tem. Muitas vezes, eu acordo, eu falo: "Ai, gente, o quê que eu vou fazer com fulaninho? O que quê?". Sabe, é muita responsabilidade que, no fundo, não é sua, que é da mãe, que é da criança que não aprende, deve ter um déficit, deve ter algum problema e a mãe não percebe. E aí o ano passa, acabou a sua vez, vai para o próximo, a criança não avança [...]. É uma responsabilidade muito grande. Hoje, eu não seria professora (Entrevista, 13 jun. 2014).

Tal excerto demonstra toda a insatisfação de Celina com a docência. Isso se dá pois, além de não ser valorizada e reconhecida profissionalmente, ela ainda se sente responsável pelos entraves que não deixam fluir a aprendizagem das crianças. O trecho seguinte manifesta-se na mesma direção:

Então, sabe?, se sente mal, se sente incompetente. Você vai se desgastando, vai, sabe?, levando umas coisas que, no fundo, não são suas. Mas isso vai te magoando, vai te estressando, porque, aliás, eu acho que toda profissão tem, mas eu acho que a do professor é a pior, porque você fica decepcionado com pai, com pais, você fica decepcionado com o aluno que não avançou, você fica decepcionado com o governo, porque o menino precisa de tratamento hoje, daqui no final do ano que vai receber [...]. Hoje, infelizmente, eu não seria professora. E quando os meus alunos falam, eu falo: "Não, vai procurar uma profissão melhor". Porque eu acho que é muito desvalorizado, muito desgastante e muito desvalorizado. Todo mundo fala que ganha pouco, a questão não é ganhar pouco. O que você, na verdade, sente, é um sentimento muito ruim, sabe? [...] Você entendeu? Então, tem tudo isso que você analisa, tem criança que não lembra quem foi o professor, não sabe nem o nome. E os pais chegam na escola, nem conhecem o professor do filho, nem sabem o nome: "Ah, é aquela moreninha, aquela negrinha. É aquela loirinha. É aquela da segunda porta ali, uma alta de cabelo comprido". Sabe, eles não sabem o nome do professor. Então, é uma culpa muito grande que você leva (Entrevista, 13 jun. 2014).

A fim de dialogar com o relato de Celina, é válido recorrer a uma pesquisa de Cláudia Vianna (1998) que teve por objetivo investigar o que é ser e estar professor(a) para 13 docentes do Ensino Fundamental e Médio da região de São Paulo. Isso porque, no referido trabalho, a autora encontrou o desencanto e a paixão como dois aspectos relevantes entre as docentes pesquisadas. Em sua análise, o desânimo, o desgaste e o esgotamento de professoras(es) vêm atrelados às suas denúncias acerca das precariedades nas condições de trabalho, do contínuo processo de arrocho salarial e do desprestígio da ação educativa. 
Não obstante, Vianna (1998) observa uma contradição nessas falas, já que, mesmo insatisfeitos(as), tais profissionais ainda permanecem na carreira docente. Segundo ela, o gosto por dar aulas e a realização pessoal pesam no abandono da carreira docente, de modo que pensar a docência somente em uma perspectiva negativa não revela a complexidade envolvida na atividade de lecionar.

Tal complexidade é notada, no caso de Celina, no fato de que, apesar de o magistério não ser sua primeira opção profissional e de sua atuação ser atravessada pelo desencanto, ela demonstra preocupação com a aprendizagem de seus(as) alunos(as). Isso se torna perceptível quando ela menciona crianças que não aprendem e famílias que não se importam em resolver o problema, tal como já exposto; ou, então, quando demonstra preocupar-se com a responsabilidade envolvida no preparo de atividades diferenciadas para ajudar os(as) alunos(as) com dificuldades.

[...] tem pessoas que não têm responsabilidade, que vai, que leva tranquilo, sabe? E eu admiro muito. "Ah, eu não levo nem caderno para casa", eles falam. "Nem prova para corrigir, eu faço lá sala de aula". Eu não sei ficar com os meus alunos corrigindo prova, fazendo caderneta, fazendo isso e aquilo, eu não consigo fazer isso. Eu estou lá, o meu aluno está precisando: "Professora, eu não entendi". Eu estou explicando. Agora, como é que eu vou fazer uma caderneta, dando uma aula de matemática? Vou mandar ele fazer cópia? Isso não existe mais [...]. Tem dias em que eu fico sem dormir, eu perco o sono. O meu marido que o diga, porque aí eu não consigo ficar na cama, eu tenho que levantar, aí eu venho no computador procurar alguma coisa para ver o quê que eu faço, aí eu vou imprimindo um monte de atividades. Chego lá para aplicar a atividade na criança, é uma atividade perdida, porque a criança nem sabe que eu estou aplicando aquilo, eu acabei de ensinar ontem, ele não conhece [...]. É triste, é triste. Tem dia aqui, que eu chego aqui, falo para o Pedro [o marido]: "Ai, Pedro, estou arrasada". Ele fala: "Por quê?"; "Ai, aconteceu isso com o meu aluno, eu estou me sentindo incapaz". Que nem este ano, eu estou me sentindo mal, porque eu vou ter que reprovar dois alunos (Entrevista, 13 jun. 2014).

Todo esse processo, portanto, gera angústias em Celina. Por se sentir só na tarefa de educar, sem o apoio da família, a professora carrega para si tarefas que estão além da educação formal, como ensinar higiene pessoal e boas maneiras à mesa. É nesse âmbito que a família se torna seu grande alvo de críticas:

Eu aproveitei a aula dela [professora que desenvolve um projeto de valores na escola], quinta-feira, que era de boa alimentação, e levei 
um café da manhã. Comprei bolo, comprei pão, bolacha, suco, comprei uma caixa de suco, e pedi para eles levarem uma fruta picada dentro de uma tupperware e o lanche que eles queriam, que nós íamos fazer uma alimentação dentro da sala [...]. Até isso eu estou trabalhando, porque a criança não senta numa mesa com o pai e a mãe para comer. Será que o pai nunca viu o filho socar a banana na boca e amassar com a mão para engolir mais rápido? [...] Então, isso não é responsabilidade da escola, ensinar como sentar à mesa e comer. Sabe? Mastigar com a boca fechada... eles engolem. Tem criança que lá que, você vê, ainda mama na mamadeira. Com 9 anos, eu tenho aluno que mama na mamadeira. Será que a mãe não percebe? (Entrevista, 13 jun. 2014).

Em relação ao comprometimento com a ação educativa, é interessante mencionar que Celina foi a única professora que aplicou seu projeto elaborado para o GDE, o qual foi denominado Vamos brincar? Brincar de quê?. No exame do material produzido pelas professoras na plataforma Moodle, constatei que o intuito do projeto de Celina e de sua parceira (a atividade foi realizada em dupla) era questionar os processos de socialização de meninos e meninas. O projeto propunha a leitura de um livro de Ruth Rocha, Faca sem ponta, galinha sem pé21 (1999), a fim de refletir sobre as diferenças de gênero nas brincadeiras infantis. Para tanto, na apresentação das atividades, a dupla proponente descrevia que, após a leitura do livro, as crianças seriam solicitadas a se imaginarem passando por baixo de um arco-íris e, em seguida, inverteriam seus papéis: por exemplo, meninos brincariam com bonecas e meninas jogariam bolinhas de gude. Após refletirem sobre a experiência de trocarem os papéis, os(as) alunos(as), em conjunto com as professoras, produziriam um texto coletivo e construiriam brinquedos a serem socializados entre meninos e meninas.

Durante a entrevista, perguntei a Celina sobre a aplicação do projeto, sobre sua execução e seus resultados. A professora, entretanto, alegou não se lembrar muito do desenvolvimento da proposta, o que a impediu de narrar a experiência com detalhes. Conforme a entrevista se desenrolou, porém, ela se lembrou de que a aplicação do

\footnotetext{
${ }^{21}$ No livro Faca sem ponta, galinha sem pé (1999), Ruth Rocha conta a estória de dois irmãos, Pedro e Joana. Pedro implicava com Joana por fazer coisas de menino e Joana com Pedro por fazer coisas de menina. Ao passarem sob um arco-íris, Pedro transforma-se em Joana e Joana em João. A partir daí ambos vivem na pele o dilema de fazerem o que têm vontade, mas sem serem questionados por não corresponderem aos papéis sociais direcionados aos meninos e às meninas.
} 
projeto teria se dado no mesmo período em que a escola oferecera uma palestra sobre gravidez na adolescência.

Penso que a atitude de Celina ao aplicar o projeto proposto no GDE, bem como toda sua preocupação referente à aprendizagem de seus(as) alunos(as), tenha haver, em certa medida, com o que Cláudia Vianna (1998) assinala sobre a paixão presente no ato de lecionar. Em outras palavras, mesmo que Celina esteja desencantada com a docência, sua responsabilidade em relação às crianças e seu comprometimento para que os(as) alunos(as) tenham uma aprendizagem significativa demonstram interesse na ação educativa, visto que ela procura aprender e fazer o seu melhor para que as crianças aprendam, seja no nível formal - saber ler e escrever -, seja no informal - portar-se à mesa e saber higienizar-se.

Outro interessante episódio relatado pela entrevistada diz respeito a uma intervenção sua quanto às questões de sexualidade e relações de gênero em uma aula de higiene, o que ocasionou certo desentendimento com um dos pais de seus(as) alunos(as).

Eu dei uma aula de higiene pessoal, nos órgãos genitais das crianças, porque eu não aguento o cheiro de vagina e pênis de manhã, um cheiro horrivel [...]. O pai foi reclamar, foi reclamar de mim para a coordenadora, porque eu falei. Só que o aluno falou em termos vulgares para o pai, entendeu? Mas eu não falei em termo vulgar, eu falei que o pênis tem que ser puxado, lavado, limpo, para não ter um cheiro, e a vagina também [...]. Aí ele ficou meio assim, mas ele aceitou a minha explicação. E eu estou batendo nessa tecla, sabe?, porque é muito desagradável, é um cheiro horrível. Isso você percebe que é falta mesmo de zelo (Entrevista, 13 jun. 2014).

Tal acontecimento revela dois aspectos importantes da compreensão de Celina como mulher e professora. Em primeiro lugar, trata-se da forma como ela, como mulher, entende a sexualidade, isto é, por um viés higienista, em que o sexo, além de vergonhoso e privado, como ela mesma já relatou, é também algo sujo. Daí a explicação de todo o seu bloqueio ao falar de sexualidade, seja com as amigas, seja com os(as) alunos(as). Em segundo lugar, por mais que haja entraves na efetivação de uma educação sexual na escola, ela, como professora, manteve-se firme em sua posição, uma vez que não se resignou ao pai do aluno que, no fim das contas, acabou por 
compreendê-la. Esse último aspecto, por sua vez, indica seu comprometimento com a aprendizagem dos(as) alunos(as).

Foi justamente nesse cenário que Celina fez menção ao GDE, o que me levou, portanto, a interrogar sobre sua participação no curso, a qual, segundo seus relatos, foi estimulada pela vontade de aprender. Suas falas sobre o GDE remetem, já em seus discursos na plataforma Moodle, à revisão de valores, aos questionamentos de sua conduta e ao reconhecimento da diversidade presente em práticas e desejos sexuais:

Como grande parte das mulheres de gerações passadas, fui submetida, desde a tenra infância, para ser "boazinha" e a concordar com tudo (Atividade do módulo 2, 24 fev. 2010).

Sofri muito para elaborar o memorial e até mesmo alguma atividade, eu tive muita dificuldade. Não tinha o hábito de relatar fatos, muito menos de me expressar, mas posso garantir que adquiri o hábito de ler e relatar mais, policiar-me nas minhas falas, de ser mais tolerante, observar ao meu redor e perceber que há muitos preconceitos e preconceituosos nítidos, os quais nunca reparei. Será que eu não fiz parte de um deles? (Memorial, 21 abr. 2010).

[...] eu comecei a pesquisar sobre algumas coisas, a ir atrás mais de informações, entendeu? Porque, para mim, como eu fui criada muito fechada, sexo para mim era só aquelas determinadas coisas, entendeu? E hoje analiso. Depois que eu fui pesquisando, eu percebi que tem outros estilos (Entrevista, 13 jun. 2014).

Em um primeiro momento, os relatos de Celina indicam sua dificuldade em falar de um tema por ela considerado íntimo. Entretanto, ao aprender sobre a historicidade da sexualidade e das relações de gênero, bem como ao questionar-se acerca de seu comportamento como sujeito, ela passou a refletir sobre a presença de preconceitos quanto ao sexo e ao gênero. A perspectiva histórico-sociocultural em relação a essas temáticas, por conseguinte, produziu certo desconforto à professora, mas também muita reflexão. A característica reflexiva do GDE também é ressaltada por Célia Rossi et al. (2012, p. 21):

[...] parece ter mexido com as estruturas, conceitos e até mesmo valores internalizados pelos/as professores/as sobre as temáticas da sexualidade e diversidade sexual, que puderam ser desvelados dentro de uma perspectiva histórica-sociocultural. Grande parte dos/as professores/as, que não haviam tido acesso ao conhecimento sobre diversidade sexual em sua formação inicial, tiveram a oportunidade de, via formação continuada, conhecer, discutir, refletir e inquietar-se com a temática. 
Diante de tudo o que foi exposto, pode-se perceber que o entendimento de Celina sobre o que é ser mulher está centrado no comportamento recatado da figura feminina. Porém, ao participar do GDE e entrar em contato com a visão histórico-sociocultural sobre sexualidade e relações de gênero, a professora passou a questionar seus valores como mulher, bem sua percepção sobre diversidade sexual.

Tais questionamentos e reflexões, no entanto, ficam mais restritos ao âmbito pessoal da vida da entrevistada. Como professora, embora apresente muito desencanto com a profissão docente, ela luta pela efetivação de uma aprendizagem significativa a seus(as) alunos(as), o que se torna visível, por exemplo, em seu comprometimento em pesquisar e aprender os temas do GDE, bem como em aplicar esse conhecimento por meio de um projeto elaborado por ela ao final do curso. Todavia, seus processos de socialização em relação ao que possa ser definido como mulher, os quais a fazem compreender a sexualidade como algo privado e sujo e o sujeito feminino como alguém recatado e contido, impediram-na de realizar aulas críticas e reflexivas sobre sexualidade e relações de gênero, limitando sua fala e sua ação pedagógica às questões da diversidade sexual na escola.

\subsection{Helena: "Eu falo que na próxima encarnação eu quero ser homem..."22}

Helena tem 42 anos. Nasceu na cidade de São Paulo e aos 15 anos mudou-se com a família para São José do Rio Preto, onde já está há 27 anos. Desde o início de nosso contato, ela foi bastante solícita. Nosso encontro se deu durante um café da tarde preparado por ela em sua casa, regado por suas lembranças sobre a infância vivida em São Paulo.

De modo um pouco tímido, mas concentrado, ela deu início à conversa contando que, apesar de algumas limitações devido à violência que já assolava a capital, divertiu se muito brincando na rua. Era a ida a Promissão (SP), cidadezinha vizinha de SJRP, no entanto, que tornava sua infância um momento especial, já que visitava a casa da avó, dos(as) tios(as) e brincava com seus(as) primos(as).

\footnotetext{
${ }^{22}$ Entrevista realizada em 13 de junho de 2014.
} 
Ela e suas três irmãs tiveram pai contador e mãe professora. Com esta, Helena tinha um bom relacionamento; com o pai o mesmo não ocorria, já que com ele ela mal conversava. Sempre muito rígido na educação das filhas, ele não a deixava ter amizade com meninos, assistir a novelas, nem andar descalça. A postura de seu pai evocava medo tanto nela e em sua irmã mais nova, quanto em sua mãe; sua irmã mais velha, porém, sempre o enfrentava.

Em relação à relação conflituosa com o pai, Helena narra que, certa vez, sua irmã mais velha queria comer coxinhas e pediu insistentemente para sua mãe. Vendo a insistência da menina, o pai pediu à esposa que fritasse todas as coxinhas disponíveis e fez a garota comer tudo contra sua própria vontade: “Eu fiquei, sabe?, com aquilo: ela não conseguia mais, e ele fazia comer. Então, as coisas que ele judiou, assim, nela, então, assim, me marcaram” (Entrevista, 13 jun. 2014).

De fato, o medo do pai é marcante no discurso de Helena. Sua obediência se mostra como uma resposta ao medo da violência, ou, em outras palavras, o medo de criar desavenças e de apanhar leva a filha a acatar as ordens do pai severo. Assim, a obediência e o medo funcionam como instrumentos de poder ${ }^{23}$ a serviço do controle do comportamento feminino em uma sociedade em que as relações de poder são desiguais, visto que se definem por um caráter patriarcal.

Por conseguinte, o pai e também o marido, assim como no caso de Gislaine, exercem domínio sobre os corpos e as vidas de suas filhas e esposas, uma vez que criam e veiculam estratégias de poder - como o ciúme, o medo e a violência - a fim de controlar as mulheres. É exatamente devido a essa estrutura de poder que Margarita Pisano (2004) afirma que o patriarcado, ao criar muros para manter sua soberania, encerra as mulheres na condição de mãe, esposa e filha:

Estos muros contienen la lógica de la guerra, están puestos en el juego de la toma y la defensa. La historia patriarcal es una historia de muros: el muro de Berlin, el muro de Río Grande, la Muralla China, los muros de los castillos. Unos más extensos que otros, unos más actuales que otros, pero todos encierran espacios de poder y dominación,

${ }^{23}$ Conforme já dito, na acepção de Michel Foucault (1985, p. 89-90), o poder "se exerce a partir de inúmeros pontos e em meio a relações desiguais e moveis". 
constituyendo modos de vida que responden a parcelaciones voluntariosas y hegemónicas de las potencias masculinas y sus interesses (PISANO, 2004, p. 45).

A adolescência de Helena foi vivida em SJRP, mas as visitas a Promissão (SP) eram frequentes. Foi justamente ali que ela conheceu seu marido, com quem está casada há 17 anos e tem um filho de 10 anos de idade.

Em relação à vida matrimonial, ela afirma possuir um bom relacionamento com o marido: ambos têm objetivos em comum e partilham dos mesmos interesses. Entretanto, quando explica o que entende por ser mulher, a conjugalidade adquire o peso de um cativeiro (RÍOS, 2005), visto que a liberdade lhe é negada em razão da dupla jornada de trabalho - no espaço público (no caso das mulheres desta pesquisa, a docência) e no espaço privado (o lar) -, realidade também enfrentada pela maior parte das mulheres em seus cotidianos.

Eu falo que na próxima encarnação eu quero ser homem [...]. Essa jornada aí que a gente tem que é muito grande, que hoje em dia a gente tem que trabalhar e, queira ou não, a maioria das coisas, mesmo o marido ajudando, né?, sobra para a mulher. Então, em relação a filho, as preocupações, eu acho que são diferentes do homem as preocupações. Então, por mais que o homem ajude, eu acho que a mulher tem muita, muita coisa para ela, né? Trabalhar, depois chegar, arrumar a casa, é comida, é tudo. Então, eu acho que é muito pesado ser mulher (Entrevista, 13 jun. 2014).

Diferentemente de Gislaine e Celina que enfatizam, respectivamente, a beleza e o comportamento recatado como características do feminino, Helena foi mais crítica em sua concepção sobre o que entende por ser mulher. Isso se deve ao fato de ela, ao perceber seu cativeiro -, isto é, as obrigações que se iniciam no trabalho e continuam em sua casa -, consegue reconhecer o peso de ser mulher em uma sociedade que, além de exigir da mulher uma atuação no espaço público, não deixa de lhe atribuir o cuidado da casa e dos(as) filhos(as). É justamente nesse âmbito que as relações conjugais reproduzem a cultura patriarcal:

El hecho distintivo de la participación de la conyugalidad en la recreación de ese mundo, es que implica a los sujetos desde la intimidad, para la sobrevivencia cotídiana, para toda la vida, a partir de 
las desiguales y assimétricas relaciones de dependência, sujeción y domínio que se estabalecen entre ellos (RÍOS, 2005, p. 438).

A postura crítica sobre o que é ser mulher é uma constante no relato de Helena, de modo que suas inquietações e indagações acerca das múltiplas funções que a mulher desempenha em sociedade e que são vistas como naturais podem ser identificadas no discurso dessa docente durante (participação na plataforma Moodle) e após o GDE (entrevista):

O machismo infelizmente continua existindo nas relações. As mulheres vítimas de agressão muitas vezes são vistas como culpadas, até mesmo no pensamento de outras mulheres. Por exemplo, nas novelas os homens podem trair suas mulheres, mas, quando acontece o contrário, a própria opinião pública fica inconformada com o ocorrido (Módulo 2, Fórum, 12 fev. 2010).

Então, pensei muita coisa depois: Porque que eu tenho que ser desse jeito? Então, isso é uma coisa imposta pela sociedade. Então, eu acho que isso que o curso me abriu, assim, a mente, para pensar diferente, né? Então, assim, eu era... Tá, eu gosto de arrumar a casa, tal, tal, tal. Mas por que só eu? Então, espera aí. Então, eu parei um pouco para pensar em outras coisas que antes eu não pensava [...]. Ai, porque que eu tenho que chegar, eu tenho que ver, por exemplo, o uniforme do meu filho, que eu tenho que ver se acabou o remédio, se não sei o quê, o cachorro, não sei o quê. Por que tudo eu, né? Eu fico pensando, mas eu não tenho, não consigo, assim, modificar isso. Mas os meus pensamentos ficam, assim: Nossa, que saco ser mulher (Entrevista, 13 jun. 2014).

Os relatos de Helena chamam atenção para dois fatos importantes: primeiro, o machismo internalizado nas atitudes e nos discursos das próprias mulheres; segundo, o fato de a participação no GDE tê-la feito pensar em sua condição como mulher, o que, até então, não lhe era questionável. Após fazer o curso, portanto, ela consegue reconhecer que certas atividades ditas femininas, como organizar a casa e cuidar dos(as) filhos(as), são construções sociais, uma vez que são socializadas e aprendidas pelas mulheres desde a primeira infância (BEAVOUIR, 1980). Ela reconhece que as diferentes formas de ser mulher fazem parte de um processo de aprendizagem contínuo, mas ao fim do depoimento admite dificuldades para modificar seu comportamento, embora discorde de suas próprias práticas e atitudes como mulher.

A criticidade da entrevistada sobre as questões sexuais e de gênero não está presente apenas em sua percepção sobre as diferentes formas de ser mulher, mas 
também no âmbito das diferentes formas de ser professora. Antes de expor seu entendimento a esse respeito, é válido apresentar sua formação acadêmica e profissional.

Durante o ensino médio, Helena fez magistério no CEFAM, curso ao qual deu início em São Paulo, mas concluiu em SJRP. Na condição de aluna, ela se descreve como organizada, responsável, comprometida, com notas boas e com facilidade para aprender.

A escolha de Helena pelo magistério se deu por influência - ainda que indireta de sua mãe, que também é professora. Mesmo sendo desestimulada pela mãe, devido à desvalorização docente, ela se interessou pela carreira, tomando-a como uma forma de se tornar financeiramente independente dos pais:

E aí surgiu o CEFAM... Aí eu queria um curso técnico, porque antes era assim: você acabava o magistério, então aí você já podia dar aula. Eu queria uma coisa, assim, que eu terminasse, que eu já podia ganhar dinheiro, tipo, para ser, assim, mais independente... Não depender do meu pai, sabe? Porque, como o meu pai era daquele jeito, eu não via a hora de ter o meu dinheiro, de não ter que pedir nada, ter um pouco mais de liberdade. Então, eu fui fazer o magistério, mas também por causa, assim... a minha mãe era professora... talvez, né? (Entrevista, 13 jun. 2014).

Em um primeiro momento, no entanto, a entrada de Helena no mercado de trabalho não foi via instituição escolar. Conforme explicou a docente, que se graduou em Educação Física em uma universidade particular, o início de sua carreira aconteceu na atuação em academias de ginástica. Somente em 2003, quando foi aprovada no concurso da escola do Serviço Social da Indústria (SESI), como professora de Educação Física, ela começou a trabalhar na área da educação.

Em seguida, passou nos concursos do Estado e da Prefeitura de SJRP, também para o cargo de professora. Começou a atuar na rede estadual, mas dela exonerou quando foi convocada pela Prefeitura, concentrando-se, então, na rede municipal e no SESI. Após o nascimento de seu filho, ela se desligou das atividades no SESI e passou a atuar somente na Prefeitura. Contabilizando 11 anos de magistério, Helena já ministrou aulas em Ensino Infantil, Fundamental e Médio. Atualmente, leciona no âmbito da Educação Especial. 
Quanto à formação acadêmica, além da graduação em Educação Física, ela cursou duas pós-graduações (lato sensu), sendo a primeira em Treinamento Desportivo, ainda quando trabalhava em academias, e a segunda em Educação Especial.

Quando questionada sobre o que entende por ser professora, Helena destacou o papel do(a) professor(a) no que tange ao desenvolvimento pedagógico e à transformação do(a) aluno(a):

Ser professora... Ai, é poder mudar um ser, assim, mudar... Ele chegar de um jeito e você deixa-lo de outro, sabe? Mas, assim, não no meu jeito, né? Mas tentar modificá-lo para melhor. Então, ensinar tudo o que eu puder, ensinar para que ele se desenvolva, né?, de uma maneira melhor, crescer [...]. Eu vejo assim. Professora: o meu papel é esse (Entrevista, 13 jun. 2014).

Sua concepção sobre o que é ser professora centra-se no aspecto cognitivo da criança. Para ela, o compromisso do(a) professor(a) está na modificação do(a) aluno(a). Consequentemente, a transformação suscitada pelo(a) professor(a) se dá por meio da aprendizagem e tem como objetivo obter a melhor versão do(a) educando(a).

Todavia, embora ela concentre o significado sobre o que é ser professora na aprendizagem, é possível notar em seus relatos que, para ela, a tarefa docente vai além do ensinar a ler, a escrever e a contar. Tal afirmação encontra respaldo no fato de Helena não estar alheia às questões sobre sexualidade e relações de gênero na escola, tampouco a todo o senso comum e ao preconceito que giram em torno dessas temáticas.

Foi justamente nesse cenário que a entrevistada, com o semblante incrédulo, relatou o período em que lecionou, na Educação Infantil, para um aluno que possuía trejeitos femininos. Segundo ela, tal aluno era alvo de mais comentários por parte dos(as) professores(as) e dos(as) funcionários(as) da escola do que dos(as) próprios(as) colegas. Ao exemplificar o tipo de comentário que surgia naquela situação, a professora conta:

Em relação ao Francisco, que era o pequenininho: "Ai, mas a mãe, a mãe dele sabe disso?" [...]; "Ai, e o pai? O que vai fazer"; "Olha, se começar assim, esse menino vai, vai virar bicha”. Então, sempre a gente ouve por parte dos outros, esse preconceito (Entrevista, 13 jun. 2014). 
De acordo com Helena, o referido aluno também gostava de vestir fantasias femininas e isso incomodava as outras crianças, que não entendiam como um menino podia gostar de usar coisas de meninas. A professora, no entanto, procurava reforçar que aquela postura era uma questão de preferência e que, se os outros meninos quisessem, também poderiam experimentar as fantasias femininas. O mesmo valia para as meninas em relação às fantasias masculinas:

[...] na hora da fantasia, ele gostava de colocar fantasia de menina, $e$ eu não falava que não. Era a preferência dele. Eu explicava para os outros: ele gosta. Porque ai as outras crianças falavam: "Mas isso é de menina. É de menina", para ele [...]. E ele na dele. E eu explicava para a classe: "ele gosta, porque chama a atenção, né? Está chamando a atenção dele, se você quiser pôr, você pode pôr também". [...] Então, assim, não via problemas. Então, eu explicava que não tinha nenhum problema em colocar. Então, ele colocava, na hora da fantasia, o vestidinho, porque ele gostava que rodava, assim, aqueles tules, aquele monte de tule, e aí o pessoal ficava meio que assim, sabe? (Entrevista, 13 jun. 2014).

Helena explicou que procurava tratar a criança de maneira a que ela não percebesse os olhares preconceituosos. Disse que já havia conversado com a mãe da criança e que esta também não via problemas no uso da fantasia feminina. A criança, por sua vez, não percebia o preconceito:

[...] a mãe dele sabia que ele gostava. Falei com a mãe, não tinha problema nenhum. Acho que uma coisa não tem nada a ver com a outra, tanto pela idade também, 4 anos [...]. Eu fazia de tudo para não perceber nada. Então, ela não percebeu, porque ela não se retraiu, $e$ ela continuou das outras vezes também a querer pôr a fantasia (Entrevista, 13 jun. 2014).

Já em relação ao preconceito dos adultos, a entrevistada afirmou ter tido de intervir por meio de uma conversa com a coordenadora da escola:

[...] elas ficavam olhando, as funcionárias, né?, lá do Francisco, que era pequenininho, 4 anos, com a fantasia. Elas paravam para olhar, $e$ ficavam fofocando, falando. Então, eu falei para a coordenadora que eu não estava gostando. Então, aí, ela, a coordenadora, falou com as funcionárias para não intervir, não ficar olhando, falando, porque era uma coisa normal, e tal, e para parar com aquilo, para pôr um ponto final (Entrevista, 13 jun. 2014). 
Para além desse episódio, ela disse já ter presenciado outros em relação às manifestações de sexualidade e relações de gênero nas escolas em que lecionou. Deparou-se, por exemplo, com uma situação em que, perante um aluno que tinha o cabelo comprido e gostava de dançar, alguns(as) professores(as) diziam, com ar malicioso: "Ai, aquele menino daquele jeito, eu vou pegar aquele cabelo e vou cortar!". Ou, então, na Educação Infantil, presenciou um contexto em que uma menina gostava de dar as mãos ao amiguinho e dizia que era sua namorada, enquanto os(as) funcionários(as) da escola e os pais das crianças olhavam para aquela situação como se fosse algo pervertido. Em alguns desses casos, Helena chegou a se posicionar, mas, diante da resistência das pessoas, foi desistindo de fazê-lo: "Para algumas pessoas, eu explicava; para outras, eu acho que era perda de tempo" (Entrevista, 13 jun. 2014).

A partir de tais relatos, questionei a professora sobre sua participação no GDE. De acordo com ela, a familiaridade com os temas foi o que pesou em sua decisão de fazer o curso. O uso da palavra familiaridade confirma, portanto, sua postura de interesse em relação aos episódios anteriormente relatados, visto que ratifica sua proximidade com as questões que envolvem a sexualidade e as relações de gênero na escola: "E aí, a Secretaria estava oferecendo esse curso. Falei: Ah, eu vou fazer. Achei também o título e, né?, me familiarizei. Eu falei: Ah, eu vou, eu vou fazer" (Entrevista, 13 jun. 2014).

Em relação ao projeto intitulado Meu corpo, que tinha como objetivo estimular o conhecimento da dimensão corporal em seus aspectos biológicos, psicológicos e sociais, Helena não o aplicou devido a uma mudança de escola que coincidiu com sua participação no GDE. A entrevistada destaca, porém, que o curso lhe proporcionou um novo olhar sobre a sexualidade e as relações de gênero na escola, o que se confirma quando ela cita novamente o episódio do aluno que gostava de vestir fantasias femininas. Diante desse caso, a professora afirma a importância de se considerar a diversidade sexual:

Eu acho que contribuiu, porque tudo o que a gente aprende eu acho que contribui. Contribui, assim, um novo olhar. Por exemplo, eu fiz esse curso antes de eu dar aula para o menininho, de 4 anos, né?, no Jardim I. Então, eu tive outro olhar em relação a isso, eu levei numa boa, como normal. Então, assim, eu acho que sim, que abriu mais a minha mente para isso. Como fala? Ah, que a diversidade existe e que a gente tem que respeitar, né? (Entrevista, 13 jun. 2014). 
Helena afirma que o curso a ajudou a pensar em sua conduta dentro da sala de aula. Nesse sentido, ela menciona a prática de fazer fila para meninos e fila para meninas, questionando a segregação do masculino e do feminino na escola:

É, eu comecei a refletir mais, né?, da minha postura diante dessas questões, tanto de sexualidade, como essas diferenças de gênero. Então, fazer uma fila de menino e de menina, para quê? Eu não faço, eu não gosto de fila [...]. Então, antigamente, assim, né?, no começo, você vê todo mundo fazendo, você faz igual, não sabe nem porque que está fazendo [...]. Então, assim, para quê? Por que separar? Então, eu não. Lá mesmo, no Jardim, eu não gostava de fila: "Dá a mãozinha para o amigo, o amigo que você quiser; se menino quer dar a mão para menino, dá; se menino quer dar a mão para a menina, dá”. E vamos para frente, e aí é andando sem fila [...]. É. Abriu a mente: Para que fila de menino e menina, por exemplo? (Entrevista, 13 jun. 2014).

Ela também faz críticas ao curso GDE, ao afirmar que não gostou de um filme exibido durante o Módulo 3 (Sexualidade e Orientação Sexual): Kinsey: vamos falar de sexo (2003). Em sua opinião, o filme subtende a normalidade da prática sexual infantil:

[...] pelo filme, deu a entender que ele era a favor da... como fala? Das crianças fazerem sexo, sabe? Não lembro agora o nome. São fatos reais, tudo de um estudioso [...]. Eu não gostei porque, assim, eu não acho normal, né: Então, estava colocando, assim, como normal, e eu não acho normal, porque a nossa sociedade que colocou isso, que isso não pode, mas que pode. É isso que, mais ou menos, o filme quis passar, né? E que isso é normal [...]. Eu não me identifiquei com isso (Entrevista, 13 jun. 2014).

O filme em questão narra a vida e a obra de Alfred Charles Kinsey, biólogo, sexólogo e professor que, em 1947, fundou o Instituto de Pesquisa do Sexo na Universidade de Indiana (EUA), posteriormente conhecido como Instituto Kinsey para a Pesquisa do Sexo, Gênero e Reprodução. Kinsey foi um estudioso do comportamento sexual e, para tanto, realizou pesquisas com mulheres e homens americanos.

Para ele, "aquilo que usualmente era considerado anormal, no que diz respeito à sexualidade humana, não era tão anormal de fato" (VIEIRA, 2014, p. 695). Nesse sentido, sua teoria aponta que toda atividade sexual é natural, inclusive aquelas que são culturalmente reprimidas, como o sexo com animais, entre pessoas do mesmo sexo e com crianças, sendo esta última o alvo da crítica de Helena. 
É preciso destacar que o propósito, aqui, não consiste em apresentar um aprofundamento das ideias de Kinsey, tampouco criticar a exibição do filme durante o curso, mas sim entender quais seriam as melhores estratégias para alcançar os objetivos de um projeto que prioriza a educação para a diversidade. Embora a teoria de Kinsey faça parte de uma sexologia preocupada com as estatísticas e os padrões normativos, é positiva sua contribuição quanto à desmistificação das práticas sexuais no que tange aos padrões culturais (VIEIRA, 2014). Todavia, será que a menção a tais ideias seria a melhor tática para se discutir o peso da cultura sobre a sexualidade? Se sim, qual terá sido a falha na comunicação entre os(as) responsáveis pelo curso e os(as) cursistas, tendo em vista que o objetivo atribuído à exibição do filme não surtiu o efeito desejado? Se não, quais estratégias seriam mais viáveis a fim de compreender a relação da sexualidade com os aspectos sociais, culturais, históricos e políticos? Tais questões nos fazem enxergar, portanto, a presença de lacunas no GDE, bem como a importância de que algumas metodologias do curso sejam revistas.

O perfil de Helena evidencia que ela não está alheia às questões referentes à sexualidade e às relações de gênero, tanto no que diz respeito às diferentes formas de ser mulher, quanto no que diz respeito às diferentes formas de ser professora. Durante seus relatos, foi possível perceber que ela é ciente de que o modo padrão de definir o que é ser mulher em uma sociedade patriarcal é uma condição árdua. Já como professora, Helena demonstra estar atenta às manifestações de sexualidade e relações de gênero na escola, intervindo, muitas vezes, de forma reflexiva sobre os casos que presenciou.

Nesse sentido, sua participação no GDE consistiu mais em uma afirmação do que ela já pensava e vivia, do que propriamente na aprendizagem de algo novo. Por mais que Helena vivencie e se renda às amarras do patriarcado - uma vez que, mesmo não notando, frequentemente exerce papéis socialmente destinados às mulheres -, ela consegue resistir à cultura patriarcal por meio da criticidade que foi construindo, dia a dia, a partir de sua atuação como mulher e professora. 


\subsection{Bianca: "[...] ser professora... Eu penso: 'sou eu', 'esta sou eu"»24}

Bianca nasceu em Urupês (SP) em 1967. Aos 2 anos de idade, mudou-se, com sua família, do sítio para a cidade de Irapuã (SP), a 55 quilômetros de São José do Rio Preto. É naquele município que ela permanece até hoje.

A entrevista com Bianca, que então contava 48 anos, realizou-se no estabelecimento comercial de seu marido. Em alguns momentos, nossa conversa foi interrompida por pessoas que chegavam e a cumprimentavam. Mesmo com tais interrupções, ela manteve o foco na entrevista, respondendo com entusiasmo às questões que eu lhe apresentava. Ao entusiasmo somava-se seu bom humor, muito presente em nossa conversa.

O relato teve início por suas lembranças da época em que era criança. Sua infância, segundo ela, teve altos e baixos no quesito financeiro; ainda assim, ela considera ter sido muito feliz. De família numerosa, é a caçula entre sete irmãos (dois homens e cinco mulheres). Tanto seu pai quanto sua mãe criaram os(as) filhos(as) na base do diálogo, sendo todos os conflitos familiares resolvidos na conversa. O pai, já falecido, não era de beijar e a abraçar os(as) filhos(as), mas sempre demonstrou carinho. Todavia, Bianca relata ter uma ligação mais forte com a mãe, a quem até hoje confidencia toda sua vida. Durante a entrevista, tornaram-se evidentes seu amor e sua admiração por seus pais e seus(as) irmãos(ãs).

Ainda no que se refere às primeiras fases de sua vida, ela recorda de um fato marcante: quando sentiu ciúmes e solidão diante do nascimento de seu primeiro sobrinho, afinal, todas as atenções da família se voltaram para o bebê. Para ela, que até então havia sido a caçula dos sete irmãos, aquele representou o momento mais difícil de sua infância.

Durante a adolescência, Bianca cursou o magistério, algo muito valorizado por seus pais, que possuíam somente o ensino fundamental incompleto. Sua mãe lê e escreve bem, mas seu pai tinha muitas dificuldades, tanto na leitura quanto na escrita.

\footnotetext{
${ }^{24}$ Entrevista realizada em 14 de junho de 2014.
} 
Para ele, ter filhos(as) professores(as) era razão de imenso orgulho: além de Bianca, duas de suas filhas também são docentes e outras duas trabalham em escolas.

Ao final do magistério, Bianca foi morar com sua irmã em Brasília (DF) para ajudá-la com o filho pequeno. A ida para a capital também teve como motivo uma paixão não correspondida.

[...] um dos motivos também do convite da minha irmã foi esse, que ela me sentia muito envolvida numa pessoa que não tinha o valor que eu deveria ter. Então, um dos motivos, também, foi para que eu saísse daqui, para que eu esquecesse. Aí namorei bastante lá, mas tudo que eu namorava... Não, não fazia sentido, ele era muito forte na minha vida (Entrevista, 14 jun. 2014).

Permaneceu em Brasília por três anos, mas nada por lá parecia engrenar. Foi então que resolveu voltar a Irapuã (SP) e ali conheceu seu marido, com quem está casada há 24 anos e tem três filhos: uma menina (já adulta) e dois meninos (um adulto e outro ainda criança).

Segundo ela, tanto a primeira quanto a segunda gestação foram planejadas. A terceira, no entanto, foi uma surpresa, pois engravidou aos 42 anos de idade, logo após a morte de seu irmão. Mas foi justamente a novidade de um bebê que tirou a família da tristeza.

O relato da chegada do terceiro filho demonstrou toda a disposição de Bianca, pois ela já possuía dois filhos adultos e, ao se ver novamente grávida, teve de dedicar-se mais uma vez à maternidade. Aí também se evidenciou sua concepção sobre o que é ser mulher, visto que, ao comparar sua atuação como mãe à de seu marido como pai, ela percebe, assim como Helena, todo o peso advindo das responsabilidades socialmente destinadas às mulheres:

Eu acho que tudo para o homem é mais fácil. Ele tem uma profissão, ele vai se dedicar à profissão dele e ele vai chegar lá e o pouquinho que ele fizer em casa está bom para ele. Ser mulher é tudo, é um acúmulo de tudo, é tudo para você, eu acho. Eu vejo, por exemplo, às vezes, o meu marido sair com o meu filho pequenininho, sair, levar para algum lugar, ou a gente está numa festa, eu estou dançando, alguma coisa, ele está com o meu filho, sempre tem alguém para falar: "Olha que lindo. Olha como ele cuida". E quando você está? Ninguém vai falar: "Olha, que mãezona" [...]. Então, o peso é muito, o peso 
para a mulher é muito, ela é responsável por tudo (Entrevista, 14 jun. 2014).

É a partir da experiência do casamento e, mais especificamente, da terceira vez em que se tornou mãe que Bianca experiencia, na terminologia de Ríos (2005), o cativeiro mãelesposa em torno da figura feminina. Nesse sentido, sua fala indica que, para ela, ser mulher é dividir-se entre ser mãe, dona de casa e profissional:

Ser mulher, para mim, é acúmulo de função. É você trabalhar profissionalmente, ter a sua profissão, é você cuidar da sua casa, é você cuidar do seu filho, é você cuidar do seu marido, é você cuidar de você mesmo. É tudo, é um acúmulo de coisa, eu acho (Entrevista, 14 jun. 2014).

A dupla jornada de trabalho citada pela entrevistada tem como figura central a mulher que saiu para o mercado de trabalho, mas que, ao mesmo tempo, não deixou de ser mãe e esposa. Todavia, apesar de esse discurso indicar o quanto tal jornada é cansativa, sua fala também revela possibilidades na desconstrução de estados e funções naturalmente atribuídos às mulheres. Isso pode ser notado, por exemplo, quando Bianca, após denunciar o cativeiro engendrado pelo casamento e pela maternidade às mulheres, questiona o restrito - porém aceito e normal - exercício da paternidade.

É interessante mencionar que seus questionamentos sobre as diferentes formas de ser mulher podem ser encontrados já em sua participação na plataforma Moodle durante o curso GDE. Em um dos fóruns do Módulo 2 (Gênero), Bianca demonstra seu sentimento de indignação ao assistir ao vídeo Escritos Milenares ${ }^{25}$

Senti muita indignação ao ler os Escritos Milenares e parar para pensar que ainda hoje, mulheres vivem em situações parecidas de forma aberta ao mundo ou mesmo de maneira velada como são muitos casos que conhecemos [...]. Sinto que o mundo mudou (para a maioria de nós mulheres), mas ainda assim existe uma perca muito grande do sexo feminino na relação "homem", "mulher". Sempre teremos que nos desdobrar mais e cobrar menos. Por mais que aconteçam mudanças jamais estaremos em condições de igualdade com "eles".

\footnotetext{
${ }^{25}$ A transcrição do vídeo Escritos Milenares encontra-se no anexo A.
} 
Mas, por estar vivendo um momento tão mágico - a maternidade - eu me vingo por saber que eles nunca serão mães (Fórum, 27 fev. 2010).

O vídeo mencionado pela professora apresenta slides com citações de documentos e de pessoas influentes na história em relação à percepção do feminino ao longo do tempo. Tal como é perceptível, o material causou certo incômodo em Bianca: seu sentimento de indignação é gerado quando ela nota - pois também o sente em sua vivência como mulher - a persistência de situações e discursos violentos e preconceituosos em relação às mulheres.

É interessante destacar como Bianca manuseia a condição de ser mulher. Mesmo indignada, tanto com os discursos machistas do vídeo, quanto com a dupla e cansativa jornada do trabalho feminino, a docente utiliza-se do cativeiro (RÍOS, 2005) da maternidade para mostrar que as mulheres também possuem algum tipo de poder em relação aos homens. Em outras palavras, para ela, por mais que os homens detenham melhores posições e privilégios na sociedade, existe algo que eles jamais poderão ter: a experiência de gerar e parir um(a) bebê.

De certa forma, seu discurso indica resistências aos imperativos patriarcais, já que admite outra forma de poder e o associa à mulher. É justamente nesse contexto que se faz necessário considerar, como nos lembra Foucault (1985, p. 91), que "lá onde há poder há resistência e, no entanto, (ou melhor, por isso mesmo) esta nunca se encontra em posição de exterioridade em relação ao poder". Isso quer dizer que o poder, nas sociedades modernas, é intrínseco a qualquer tipo de relação (econômica, de conhecimento, sexual etc.), estando presente em toda a malha social. Por conseguinte, Foucault explica que o poder não deve ser entendido como algo que vem de cima para baixo, mas como situação estratégica positiva (porque se manifesta de maneira imperceptível) e produtiva (pois se configura de forma múltipla, heterogênea e móvel).

Considerando que "não há, no princípio das relações de poder, e como matriz geral, uma oposição binária e global entre os dominadores e os dominados" (FOUCAULT, 1985, p. 90), a fala de Bianca ganha um novo sentido, já que, de uma maneira ou de outra, revela resistências perante o patriarcado. Estas podem ser percebidas, por exemplo, como já citado anteriormente, quando ela questiona o pouco envolvimento dos homens na criação dos(as) filhos(as), comportamento valorizado pela 
sociedade, ao passo que, para as mulheres, o cuidado integral das crianças é uma obrigação; ou então quando usa a capacidade de gerar e parir, característica biológica da fêmea, como uma forma de protagonismo feminino, conferindo, assim, empoderamento às mulheres.

Embora o vídeo Escritos Milenares assinale uma perspectiva para o entendimento do patriarcado e tenha causado indignação em Bianca, destaco a importância de se pensar esse material de modo análogo ao que foi direcionado ao filme sobre o sexólogo Kinsey. A utilização desse material, com frases soltas e excertos de textos, pode ser um tanto quanto tendenciosa, já que, além de reduzir a importância histórica de determinados pensadores, como Martinho Lutero (1483-1546), também sujeita as mulheres à condição de submissão e subordinação aos homens.

Ou seja, não se trata de negar o quanto as mulheres foram subjugadas (e como foram!), mas sim de procurar entender sua atuação na história, isto é, o quan to lutaram e resistiram bravamente ao poder engendrado pelos imperativos da sociedade patriarcal.

Várias mulheres resistiram ao poder masculino ao longo da história, dentre as quais é possível citar alguns exemplos: se recorrermos às narrativas acerca das origens, Lilith, a primeira mulher de Adão, exigiu mudanças em seu relacionamento para também usufruir de prazer no ato sexual; Safo de Lesbos (aproximadamente 590 a.C.), poetisa grega e importante representante da lírica grega, encantou as jovens com seus versos, tornando-se símbolo da homossexualidade feminina; entre as grandes rainhas, Cristina da Suécia (1626-1689), ambiciosa por conhecimentos, sobretudo aqueles proporcionados por René Descartes, e questionadora da doutrina luterana, queria fazer da Suécia a Atenas do Norte europeu, o que a levou a incentivar, em demasia, o desenvolvimento do saber e das artes em seu país; e, como já mencionado, Simone de Beauvoir (1908-1986), escritora francesa autora de Segundo sexo (1980), obra que, ao denunciar a servidão feminina, tornou-se um clássico dos estudos feministas (ROBLES, 2006). ${ }^{26}$

\footnotetext{
${ }^{26}$ Procurei destacar alguns nomes de mulheres que tiveram importância na história e que aparecem mencionadas na obra Mulheres, mitos e deusas: o feminino através dos tempos, de Marta Robles (2006). Obedecendo a uma cronologia histórica que se inicia na Antiguidade e vai até a Modernidade, a autora
} 
Nesse sentido, o uso do vídeo Escritos Milenares durante o curso pode ser questionado, afinal, a escolha desse material ilustrativo demonstrou a falta e, ao mesmo tempo, a importância de uma base contextual que tenha como referência as pesquisas científicas nas áreas da história e das ciências sociais. Por mais que os(as) cursistas tenham discutido o vídeo nos fóruns e nas tarefas propostas, a versão da história que predominou foi a mais pessimista em relação às mulheres, ou seja, a da subordinação feminina. É diante dessas lacunas que talvez seja necessário repensar alguns materiais e algumas das metodologias utilizados no GDE.

Quanto à formação acadêmica e à atuação profissional, Bianca, além do magistério, é formada em Pedagogia e pós-graduada (lato sensu) em Psicopedagogia. Leciona há 25 anos em Irapuã, dos quais 2 foram pela Prefeitura e 23 pelo Estado de São Paulo. Sempre atuou como professora da $1^{\text {a }}$ série do Ensino Fundamental.

O magistério não foi sua primeira opção de carreira. Seu sonho era ser médica veterinária, porém suas condições financeiras não lhe permitiram. Diante de suas possibilidades, relativamente à distância e ao custo, ela optou pelo magistério, o que, no fim das contas, acabou se transformando em uma grande paixão:

Fazia o magistério. Na época, até que eu comecei a fazer o magistério, foi, assim, uma falta de opção, realmente foi isso. Nós morávamos aqui, não tinha, na época, hoje em dia tem ônibus que leva até Rio Preto [...]. Na época da minha adolescência, faculdade era, assim, um sonho para quem tivesse dinheiro. Então, foi mesmo assim, um caminho que eu achei. O magistério foi uma saída, não foi, no primeiro momento, uma opção de vida. Aí, depois, logo que eu me formei, eu já comecei a dar algumas aulas [...]. Me chamavam para uma aula aqui, outra ali. E aí eu comecei, realmente, a gostar, eu senti que gostava, e eu senti que não era só uma falta de opção, comecei a gostar realmente. Amo o que eu faço, de verdade mesmo. Estou quase para me aposentar e gosto muito. Mas, na época, na adolescência, foi assim, tá? (Entrevista, 14 jun. 2014).

Pude perceber, em sua fala, a satisfação pela docência. O entusiasmo dessa professora ao relatar sua atuação em sala de aula ficou nítido durante todo o tempo em

discute a condição da mulher em nossa sociedade, destacando a história de vida de personalidades femininas marcantes. Dentre estas, as que aqui aparecem citadas foram selecionadas conforme minha preferência e identificação. 
que estive com ela. Ao ser questionada sobre o que é ser professora, ela imediatamente ressaltou o gosto por lecionar, ação que, apesar de difícil, é para ela motivo de grande realização pessoal e profissional:

[...] ser professora... Eu penso: "sou eu", "esta sou eu”. É onde eu faço realmente o que eu gosto de fazer [...]. Às vezes, eu saio dali, eu vou para casa... Eu não gosto de fazer isso, eu não gosto de fazer aquilo, eu não gosto disso e daquilo. E ali eu gosto, embora seja difícil, seja complicado. Hoje em dia é muito complicado, as crianças estão muito... mas eu gosto. Então, eu não consigo me imaginar, Bianca e professora, assim, duas coisas distintas. Para mim, sou eu [...]. Então eu me encontro, esta é o que eu gosto, é o que eu sou. Agora, não sei quando eu deixar de ser, como é que vai ser, né? Eu me sinto bem, você entendeu? Me sinto assim, parece que aí eu vou colocar alguma coisa para alguém, eu vou colocar assim, é uma coisa que eu faço bem feito, é uma coisa que eu gosto de fazer, é uma coisa que me realiza. Então, eu me sinto, assim, bem integrada ali comigo mesma (Entrevista, 14 jun. 2014).

É também perceptível a separação que ela estabelece entre o gosto por ensinar e as dificuldades em torno do que é ser professora. Justamente nesse sentido, o carinho dos(as) alunos(as) aparece como a maior recompensa no seu ser professora:

Olha, a coisa mais gostosa do mundo é o carinho. É eu sair, que nem, nas férias, e passar em algum lugar e alguma mãe me falar: "Nossa, o meu filho está morrendo de saudade, ele quer te ver". Isso para mim é muito gratificante (Entrevista, 14 jun. 2014).

Dentre as várias manifestações de carinho dos(as) alunos(as) relatadas por Bianca, uma delas chama a atenção, por realçar uma característica socialmente atribuída à mulher: a maternidade:

Esse menino, que eu te falei que é homossexual, um dia eu estava em casa, no Dia das Mães, bem de manhãzinha, ele bateu palma. Eu saí lá, ele com um presente. Aí ele falou para mim - na época era tia: "Eu vim te trazer, porque você não é professora, você é minha mãe”. Eu não sei se, às vezes, ele tinha alguma dificuldade em casa, de relacionamento, e ali ele se apegou. Então, eu falo que isso aí, nossa, é muito gratificante. É muito gratificante (Entrevista, 14 jun. 2014)

De acordo com o relato dessa professora, seu carinho e seu cuidado por um aluno fizeram com que ele a associasse à figura materna. No entanto, mais do que isso, tal fala 
evidencia, assim como no caso de Gislaine, a força dos valores incorporados durante os processos de socialização em relação às diferentes formas de ser mulher, bem como a feminização das atividades docentes. Isso se dá porque "o lugar que homens e mulheres ocupam em nossa sociedade, suas imagens e atividades que desempenham refletem e constituem algumas das visões apriorísticas advindas de seu processo de socialização" (VIANNA, 1998, p. 326).

Em outras palavras, Bianca passou por processos de socialização que admitiram a maternidade como atividade estritamente vinculada à mulher. Lembremos que ela chegou, inclusive, a morar em Brasília para ajudar a irmã a cuidar do sobrinho. A combinação entre maternidade e docência ocorre, então, a partir do momento em que os processos de socialização da mulher/mãe vão ao encontro de uma atividade profissional marcadamente feminina, e isso não por uma questão quantitativa - já que o predomínio das mulheres no magistério é significativo -, mas sim pela incorporação de significados femininos a essa profissão. Como explica Marília Pinto de Carvalho (1998), é nesse âmbito que o gênero, enquanto construção social de significados, atravessa as relações sociais e instituições como o mercado, o trabalho, a escola etc.

A questão central quanto ao trabalho docente é, desse modo, que sua "feminização" não é apenas a entrada de mulheres na ocupação de professora, mas um processo de deslocamento de significados - da escola, da ocupação, do ensino, da mulher, da feminilidade, da maternidade, da masculinidade, da criança - que resultou na contiguidade observada hoje entre as representações de mulher, mãe e professora. Da mesma forma, conceitos como profissão, proletarização, qualificação e desqualificação, combatividade sindical e desmobilização estão articulados, nessa ordem, aos significados historicamente mutáveis do masculino e feminino, isto, é, à história do gênero (CARVALHO, 1998, p. 402).

Em tal cenário de atribuição de significados femininos ao magistério, a associação da mulher à docência e da professora à mãe, conforme se evidencia no rela to de Bianca, aparece como uma relação mais do que certa e natural. Logo, a "relação entre as expressões de masculinidade e da feminilidade - mesmo estereotipadas e cristalizadas - e a própria docência permite ver a feminização do espaço escolar e das atividades docentes até mesmo quando exercida por homens" (VIANNA, 1998, p. 332). 
Outro caso interessante narrado pela entrevistada refere-se à sua preocupação com uma criança que apresentava trejeitos femininos na infância e que posteriormente, na vida adulta, confirmou-se como homossexual: anos mais tarde, certa vez quando se reencontraram, o ex-aluno lhe apresentou o namorado. Embora procure agir de maneira neutra em relação às manifestações de sexualidade em sala de aula, Bianca revela que encontra dificuldades para lidar com tais situações. É justamente nesse momento da entrevista que a professora cita o comportamento das meninas que, para ela, são sexualmente mais precoces que os meninos, fato que percebe no dia a dia da escola. Segundo ela, o comportamento sexual precoce das meninas a incomoda, a ponto de ela confessar que não sabe como reagir a essa nova conduta feminina:

Olha, eu percebo assim, a cada ano eu percebo as meninas mais centradas nos meninos, eu percebo muito. Esse ano, eu percebo muito assim na minha sala. Os meninos, às vezes, reclamam: "Pro, a gente quer brincar e elas ficam aqui, elas puxam a gente" [...]. A gente tinha, assim, uma certa separação, até pouco tempo, as menininhas, você saía para recreio, você via as menininhas brincando aqui, os menininhos ali, era uma coisa. Hoje em dia, não. E eu percebo que são elas que chegam. Às vezes, eles vêm reclamando alguma coisa delas, eu vou questioná-los, eles falam: "Não, Pro, mas elas foram lá". Então, eu não sei se o mundo está evoluindo [...]. Eu percebo muito isso nas meninas, até me incomoda um pouco [...]. E a brincadeira é sempre de agarrar, de puxar, sabe? [...]. Elas são muito, muito ligadas em estar com menino, em brincar com menino (Entrevista, 14 jun. 2014).

O discurso de Bianca, assim como o de Gislaine e Celina, está carregado de valores ligados à feminilidade patriarcal (PISANO, 2004), visto que, ao ser encorpado por uma cultura machista, reforça a ideia de que a mulher deve ser recatada. Dessa forma, é assustador, para ela, que as meninas possam demonstrar algum tipo de interesse sexual em relação aos meninos, pois tal comportamento não condiz com o papel social que deveria ser representado por uma menina. Assim sendo, além de não promover a interação entre as crianças, a professora reforça, em sua fala, os papéis sociais impostos a meninas e meninos. Conforme assinala Fabiana Cristina de Souza (2006, p. 99),

[...] as crianças só são reconhecidas quando assumem papéis que estejam dentro dos padrões socialmente aceitos para seu sexo, o que nos permite adiantar que as experiências quanto as expectativas quanto 
os papéis sexuais diferenciados são reforçados constantemente desde os primeiros anos escolares.

Os relatos de Bianca sobre suas dificuldades em relação às manifestações de sexualidade em sala de aula e ao comportamento das meninas encaminharam a entrevista à sua participação no GDE. Em um primeiro momento, questionei-a sobre os motivos que a levaram a se inscrever do curso. Ela, então, comentou que o curso chamou sua atenção porque lhe ajudaria na evolução de carreira, já que conferiria pontos que se somariam para a atribuição de aulas. Em virtude disso, o GDE lhe pareceu uma opção atrativa.

Em seguida, interroguei-a sobre sua participação no decorrer do curso, a qual, segundo ela, foi marcada por obstáculos no manuseio do computador, dado que se considera leiga em tecnologia. Todavia, com entusiasmo, a professora mencionou as trocas de ideias e conhecimentos que ocorreram nos fóruns de discussão: "Então, ali surgiam tanta, sabe, tanta troca, tanto comentário legal ali do que você tinha visto, alguma posição do que você colocava, e aí surgiu muito" (Entrevista, 14 jun. 2014).

A fala de Bianca sobre o GDE pareceu-me um pouco vaga quanto às contribuições oferecidas durante a formação. Devido ao tempo transcorrido desde então, ela não mais se lembrava do projeto que havia elaborado. Contudo, seu envolvimento com o curso pôde ser notado nas tarefas realizadas na plataforma Moodle, nas quais ela já assinalava alguns dos questionamentos apresentados durante a entrevista, especialmente quanto às dificuldades do(a) educador(a) para lidar com as manifestações de sexualidade e relações de gênero na escola, bem como quanto à posição desfavorecida da mulher em uma sociedade patriarcal.

Muitas vezes é mais cômodo não pararmos para pensar e até mesmo termos atitudes diante dos preconceitos, mas eles estão presentes no nosso dia a dia e principalmente no exercício de nossas profissões (Memorial, 29 abr. 2010).

Primeiro a situação que muitas companheiras "mulheres" ainda vivem no nosso mundo e como muitas vezes nós mesmas nos colocamos na posição de submissas e quando ameaçamos uma reação paramos diante do fato de sermos "mulheres". O que o homem faz a mais do que se espera como pai, marido ou amante e porque ele é "ótimo". A mulher quando se supera em qualquer de suas atribuições (que são muitas) é o que se esperava dela (Diário, 15 abr. 2010). 
Como trabalho final do curso, Bianca elaborou o projeto intitulado Despertar, que tinha como referência o Módulo 3 (Sexualidade e Orientação Sexual) e objetivava, por meio do conhecimento do corpo, a valorização da autoestima das crianças. O projeto, porém, não chegou a ser aplicado. Segundo a entrevistada, ela à época chegou a comentar sobre o curso com a diretora de sua escola, que não levou adiante o desenvolvimento da ideia. O ocorrido a fez salientar, mais uma vez, as dificuldades para se trabalhar sexualidade e relações de gênero no ambiente escolar:

Eu acho que é meio, sei lá, tem uma espécie de tabu, de você chegar, entendeu? Porque eu lembro que, na época, você está falando do projeto, eu encontrei a diretora e ela me perguntou como é que estava indo, aí eu falei de como era, que era muito legal. Aí ela me falou: "Ah, depois a gente vai ver, Bianca, certinho. Vamos ver se a gente desenvolve alguma coisa nesse sentido" [...]. Mas não foi feito não. Eu acho que existe uma certa dificuldade de chegar, de lidar com esse tema, de conseguir essa... eu acho que é todas nós (Entrevista, 14 jun. 2014).

A entrevista de Bianca revelou uma pessoa observadora e questionadora em relação às diferentes formas de ser mulher. Além de perceber e sentir na própria pele que homens e mulheres não são iguais em direitos, fato que leva as mulheres a se desdobrarem mais para alcançar os mesmos resultados que os homens, ela também questiona tais construções sociais acerca do gênero. Essa premissa, por sua vez, ao ser corroborada durante o GDE, endossa as percepções da docente, que, em muitas passagens, mostra-se indignada com a condição da mulher no patriarcado.

Em relação ao que entende por ser professora, Bianca demonstra toda sua paixão pela docência. Embora não descarte os entraves que envolvidos na profissão docente, ela se sente inteira e realizada como professora, a ponto de confundir o eu pessoal com o eu profissional. Também é ciente de suas dificuldades no ato de lecionar, entre as quais aponta o tratamento das manifestações de sexualidade pelo(a) professor(a).

É justamente nesse sentido que o GDE surge como um prenúncio para essa docente, pois a faz enxergar a presença da sexualidade e do gênero na escola, bem como todo o preconceito em torno dessas questões. Os efeitos do curso, porém, são rasos em Bianca, visto que, além de se tratar de uma formação breve, enfatiza temas que 
esbarram em questões morais e em processos de socialização assentados em uma cultura patriarcal que reforça as desigualdades de gênero.

\subsection{Carla: "Confesso que tenho muita dificuldade em me relacionar com pessoas [diferentes]" 27}

Nascida em 1981 na cidade de Irapuã, interior de São Paulo, Carla ali reside até hoje. É casada há 11 anos e tem duas filhas: uma com 9 e a outra com 6 anos.

A entrevista ocorreu em sua casa, onde fomos interrompidas várias vezes, ora por alguma de suas filhas, ora por ela mesma chamando a atenção de seu cachorro, que latia ininterruptamente. Durante nossa conversa, Carla pareceu estar tensa e apressada para que tudo acabasse logo, respondendo de forma sucinta às questões que eu lhe fazia. Desde nosso primeiro contato por telefone, ela se manteve receosa, justificando que não se lembrava do que havia aprendido durante o curso Gênero e Diversidade na Escola e que, assim, não poderia me ajudar. Foi então que expliquei, mais de vez, que a entrevista não tinha caráter avaliativo, mas visava compreender os significados sobre ser mulher e ser professora a partir de sua participação no GDE.

Carla deu início ao seu relato contando de sua família humilde e de sua vida no sítio até os 9 anos de idade. Segundo ela, enquanto sua mãe era mais maleável, seu pai era extremamente bravo e rígido na educação dos(as) filhos(as), de modo que todos(as) da família tinham medo dele, inclusive a esposa.

Assim, tal como nos casos de Gislaine, Celina e Helena, a figura do pai também é acompanhada do medo na vida dessa docente. Novamente é possível perceber estratégias patriarcais de subordinação da mulher ao papel de mãe, esposa ou filha, conforme destaca Margarita Pisano (2004). É nesse sentido que a fala de Carla evidencia a rigidez paterna como um mecanismo de controle do comportamento feminino, produzindo medo e obediência nas mulheres:

\footnotetext{
${ }^{27}$ Entrevista realizada em 14 de junho de 2014.
} 
[...] o meu pai era bem rígido, ele era daquele um, assim, que se ele tivesse conversando, você não podia passar no meio, coisas que hoje em dia a gente, eu acho, que deixa as crianças fazerem. Mas ele era muito bravo. A gente sentava para comer, ninguém podia conversar na hora da comida, nada. Era bem... ele era muito bravo [...]. Ele era muito pulso firme. Ele chegava, mudava o comportamento de todo mundo, até a minha mãe ficava mais quieta, assim, parece que tinha medo dele (Entrevista, 14 jun. 2014).

Sobre sua infância, ela relata algo que diz ter lhe marcado muito: o fato de sempre brincar sozinha, pois, diferentemente de seus irmãos (um irmão mais velho e uma irmã mais nova), que gostavam de brincar de bola e estilingue, ela preferia as bonecas. A aproximação com a irmã mais nova se deu na adolescência, quando Carla, muito vaidosa, começou a perceber o interesse da irmã por coisas de menina. Foi exatamente esse ponto em comum, a vaidade, que as tornou companheiras:

Agora, pensando assim, desde criança eu me vejo de batom na boca, sempre maquiada, sempre bem assim, e adolescente também. Eu era muito estudiosa, e estudava aqui mesmo, cuidava da casa para a minha mãe, que ela trabalhava fora, eu e a minha irmã. E sempre estudando, pensando assim: continuar estudando, fazer faculdade, essas coisas. Mas sempre dentro, assim, de aprender a bordar, aprender a fazer essas coisas (Entrevista, 14 jun. 2014).

Pude notar que a vaidade é um ponto de destaque na personalidade dessa professora desde o primeiro momento em que a vi pessoalmente. Durante nossa conversa, ela estava maquiada e bem vestida, o que, de certa forma, confirma sua preocupação com a estética.

Em tal contexto de valorização da aparência, a vaidade também aparece na concepção de Carla sobre o que entende por ser mulher: "O que é ser mulher? Eu penso só em vaidade, que os homens já estão roubando das mulheres também, né?" (Entrevista, 14 jun. 2014). Assim, de forma semelhante a Gislaine, Carla associa a vaidade ao fato de ser mulher, ressaltando-a como um elemento diferenciador entre homens e mulheres, uma vez que se apresentaria, em sua visão, como uma característica mais feminina do que masculina.

Não há como negar que a vaidade está intimamente ligada à beleza, já que o cuidado com a aparência remete à admiração do que é belo. Consequentemente, quando 
se associa a vaidade à beleza, a figura da mulher emerge, visto que há toda uma construção social em torno da associação da beleza à mulher (WOLF, 1992).

Ao discutir a relação entre gênero e beleza, Nucia Alexandra Silva de Oliveira (2000) afirma que, apesar das constantes transformações no que tange aos padrões estéticos, a estética tem no sujeito feminino seu maior alvo mercadológico. Segundo a autora, é a partir do século XX, principalmente com a vinculação de propagandas publicitárias, que a beleza se torna um dos elementos constitutivos de sua condição de mulher.

Em um recorte histórico feito entre os anos de 1960 e 1970, Oliveira (2000) constata o funcionamento da imprensa brasileira como um dos dispositivos que mais veiculavam valores referentes à construção de gênero. Nesse âmbito, os discursos sobre a beleza e a vaidade tornam-se elementos definidores da feminilidade e da diferenciação entre homens e mulheres. Em vista disso:

A ênfase na diferença entre os gêneros, indicada aqui e pensada no que se refere à beleza, permite-nos discutir a bipolaridade masculinidade/ feminilidade por conta deste elemento chave que, acreditamos, ainda é pouco explorado. Quando afirmamos isto, estamos pensando que a beleza foi sendo articulada como um elemento de definição de gênero, quando anteriormente era pensada, sobretudo, como uma questão de classe. Não pensamos que uma questão tenha substituído a outra, mas sim que, atendendo determinadas relações, elas se intercalem, com cores e faces diferentes, inesperadas como as figuras de caleidoscópio, que dependem da perspectiva das luzes que chegam até ele (OLIVEIRA, 2000, p. 181).

Em outro artigo, Oliveira (2007) mostra que, nas décadas de 1950 e 1960, os anúncios publicitários das revistas brasileiras vendiam a ideia de que a beleza é um investimento e, portanto, poderia ser comprada. Tais discursos não deixavam de ser generificados, uma vez que atribuíam delicadeza e graciosidade à beleza feminina, ao passo que a beleza masculina encontrava respaldo na força e na virilidade.

Ainda segundo a autora, nos anos 1970 e 1980, as conquistas femininas em sociedade demarcaram o surgimento de uma nova mulher: aquela que é independente e emancipada. No entanto, embora associada a uma questão de autoestima, a beleza ainda mantém o foco no cuidado com a aparência. Assim, por mais que a abordagem da 
questão estética tenha mudado de perspectiva, sua associação ao sujeito feminino permanece uma constante. Esclarece Oliveira (2007, p. 308):

Em relação aos anos 70 e 80 , pode-se dizer que a "nova" mulher brasileira não conheceu apenas novidades. Ela também conviveu, em suas leituras, com discursos que buscavam a manutenção de certos papeis. Ela "aprendeu", por exemplo, que seu corpo precisava de cuidados e embelezamento, visto que a beleza poderia ser - além de um prazer ou um "símbolo" de sua auto-estima e liberdade - algo que a definiria ou a qualificaria como uma "mulher de verdade". Ou seja, segundo o discurso que havia sido publicizado nas décadas anteriores, a beleza apresentada às "novas" mulheres também estava associando este elemento à feminilidade. A beleza - e os elementos associados à ela, tais como a juventude e magreza - continua a ser usada para definir as mulheres como verdadeiramente femininas. Enfim, ser bela continuava sendo descrito como a melhor maneira de ser feminina.

É interessante observar como a fala de Carla reproduz tal discurso generificado da beleza e da vaidade. Em seu entendimento sobre ser mulher, ela admite que a vaidade, nos últimos tempos, vem fazendo parte do universo masculino. No entanto, sua fala apresenta uma nítida demarcação da vaidade como uma característica primeiramente da mulher e da qual os homens estariam timidamente se apropriando. É com base nessa fala que podemos observar, portanto, como se dá a construção dos significados e dos símbolos empregados na compreensão da categoria mulher a partir, por exemplo, da utilização da beleza e da vaidade como características próprias do feminino.

Embora a vaidade seja, para Carla, um elemento definidor do que entende por ser mulher, durante a entrevista também pude observar outras percepções suas em torno da figura feminina. Ao comentar sobre as manifestações de sexualidade e relações de gênero na escola, por exemplo, a professora indica sua compreensão de que ser mulher é também ser passiva e comportada:

Olha, as meninas, elas estão mais, assim, atiradas. Antigamente, as meninas esperavam os meninos partirem para a iniciativa, tinha uma paquera de olhar e depois o menino que ia atrás. Hoje, não. A menina, elas vão, elas dão em cima deles, mais do que ele. Elas não esperam, elas que estão indo atrás. A gente não sabe nem o que pensar. Outro dia, a menina lá comentando que ela tinha ficado com dois meninos e uma menina. Então, você não sabe: Gosta de menino ou gosta de menina? Eu não sei o que pensar [...]. Então, como se diz, eu ouço e 
fico quieta, eu não falo nada para elas, não aconselho (Entrevista, 14 jun. 2014).

A feminilidade patriarcal (PISANO, 2004) está presente no discurso de Carla, do mesmo modo como se encontra nos depoimentos de Gislaine, Celina e Bianca. Estando imersas na cultura masculina, essas professoras reproduzem os ditados patriarcais, o que as leva a projetar como aceitável - embora algumas delas fujam dessa representação - somente uma forma de ser mulher: a passiva, a cordata.

No caso de Carla, essa não aceitação de outras formas de ser mulher fica evidente quando ela afirma preferir o silêncio em vez de se posicionar diante de situações que lhe causam certo estranhamento, como no caso das alunas que tomam a iniciativa em um relacionamento ou, então, namoram tanto com meninos quanto com meninas. A não aceitação do diferente também se torna evidente em sua participação na plataforma Moodle durante o curso: "Confesso que tenho muita dificuldade em me relacionar com pessoas (diferentes) e principalmente como professora tenho necessidade de aprender a lidar com isso" (Diário, 17 abr. 2010).

O silêncio e a falta de posicionamento de Carla diante daquilo que reprova não se referem apenas à temática do comportamento feminino. Nesse sentido, também foi possível perceber sua não aceitação da homossexualidade, quando ela se reportou à presença de um professor homossexual no corpo docente de sua escola. Segundo ela, as professoras, sobretudo as mais velhas, não gostam da forma como esse professor se porta e reclamam de seu comportamento, julgando-o inadequado ao ambiente escolar. Carla, por sua vez, permanece em seu silêncio:

[...] esse professor, assim, se tiver uma brechinha na hora do intervalo, na troca de periodo, que ele tiver que contar alguma coisa, ele fala abertamente, escancaradamente. E aí tem umas professoras que já reclamaram que não gostam do jeito dele, do jeito dele falar, porque ele fala assim, aberto, ele fala com quem ele saiu, com quem ele não saiu, se a pessoa é casada, se a pessoa não é, ele conta, ele fala abertamente. Que nem, eu ouço, nem incentivo ele a falar, e fico na minha. Mas tem umas professoras mais velhas, assim, que elas não gostam, e elas reclamam quando ele fala alguma coisa, acham que não é o lugar, que o que ele faz é dele, então, ele que guarde para ele, que ele não fale ali no meio (Entrevista, 14 jun. 2014). 
Tal como observamos no relato de Celina, Carla evidencia uma concepção que entende a sexualidade como algo privado e reservado. A percepção do sexo como um tema íntimo, pessoal e carregado de preceitos morais revela, de certa forma, um pouco da personalidade e do comportamento dessa professora ao longo da entrevista. Em outras palavras, entendo que a reserva e a desconfiança de Carla desde o nosso primeiro contato estão ligadas à vergonha em falar de si, principalmente sobre um tema (a sexualidade) que, em sua compreensão, é de âmbito particular. Esse desconforto já se fazia evidente em suas participações na plataforma Moodle: "Estou muito insegura em começar a escrever estas linhas, nunca tive um diário quando adolescente e tenho grande dificuldade em me expressar. Mas, temos que escrever, então vamos lá" (Diário, 17 abr. 2014).

A esse respeito, é necessário destacar que, diferentemente das outras professoras que dizem possuir alguma religião, mas não a praticam, Carla afirma ser praticante da doutrina católica, frequentando a missa todos os finais de semana e em datas importantes. Embora ela diga que "não sou, vamos dizer assim, fanática em ir em tudo que tem na igreja" (Entrevista, 14 jun. 2014), os valores religiosos estão presentes nos processos de socialização dessa professora. Ou seja, o fato de fazer parte de uma religião que concebe o desejo sexual como pecado e a mulher como alguém que deve ser subalterna ao homem (haja vista as cartas do apóstolo Paulo) está associado a uma perspectiva privada da sexualidade e à aceitação, sem questionamentos, do comportamento passivo e contido da mulher, ideias que, por sua vez, estão presentes nos discursos de Carla.

Pode-se dizer que foi no âmbito dos princípios religiosos que Carla cresceu. Ao comentar sobre sua adolescência, ela afirma ter sido um período "banho-maria, assim, sem altos e baixos, vamos dizer" (Entrevista, 14 jun. 2014). Ademais, o comportamento contido e o medo de aparentar ser diferente são constantes no discurso dessa professora: "Eu sempre tive bom relacionamento, assim, na escola, com todo mundo. Nunca fui aquela de chamar a atenção, porque geralmente quem chama a atenção, ou por bem, ou por mal, é mais, assim, discriminado" (Entrevista, 14 jun. 2014).

Ainda sobre sua juventude, ela comentou ter tido dois namorados, sendo o último seu atual marido, com quem namorou por sete anos e se casou em seguida. A 
primeira filha do casal veio depois de um ano e meio e a segunda após três anos e meio de casamento.

Sobre ser mãe, a professora lembrou que se sentiu insegura e despreparada no nascimento da primeira filha, motivo pelo qual foi preciso que sua mãe cuidasse do bebê durante meses. Já no nascimento da segunda filha, Carla diz ter experimentado de fato a experiência de ser mãe, uma vez que "eu que fiz tudo, eu que cuidei desde a primeira fralda. Aí eu fui mãe de verdade” (Entrevista, 14 jun. 2014).

O discurso de Carla sobre a maternar, além de realçar mais uma vez sua feminilidade patriarcal (PISANO, 2004), reforça também a aceitação de um dos cativeiros destinados às mulheres (RÍOS, 2005), isto é, a maternidade. O fato de não ter participado dos cuidados com a primeira filha logo após o nascimento gera culpa na professora, a ponto de ela não se sentir verdadeiramente mãe naquele momento. Aí se evidencia, portanto, que a força dos cativeiros não está só na privação da liberdade feminina, mas, sobretudo, na incorporação de sua lógica.

Em relação à sua carreira profissional, a docente leciona a disciplina de Matemática para o Ensino Fundamental II e para o Ensino Médio há 10 anos, desde que se efetivou pelo Estado de São Paulo, em 2005. Sua formação conta com duas graduações, em Matemática e em Pedagogia, e com pós-graduação (lato sensu) em Modelagem Matemática, todos os cursos realizados em instituições particulares.

Como nos casos de Celina e Bianca, o magistério não foi a primeira opção profissional de Carla. Na verdade, ela antes iniciou o curso de Ciências da Computação, com o qual, entretanto, não se identificou. Ao perceber que as únicas aulas que lhe agradavam eram as de matemática, decidiu mudar de curso e fazer uma licenciatura na área:

No primeiro momento, não foi a primeira opção. Mas deu certo de eu transferir e me identifiquei fazendo Matemática [...]. Eu gostava de matemática, mas eu gostava, assim, de explicar para os outros, gostava de saber para explicar [...]. Agora eu lembrei, quando eu estudava no ensino básico, a professora de matemática saía da sala e deixava eu corrigindo. E aí, às vezes, eu explicava, eu adorava brincar de professora (Entrevista, 14 jun. 2014). 
O gosto por ensinar aparece em outros momentos durante a entrevista, por exemplo, quando Carla, ao destacar que é vaidosa e feminina desde criança, menciona o brincar de escolinha como uma de suas brincadeiras preferidas: "sempre fui do lado, assim, bem de menina mesmo, de brincar com boneca. Eu nunca gostei de chutar bola, de subir em árvore. Bem assim: brincar de escolinha. Então eu dava aula para as minhas bonecas, bem essas coisas (Entrevista, 14 jun. 2014).

Seu relato evidencia a associação de características femininas à docência, visto que, em suas lembranças, o brincar de escolinha é enquadrado em um conjunto de brincadeiras de meninas. É nessa lógica que os processos de socialização referentes à construção das diferentes formas de ser mulher nos ajudam a compreender sua opção pelo magistério. Conforme explica Cláudia Vianna (1998, p. 326), "quando a maioria das professoras (e não dos professores) afirma que gosta de dar aulas desde crianças, ganha relevo o peso desse processo, das concepções nele adquiridas e que embasam o prazer pelo magistério".

A partir dessa fala, questiono Carla sobre o que é ser professora. Segundo ela, o magistério a realiza, tanto que ela não consegue ver-se em outro emprego. Embora ela destaque a desvalorização da carreira docente, tal como faz Celina, dar aulas é o que lhe traz satisfação profissional.

Lógico, eu queria que a gente fosse melhor aceito pelos alunos. Mas, para mim, é tudo. Eu me sinto realizada, principalmente quando eu consigo planejar uma aula, ir lá e executar ela. Não venho embora remoendo que não deu para fazer o que eu queria porque, às vezes, agora está assim para dar uma aula, está difícil de você concluir o que você planeja (Entrevista, 14 jun. 2014).

De forma semelhante a Helena, Carla destaca o(a) professor(a) como alguém importante na construção de conhecimento do(a) aluno(a). Todavia, diferentemente de Helena, essa professora parece não se envolver em questões que estejam além do ensino de matemática:

Para mim, ser professora é ajudar o aluno a construir o conhecimento dele, pegar o que ele já tem e encaminhar ele, ajudar ele a chegar no que ele tem que aprender, não é no que eu quero, é no que ele tem que aprender [...]. No meu caso, seria ele aprender a matemática que ele 
precisa para prestar um vestibular, para prestar um concurso, alguma coisa nesse sentido (Entrevista, 14 jun. 2014).

Isso se torna mais perceptível quando pergunto a ela sobre sua participação no GDE. Assim como Gislaine e Bianca, Carla explica que fazer o curso the ajudaria em sua evolução funcional, tendo em vista que se tratava de um certificado de 200 horas. Apesar disso, ela afirma ter se envolvido com o curso.

Nas atividades realizadas na plataforma Moodle, é perceptível sua indignação perante o material Escritos Milenares, bem como o realce que ela dá à figura do(a) professor(a) na construção de uma educação para a diversidade:

A indignação toma conta de qualquer "mulher" ao ler os "Escritos Milenares". É difícil não se imaginar vivendo numa situação dessas, por isso que é revoltante (Módulo 2, Gênero, 27 fev. 2010).

Nossa responsabilidade como educadores é enorme, pois devemos assumir conscientemente nosso papel de educadores, garantindo às crianças uma formação com maior autonomia para construirmos uma sociedade onde os adolescentes vivenciem sua sexualidade com prazer e responsabilidade, assim teremos adultos mais satisfeitos e menos presos em concepções conservadoras e limitadas (Módulo 3, Sexualidade e Orientação Sexual, 18 mar. 2010).

Ela também afirma que participar do curso lhe abriu um leque de conhecimentos sobre sexualidade e relações de gênero, mas destaca que seria complicado colocar em prática, nas aulas de matemática, aquilo que aprendeu. Em virtude disso, o projeto Despertar, elaborado juntamente com Bianca, não foi aplicado por Carla em sua escola:

\begin{abstract}
Abriu um leque para mim sobre muitos assuntos, só que eu não sei se a gente coloca em prática. Eu acho que é essa a falta, eu acho que faltou o projeto ser colocado em prática. Nem tudo o que a gente ouve ou que a gente aprende... no momento que a gente vê, você até gosta do que você está vendo. Você fala: "Ó, isso é bacana, e tal". Mas ai eu acho que falta colocar em prática, e aí eu acho que vai caindo no esquecimento [...]. Para eu colocar um projeto desse ia dar trabalho, porque, se fosse um professor de ciências, biologia, assim, eu acho que seria mais fácil. Dentro da matemática, lançar um projeto desse seria complicado (Entrevista, 14 jun. 2014).
\end{abstract}

Ao delegar ao(à) professor(a) de ciências ou biologia a tarefa de trabalhar as questões sexuais e de gênero na escola, Carla acaba reduzindo a sexualidade a um 
caráter estritamente biológico, o que corrompe qualquer possiblidade de desconstrução de estereótipos, preconceitos e desigualdades de gênero. Ademais, para essa professora, falar de tais temáticas na escola pode gerar incentivos à prática sexual. Essa ideia se evidencia quando ela relata a visita de uma profissional da saúde na escola em que leciona:

Eu acho que, dependendo do jeito que for colocado, assim, eles podem achar que está incentivando, ser um incentivo [...]. Um tempinho atrás, teve lá as enfermeiras falando sobre gravidez, isso e aquilo, e ensinando o método contraceptivo. Aí você ouve... Tinha uma moça lá, uma moça não, uma senhora da limpeza, que falou, assim, que "Elas estão ensinando", como se tivesse incentivando as meninas a fazer relação. Elas estão ensinando a se cuidar, não mandando fazer relação. Mas, a pessoa olha com esse olhar que ela quer olhar, que ela está incentivando, a enfermeira foi lá incentivar as meninas a usar camisinha. Mas ela não fala do lado que elas vão pegar doença ou ter uma gravidez. Eu acho que é levado para o outro lado, não para o lado bom, é para o lado ruim, eu acho (Entrevista, 14 jun. 2014).

É interessante notar como a fala de Carla sobre esse episódio pode nos fornecer algumas interpretações acerca de suas concepções sobre sexualidade e relações de gênero: primeiro, a prática do sexo é mais perigosa do que prazerosa; segundo, pode resultar em doenças sexualmente transmissíveis (DSTs) e em uma gravidez indesejada; terceiro, a procriação aparece somente como uma consequência da prática sexual, e não como um direito de escolha; quarto, todo o discurso dessa professora dirige-se às meninas ("que elas vão pegar doença ou ter uma gravidez"), sugerindo, portanto, que cabe às mulheres o cuidado referente à prática sexual.

A elaboração do perfil de Carla evidenciou que ela pouco questiona os cativeiros que lhe são impostos pela sociedade patriarcal. Devido a isso, não se sentiu sensibilizada ou motivada para colocar em prática o conhecimento com que teve contato durante o curso Gênero e Diversidade na Escola.

Ressalto que o propósito, aqui, não é criticar a participação de Carla no GDE. A referida professora parte de um processo de socialização com intensas influências religiosas, bem como de uma formação docente (como as outras professoras entrevistadas) que provavelmente não lhe deu respaldo para um tratamento crítico e menos preconceituoso a respeito das diversidades sexuais e de gênero. Assim, por mais 
que ela esteja ciente da presença da diversidade em seu cotidiano e na escola, demonstra dificuldades em tolerá-la.

Os relatos de Carla revelam, portanto, a força dos processos de socialização, evidenciando entraves para a efetivação de uma política pública que tenha em vista a desconstrução de estereótipos e preconceitos em torno das orientações sexuais e das identidades de gênero.

\subsection{Maria Rita: “Você quer ter um filho homossexual? Se a pessoa falar 'quero', é mentira." 28}

Maria Rita nasceu em 1967 em Riolândia, cidade pequena do interior de São Paulo, mas há 17 reside em São José do Rio Preto. Aos 48 anos à época da entrevista, ela tem dois filhos já adultos - uma menina e um menino - e é casada há 31 anos.

A entrevista ocorreu na escola em que ela hoje é diretora, mais especificamente no almoxarifado da instituição, local onde, segundo ela, ninguém nos interromperia. Espontânea e de muito bom humor, Maria Rita conversou comigo como se nos conhecêssemos há tempos. Explicou-me detalhadamente tudo o que lhe perguntei e defendeu seus pontos de vista com muita convicção.

Foi falando sobre sua família que nossa conversa teve início. Filha de pais que completaram apenas o ensino fundamental, Maria Rita relata ter tido uma infância simples, porém muito feliz. Lembrou-se, por exemplo, de que brincava na rua, subia em árvores e tinha muitos(as) amigos(as). Além disso, segundo ela, sempre gostou de sair, ir a festas e dançar.

Mas sempre gostou também de estudar, motivo pelo qual se descreve como uma pessoa questionadora e com muito interesse em aprender, o que fazia dela uma aluna exemplar. É uma leitora voraz desde que aprendeu a ler, tendo anteriormente que encomendar livros via catálogos, uma vez que não havia livrarias em Riolândia.

\footnotetext{
${ }^{28}$ Entrevista realizada em 16 de junho de 2014.
} 
É a única filha mulher, entre quatro irmão homens e um pai ciumento e conservador. Pelo fato de ser menina, relata que o controle paterno foi exercido de maneira severa sobre sua vida, sobretudo no período da adolescência. Relembra, por exemplo, certa vez em que estava ansiosa para ir a um baile Country de sua cidade e que se produziu lindamente para a festa, mas permaneceu pouco tempo no local, pois seu pai foi lhe buscar cedo demais. Segundo ela:

Aí, quando chegou no baile, o baile começava às 11h00. Meia-noite o meu pai me levou embora, a hora que o baile estava começando. Eu quase morri de tanto chorar. Chorei a noite inteira ao lembrar desse baile, e eu não podia ficar (Entrevista, 16 jun. 2014).

De todas as professoras entrevistadas, certamente Maria Rita apresenta o relato em que o controle paterno foi mais marcante. Ela fala do pai com certa mágoa, visto que suas proibições lhe causaram muito sofrimento: "Então, essas coisas, assim, que ele me tolhia, que ele não deixava eu viver, isso aí marcou bastante" (Entrevista, 16 jun. 2014).

Embora a professora aí se refira a um período de sua vida em que era filha, é possível dizer que, já naquele momento, o cativeiro referente ao papel de mãe e esposa se fazia presente. Isso se dá pois, como afirma Marcela Lagarde y de los Ríos (2005, p. 370), "cuando no son progenitoras (no tienen hijos) ni esposas (no tienen cónyuege), las mujeres son concebidas y son madresposas de maneras alternativas”. Nesse sentido, Maria Rita começou a sentir o peso do patriarcado já na figura de seu pai.

Foi devido a tal controle que Maria Rita se casou cedo: começou a namorar escondido aos 14 anos, ficou noiva aos 15 e aos 17 se casou. Todavia, o casamento não lhe foi um cativeiro, mas sim uma libertação em relação aos imperativos paternos: com muito entusiasmo, ela relata a parceria que tem com o marido, que, segundo ela, foi e é muito companheiro, participa da criação dos filhos, dá apoio em sua profissão e, como ela, adora sair e dançar.

Tendo sido mãe aos 19 anos, ela afirma que a maternidade não lhe tirou a vontade de se divertir. Todavia, enfatizou que tanto ela quanto o marido nunca se isentaram da responsabilidade envolvida na criação dos filhos: 
Era assim: se precisava de ir num baile (eu queria ir no baile, eu sempre gostei, sempre fui festeira, gostava de baile), eu levava ela bebê, deixava ela na casa de uma amiga que também tinha bebê, com a mãe dela. Aí, quando eu percebia que o seio estava enchendo muito de leite, na madrugada, eu ia lá dar de mamar e voltava de novo para dançar. Quando amanhecia o dia, buscava o bebê, enrolava todo num cobertorzinho, e eu e meu marido íamos embora para casa [...]. Porque eu fui mãe com 19 anos, muito menina, mas nunca sem responsabilidade, sempre com muito cuidado (Entrevista, 16 jun. 2014).

É a partir desses relatos que questiono essa professora sobre o sentido de ser mulher. Para responder à questão, Maria Rita relembra seu passado, destacando, mais uma vez, o sofrimento provocado pelo cativeiro mãe-esposa que seu pai lhe impunha:

Ai, meu Deus, tem tantas vertentes no ser mulher. Eu sempre brinco, eu falo que, na outra vida, quando eu vier, eu quero ser homem. Porque homem tem uma vida, assim... Se eu comparar com a vida que os meus irmãos sempre levaram e com a vida que eu sempre levei, ser homem é melhor, porque eles podiam sair a hora que eles quisessem, eles podiam voltar a hora que eles quisessem, podiam namorar o tanto que eles quisessem, que não tinha nenhum problema. E na criação que eu tive, tudo para a mulher não podia, era errado, a mulher ia sujar o nome, era feio, não podia, então eu sempre fui muito castrada. Mas, hoje, depois que eu me libertei, que eu saí de casa, que eu me casei, aí a minha vida se transformou, sou outra pessoa. Hoje, eu amo muito ser mulher. Eu acho que mulher é frágil, ela é forte, ela é mãe, ela é batalhadora, a mulher sabe sentir mais dor que homem, a mulher é mais guerreira, a mulher é mais bonita, a mulher se cuida mais, e a mulher é muito mais dedicada ao trabalho do que o homem (Entrevista, 16 jun. 2014).

Assim como Helena e Bianca, essa professora consegue perceber o peso existente em torno da figura feminina. Isso porque, ao comparar sua vida à de seus irmãos, ela evidencia o quanto teve que resistir para se libertar das amarras do patriarcado. Devido ao período intenso de resistência ao poder advindo dos processos de socialização referentes à sua formação como mulher-esposa, a fala de Maria Rita revela que, até determinado momento, ela não gostava de ser mulher", o que irá se modificar somente após sua libertação: quando ela deixa de ser filha e se torna esposa.

De certa forma, toda a resistência engendrada por Maria Rita é uma maneira de refutar o feminino patriarcal (PISANO, 2004), visto que, em vez de se entregar à representação de mãe-esposa, naquela fase inicial de sua vida, ela nega a permanência 
em uma posição de subordinação: "eu fui a única filha que deu conta de sair da barra da saia do meu pai, sair, trabalhar, estudar e se libertar. Os meus irmãos, até hoje, todos moram em volta da casa do meu pai" (Entrevista, 16 jun. 2014). Por conseguinte, por mais que tenha optado pelo casamento para se livrar do controle paterno, ela desconstrói o essencialismo feminino, pois, ao manter uma postura de enfrentamento, ela questiona e, ao mesmo tempo, cria estratégias para se libertar do poder que emana da supremacia masculina. Logo, ao refutar a feminilidade patriarcal, Maria Rita refuta também a masculinidade triunfante, ou, como explica Margarita Pisano (2004, p. 7):

No lograremos desmontar la cultura masculinista, sin desmontar la feminidad. La construcción y localización que han hecho de nosotras como género no es neutra, la masculinidade necesita colaboradoras, mujeres/femeninas, funcionales a su cultura, sujetos secundarizados que focalicen su energía y creatividad en función de la masculinidad y sus ideas.

Nesse sentido, penso que sua definição sobre ser mulher, de certa forma, é uma descrição dela própria. Ou seja, por mais que ela mencione a fragilidade, a maternidade e a beleza para definir o feminino, ela não deixa de destacar a força, a batalha, a resistência e o espírito guerreiro em torno do que compreende por ser mulher, palavras que, por sua vez, estão presentes na constituição de sua história de vida. É preciso destacar, portanto, a importância de se reconhecer o essencialismo envolvido na construção da mulher como um dos caminhos para a libertação.

Contudo, a recusa ao feminino patriarcal não se mantém na Maria Rita professora. Sua história na docência inicia-se com o ingresso no magistério, época em que já estava casada e sua filha ainda era bebê. Fez depois a graduação em Pedagogia e a pós-graduação (lato sensu) em Psicopedagogia, ambas em instituições particulares. Tornou-se efetiva pela Prefeitura de São José do Rio Preto em 1998, e desde então totaliza 25 anos de trabalho na área, sendo 20 deles em sala de aula e 5 como diretora de escola.

O magistério não foi a primeira opção profissional dessa professora. Seu sonho era ser bancária, mas o fato de haver um curso de magistério em sua cidade lhe facilitou o ingresso: 
No começo, no começo, quando eu morava em Riolândia, lá não tinha opção, não tem faculdade. Para estudar teria que ir em Votuporanga. O meu pai não deixava eu ir e eu precisava ter uma profissão. Então, no primeiro momento, realmente, eu fiz magistério por falta de opção, não tinha opção e eu precisava ser alguma coisa na vida, então que fosse professora. [...] $\mathrm{O}$ meu sonho de criança, eu achava lindo ser bancária, sabe? Tendo mesa, que você chegava limpinha, chegava perfumada e ia embora perfumada. E o professor, não, professor descabela, professor se suja de giz, o professor fica rouco. Então, eu sempre tive aquela visão, que ser bancária era lindo, porque lá, em Riolândia, a cidade pequenininha, um bancário era profissão de renome, ganhava super bem (Entrevista, 16 jun. 2014).

Maria Rita, entretanto, identificou-se com a docência. Em seu relato, foi perceptível a paixão com que ela fala sobre a atividade de lecionar:

Só que, quando eu adentrei a carreira de magistério, que eu comecei a dar aula, eu nunca consegui me imaginar em outra coisa, entendeu? Se eu tivesse que escolher uma outra profissão, eu não saberia o que fazer, porque eu gostei muito de dar aula. Eu fiquei 20 anos em sala de aula, eu me considero, me considerei uma professora exemplar. Nenhuma mãe nunca reclamou de mim, aliás, muito pelo contrário, elas brigavam no portão para a diretora colocar os filhos comigo [...]. Aí, quando eu comecei a dar aula mesmo, que eu vi que era uma profissão maravilhosa, e que eu nunca pensei em mudar (Entrevista, 16 jun. 2014).

É nesse sentido que, para ela, ser professora consiste em doar e dedicar-se ao magistério, oferecer o melhor, mesmo que para isso seja preciso sacrificar-se:

O que é ser professora? É dedicação, é doação, é, muitas vezes, você renunciar até à sua própria família pelos alunos. O professor que é dedicado está ali por amor à causa, mesmo porque eu me lembro que, quantas vezes, estava chegando pertinho do final do mês para pagamento, eu falava assim: "Nossa, gente, eu estou tão sem dinheiro, até esqueci que o pagamento está entrando amanhã". Eu sabia que eu estava sem dinheiro o mês inteiro, mas eu não ficava contabilizando quantos dias faltavam para o pagamento, porque é uma coisa, assim, que você não trabalha só por beleza, você trabalha porque você precisa do dinheiro. Mas eu não ficava com aquilo na cabeça, eu me doava mesmo em sala de aula. Quantas vezes eu não deixei filho doente e fui trabalhar, sempre por causa do filho do outro. Você está entendendo? (Entrevista, 16 jun. 2014).

É interessante observar que, ao destacar a doação e a dedicação ao magistério como características de um(a) bom(a) professor(a), Maria Rita acaba por revelar 
algumas marcas socialmente atribuídas às mulheres que desempenham o papel de mãe em nossa cultura. A desvalorização docente, aqui simbolizada como falta de dinheiro indicando também que, no magistério, os salários são precários -, fica, portanto, em segundo plano diante da paixão, representada pela doação e pela dedicação.

Assim, é possível notar a interferência das relações de gênero na construção do gosto de Maria Rita pela docência, uma vez que ela ressalta características socialmente femininas quando se refere à sua identificação com a docência. Tal fala, ademais, parece apontar certa contradição: como mulher, ela nega a feminilidade patriarcal, ao afirmar uma postura de resistência e enfrentamento ao controle paterno; como professora, porém, ela aceita essa feminilidade quando reforça alguns estereótipos de gênero vinculados à docência.

A contradição, na verdade, revela o caráter reprodutivo e criativo dos processos de socialização, dos quais a sexualidade e as relações de gênero fazem parte. Em outras palavras, como explica Tamara Grigorowitschs (2008), os processos de socialização não são lineares e fechados, mas sim móveis, dinâmicos e abertos, o que, de certo modo, justifica o contraste presente na postura de Maria Rita como mulher e como professora. Consequentemente, é por conta disso que ocorrem tensões ativas na relação entre indivíduo e sociedade, já que

[...] os efeitos de certas condições sociais de socialização não são determinados e previsíveis (isto é, estão sob o regime da contingência), e o que importa é como as diferentes condições de socialização possibilitam ou limitam as chances de desenvolvimento da identidade (GRIGOROWITSCHS, 2008, p. 39).

A partir de seu relato sobre doação e dedicação ao magistério, questionei Maria Rita se, em algum momento de sua carreira docente, ela já havia se deparado com manifestações de sexualidade e relações de gênero na sala de aula. Ela discorreu, então, sobre a precocidade sexual das crianças atualmente, frisando o comportamento das meninas:

Ah, as crianças hoje estão muito precoces. Nesse último ano que eu fiquei professora na $4^{a}$ série, eu me lembro que o meu filho ia lá na escola e as meninas ficavam enlouquecidas, alvoroçadas [...]. E marcava até encontrozinho, assim, com os outros menininhos mesmo de sala. Eu pegava até recadinho, bilhetinho, marcando encontro para 
encontrar na quadra na hora do recreio. Então, as meninas estão muito precoces hoje (Entrevista, 16 jun. 2014).

Como podemos ver, tal como Bianca e Carla, Maria Rita também se espanta com o comportamento das meninas em relação à sexualidade. Nesse aspecto do seu discurso, a feminilidade patriarcal faz-se novamente presente, pois reforça a ideia de que a passividade feminina é uma característica adequada à conduta de uma menina.

Além desse fato, Maria Rita cita outro momento que lhe foi marcante, destacando a dificuldade do(a) professor(a) para lidar com as questões sexuais e de gênero na escola:

Então, eu tinha um aluninho e ele tinha um jeito muito, muito afeminado. E as crianças, assim, percebiam [...]. E a mãe um dia me procurou. Eles estavam com um problema seríssimo, porque o pai tinha percebido esse jeito do menino e o pai não aceitava, o pai não aceitava o jeito do filho ser. E eu lembro que, uma coisa que me marcou muito, o pai queria saber de mim se eu achava que o menino era ou não. Então, é uma coisa muito difícil. O professor não pode fazer isso. Para começar, eu não tenho nem como dizer se a pessoa é ou não é, e o quê que é ser ou não ser, que diferença faz isso? A única coisa que eu falei para ele é que, se o filho dele tinha uma tendência mais feminina ou não, o tempo ia dizer e ele procurasse um psicólogo, um especialista, para conversar melhor com ele. Mas, se ele fosse menina ou menino, ia mudar o amor dele pela criança? O filho não ia continuar sendo dele da mesma forma? Você entendeu? (Entrevista, 16 jun. 2014).

A saia justa a que foi exposta essa docente sinaliza dois aspectos: primeiro, a falta de preparo do(a) professor(a) para lidar com a temática da diversidade sexual, visto que Maria Rita indica um especialista (no caso, um psicólogo) para resolver o conflito que uma suposta orientação sexual (digo suposta por não haver nenhuma certeza naquela circunstância, tratando-se de uma criança) estava causando entre pai e filho; segundo, o final do relato evidencia uma percepção menos preconceituosa da homossexualidade por parte dessa professora, afinal, para ela, independentemente da orientação sexual do garoto, o amor do pai pelo filho deveria continuar. Essa perspectiva, porém, não se mantém quando conversamos sobre sua participação no curso Gênero e Diversidade na Escola. 
Assim como outras entrevistadas, Maria Rita participou do GDE por uma questão de pontuação na carreira docente, o que lhe conferiria vantagem na atribuição de aulas nas escolas da Prefeitura de São José do Rio Preto. Todavia, ela afirma ter gostado do curso e se envolvido com os temas, relatando uma aprendizagem tranquila, principalmente por ser a distância. Com seu perfil de aluna autônoma e reflexiva, segundo ela, não teve dificuldades para fazer as atividades sem a presença de um(a) professor(a).

Sua participação no GDE foi marcada por um sentimento muito valorizado por ela: a sinceridade. Tanto em suas atividades na plataforma Moodle, quanto durante a entrevista, pude notar que ela prioriza dizer aquilo que pensa e sente, como uma forma de mostrar que está sendo verdadeira. Quando a questionei sobre seu envolvimento e sua aprendizagem no curso, ela disse ter percebido o quanto ele mexe com os valores das pessoas, a ponto de, muitas vezes, elas não falarem aquilo que realmente pensam:

Nos fóruns, muitas vezes, você conhece a pessoa. Você sabe muito bem como a pessoa é, porque a pessoa é da mesma cidade que você, às vezes até da mesma escola. Você sabe que a pessoa não pensa daquele jeito e, por medo de se expor, ela coloca uma outra resposta no fórum. Você está entendendo? Então é um curso, assim, interessante por isso, porque você aprende realmente a olhar, e fala: "Poxa vida, a pessoa fala que ela não tem, não tem preconceito, e ela está mentindo, é uma máscara" (Entrevista, 16 jun. 2014).

Postura semelhante pode ser visualizada em sua participação no fórum do Módulo 2, sobre gênero, quando Maria Rita fala da falsa aceitação da homossexualidade pelas pessoas e admite que não gostaria de ter um(a) filho(a) homossexual. Essa fala foi caracterizada como corajosa por uma das cursistas:

Para mim um dos assuntos mais difíceis de ser tratado é esse sobre comportamentos homofóbicos. Como algumas colegas que já colocaram sua opinião sobre essa questão, penso que aceitar ou não a diversidade sexual, depende muito da formação pessoal e religiosa que cada um ganhou durante a vida. Penso também que a grande maioria da sociedade camufla uma "falsa aceitação" O que quero dizer com tudo isso? Que na minha opinião e visão de mundo, devemos respeitar o outro em qualquer condição em que ele se encontre, cada um com sua preferência sexual. Mas, devemos ser honestos com nós mesmos e assumirmos que é difícil aceitarmos com naturalidade comportamentos diferentes daqueles ao qual fomos criados. Me perdoem àqueles que não concordam com a minha opinião, só queria 
ser honesta com os colegas e, principalmente, comigo mesma. Tenho muitos amigos que são homossexuais, respeito muito cada um deles. Mas, se perguntassem se eu queria ter um filho que não fosse heterossexual estaria mentindo, continuaria amando-o da mesma forma, mas sei que seria muito difícil aceitar sua condição. Espero que tentem entender e aceitar a minha opinião sem discriminá-la, senão estaríamos entrando em contradição com o fórum proposto. Abraços a todos! (Fórum, Módulo 2, 27 fev. 2010).

Da mesma forma, em seu memorial, ela admite sua dificuldade para desconstruir o preconceito em relação à diversidade sexual:

[...] tenho lido muito sobre o assunto, homossexualismo, e procurado mudar minha visão sobre esse assunto. Mas, viemos de uma educação historicamente discriminatória, e para me ajudar mais ainda, fui educada dentro do seio familiar para acreditar que o certo é a heterossexualidade. Como disse, esse preconceito que ainda existe em mim, nada interfere nas minhas amizades ou na minha profissão, pois tenho amigos que são homossexuais e me dou muito bem com eles. Já tive alunos também com esse gênero sexual e sempre trabalhei com os alunos a importância da aceitação do outro. Fico pensando: "porque será que as pessoas dizem que não têm preconceito, mas ninguém quer ter um filho homossexual"? É esse o meu questionamento para aqueles que camuflam o que sentem e o que pensam. Sei também que damos "a cara à tapa", quando nos expomos da maneira como estou fazendo, mas não consigo ser diferente, falo o que penso e o que sinto. Mas, sei da importância de melhorar nosso pensamento a respeito do preconceito, seja ele como for, para podermos, no futuro, ter uma cultura diferente daquela que tivemos (Memorial, 18 abr. 2010).

Embora admita que sua percepção é preconceituosa, Maria Rita demonstra partir do entendimento de que a homossexualidade é uma orientação sexual que não condiz com a verdade aprendida durante toda sua vida. Ela justifica sua não aceitação afirmando que ser homossexual pode causar sofrimento e injustiça à pessoa, visto que não está no rol das práticas e dos desejos sexuais considerados normais e aceitos pela sociedade:

Você quer ter um filho homossexual? Se a pessoa falar "quero", é mentira. Ninguém quer. Por quê? Porque a sociedade é discriminatória, a criança vai sofrer injustiça, a criança vai sofrer preconceito, e a gente, querendo ou não, foi criado numa cultura onde você sempre viu a mulher e o homem se casando. Aí você sente vergonha (Entrevista, 16 jun. 2014). 
Apesar de ela não se considerar uma pessoa religiosa, afirmando não se identificar com a doutrina católica, religião em que foi batizada e crismada, a compreensão de Maria Rita a respeito da homossexualidade recai na tradição cristã, que a vê como pecado (o que não é certo), e na sexologia, que a concebe como uma anomalia do ser humano (defeito).

Tal perspectiva religiosa e, sobretudo, médica é discutida por Jeffrey Weeks (2000), autor que analisa a produção discursiva sobre o tema a partir dos avanços da sexologia no século XIX. Segundo ele, os discursos médicos sobre a homossexualidade tinham por objetivo regular e controlar uma natureza sexual distinta, também conhecida como perversidade sexual. Em virtude disso, Weeks (2000, p. 68) afirma:

A homossexualidade tornou-se uma categoria científica e sociológica, classificando a perversidade sexual de um novo modo, e isso teve, inevitavelmente, desde então, seus efeitos na prática médica e legal, construindo a ideia de uma natureza distintiva e, talvez, de uma natureza exclusivamente homossexual.

Essa concepção de homossexualidade traz implícita a visão essencialista da sexualidade, já que se ancora na biologia para explicar e fundamentar a naturalidade da prática heterossexual. Consequentemente, refuta-se qualquer possiblidade de mudança na configuração dos desejos e prazeres sexuais, dado que:

Através de estratégias e táticas aparentes ou sutis reafirma-se o princípio de que os seres humanos nascem como macho ou fêmea e que seu sexo - definido sem hesitação em uma destas duas categorias vai indicar um de dois gêneros possíveis - masculino ou feminino - e conduzirá a uma única forma normal de desejo, que é o desejo pelo sujeito de sexo/gênero oposto ao seu (LOURO, 2009, p. 89).

Conforme esclarece Weeks (2000), a suposição essencialista consiste em uma das vertentes mais fortes de explicação sobre a sexualidade, inclusive nos tempos atuais. Tal pressuposto é válido quando levamos em conta os discursos do senso comum, haja vista, por exemplo, o argumento de Maria Rita, que não consegue admitir outra forma de prazer além da heterossexual, afinal, ao aprender, durante toda sua vida, que essa é a orientação certa, ela só consegue visualizar a homossexualidade como um 
defeito, ou melhor, como algo falho diante da normalidade e da legitimidade da prática heterossexual.

Há de se concordar que, quando menciona o possível sofrimento referente à homossexualidade, ela não está completamente equivocada. É compreensível não desejar filhos(as) gays perante uma sociedade homofóbica, isto é, que trata com ódio, preconceito e violência indivíduos que se relacionam sexualmente com pessoas do mesmo sexo. No entanto, como diz Weeks, é preciso admitir também que a sociedade, devido a mudanças na configuração da família e do casamento, ao controle das taxas de natalidade, à legalização do aborto em alguns países e a uma efetiva ação dos movimentos sociais - entre estes, o Feminista e o LGBT (Lésbicas, Gays, Bissexuais, Travestis e Transexuais) -, vem olhando de forma menos autoritária para a sexualidade, reconhecendo, inclusive, as diversidades sexuais (WEEKS, 2000). Em virtude dessas mudanças:

Cada vez mais, a homossexualidade se torna uma opção, ou uma escolha, a qual os indivíduos podem seguir de um modo que era impossível numa sociedade mais hierárquica e monolítica. A existência de um modo de vida gay dá oportunidade para as pessoas explorarem suas necessidades e desejos, sob formas que eram algumas vezes literalmente inimagináveis até bem pouco tempo. É por isso, obviamente, que a homossexualidade é vista, frequentemente, como uma ameaça para aqueles ligados ao status quo moral, estejam eles situados à esquerda ou à direita do espectro social (WEEKS, 2000, p. 70).

O projeto elaborado por Maria Rita foi denominado Sexualidade humana e tinha como propósito promover o reconhecimento da diversidade de valores, crenças e comportamentos relativos à sexualidade, bem como o conhecimento do próprio corpo. A ideia dessa professora era primeiro propor discussões sobre a sexualidade e o gênero como construções culturais, para então desmistificar preconceitos e, em seguida, introduzir orientações preventivas quanto à pratica do sexo. A proposta mencionava a utilização de filmes, mas não especificava quais, tampouco como se dariam as discussões com as crianças. Assim como Gislaine, Helena, Bianca e Carla, Maria Rita não desenvolveu o projeto apresentado como avaliação final do curso. Na verdade, ela afirma não se lembrar da atividade e nem de tê-la colocado em prática. 
A professora argumenta, porém, que foi relevante ter participado do GDE, pois o curso lhe proporcionou pensar que é preciso olhar para o outro e também aceitá-lo: "Como que eu falo? Vai te pontuando. Ele vai te dando uma direção, um rumo para você ver que as coisas mudaram, que não são mais assim" (Entrevista, 16 jun. 2014). Como exemplo de mudança nesse sentido, ela menciona a família como uma das instituições que vem se transformando ao longo do tempo, modificação esta que inevitavelmente chega à escola. Assim, Maria Rita aponta a mudança de pensamento em relação à diversidade sexual como sendo fundamental para aqueles(as) que trabalham na educação:

Por exemplo, hoje nós temos muito caso em escola, eu também já tive enquanto professora, da criança chegar, ele tem duas mães, ele não tem um pai e uma mãe, ou ele tem dois pais [...]. Às vezes, a criança fala: "Ah, eu tenho duas mães". Então, as professoras comentam, falam que não tem problema, que está tudo certo e aí já muda o assunto. Porque nós estamos no século XXI, não é, Ana? E já tem que começar a mudar mesmo esse pensamento, porque nós não temos mais esse modelo de família que a gente preconiza (Entrevista, 16 jun. 2014).

Todavia, ela destaca que, mais do que qualquer aprendizagem efetuada durante o GDE, o exercício de se colocar no lugar do outro é a ação mais importante para gerar a mudança de pensamento:

O curso é um bom direcionamento? É. Ele ajuda? Ajuda. Mas não só o curso. Não adianta, isso aí já é mentir, é uma ilusão. Não é só o curso, eu acho que ele é um norte, que ele te pontua, que ele te direciona, assim, para você abrir os olhos. Mas, também, você pode muito bem terminar o curso e fechar os olhos, se você não quer mudar. Só a pessoa faz a mudança nela, não é o curso, é quando ela entende que ela precisa mudar e que o mundo não é daquele jeito, se colocar no lugar do outro. Você está entendendo? (Entrevista, 16 jun. 2014).

A história de vida de Maria Rita evidenciou uma mulher que não se resignou ao poder patriarcal, vivenciado desde quando era apenas filha. Ela resistiu ao cativeiro da esposa-mãe e saiu para o mundo, tornando-se independente. Desse modo, por mais que tenha se casado e se tornado mãe, ela não perdeu a autonomia sobre si, como mulher.

Essa professora também alcançou o lugar por ela desejado na docência, visto que sempre foi considerada excelente profissional e há pouco tempo alcançou uma 
progressão na carreira, assumindo a direção de uma escola. Devido a isso, Maria Rita se vê como uma profissional de sucesso no magistério.

Em sua atuação como professora, quanto em sua passagem pelo GDE, notei resquícios de uma feminilidade patriarcal e resistências no que diz respeito à diversidade sexual e de gênero. Todavia, é possível perceber que Maria Rita, principalmente no que se refere à sua honesta fala sobre a homossexualidade, está claramente em um processo de reflexão sobre o que sente e o que percebe ao seu redor.

Em outras palavras, em sua socialização como mulher e em sua prática como professora, o lidar com a diversidade sexual e de gênero ainda é algo desconhecido, o que, por sua vez, lhe provoca questionamentos, mas também muita reflexividade.

$\mathrm{Na}$ construção do perfil das seis entrevistadas, pude notar influências de suas percepções sobre ser mulher em suas concepções sobre ser professora, bem como um movimento de contestação e de reprodução das imposições da sociedade patriarcal. Assim, pode-se dizer que, ao participarem do GDE e conhecerem a perspectiva histórico-sociocultural da sexualidade e das relações de gênero, essas docentes estranharam, questionaram, sentiram indignação acerca daquilo que até então desconheciam, ao mesmo tempo em que resistiram e evidenciaram as dificuldades práticas de uma educação questionadora dos estereótipos e preconceitos quanto à sexualidade e ao gênero.

Tendo isso em vista, proponho, a seguir, algumas reflexões sobre os limites, mas também sobre as possibilidades que foram engendradas em uma formação docente que priorizou a discussão e a valorização da diversidade sexual e de gênero no âmbito da escola. 


\title{
CONSIDERAÇÕES FINAIS: O GDE, AS MULHERES-PROFESSORAS, OS LIMITES E AS POSSIBILIDADES
}

\author{
Há esperanças que é uma loucura ter. Pois eu \\ digo-te que se não fossem essas já eu teria \\ desistido da vida \\ JOSÉ SARAMAGO \\ (Ensaio sobre a cegueira)
}

Ao iniciar esta pesquisa, minha hipótese era a de que o curso Gênero e Diversidade na Escola (GDE) poderia, sim, exercer forte influência nas percepções das participantes sobre o que é ser mulher e ser professora em nossa sociedade. Lá no começo desta minha jornada de pesquisa, tal hipótese carregava uma esperança, quase uma aposta na vida feminina para além do patriarcado. Chego ao final desta tese ciente da loucura daquela afirmação quando desvinculada do contexto atual. Entretanto, mesmo sabendo dos limites de tal esperança, posso hoje afirmar algumas possibilidades reais de contribuição da política de formação docente em gênero e diversidade aqui examinada.

Os registros da participação das professoras Gislaine, Celina, Helena, Bianca, Carla e Maria Rita na plataforma Moodle, bem como seus relatos durante as entrevistas, evidenciam os múltiplos sentidos de ser mulher. A beleza e a vaidade enaltecidas por Gislaine e Carla; a força presente em todas, mas ressaltada por Maria Rita; a maternidade valorizada por Bianca; e o acúmulo de tarefas, alvo da crítica de Helena: todos esses aspectos descrevem o que pode ser, para elas, uma mulher. Também há o ciúme expresso por pais, irmãos e parceiros, bem como a violência que assola a existência feminina, traços mais fortemente presentes nas falas de Gislaine, Helena, Carla e Maria Rita.

Entretanto, ser mulher, para elas, não se reduz a ser vítima de si mesma, de seus pais e/ou parceiros ou até mesmo da sociedade. Seus discursos demonstram resistências ao poder patriarcal, uma vez que não aceitam todos os atributos sociais que são fixados às mulheres. Pelo contrário, elas contestam e questionam - como fazem Helena, Bianca e Maria Rita -, criando estratégias para subverter as normas -, a exemplo de Gislaine, sobre conciliar a vida de esposa, mãe e professora. Tal resistência aos imperativos 
patriarcais, por sua vez, quebra a ideia de um único modo de ser mulher, atribuindo múltiplos sentidos a essa categoria. E é justamente nesse contexto que podemos perceber a historicidade e, portanto, a pluralidade que marcam os sentidos sociais e culturais do que nossa sociedade denomina mulher, para além do sexo biológico que ela carrega (RÍOS, 2005).

Contudo, se por um lado as entrevistadas resistem aos mandos e desmandos da sociedade machista, por outro, elas também reproduzem os preceitos e os preconceitos da masculinidade, ao deixarem prevalecer a feminilidade patriarcal em suas percepções e posicionamentos (PISANO, 2004). Essa reprodução se manifesta, por exemplo, quando Maria Rita e Carla falam da homossexualidade em suas famílias, legitimando a heteronormatividade a partir da justificativa de que outra orientação sexual pode causar sofrimento ao sujeito. Já Celina, tendo como referência os estereótipos sociais femininos da delicadeza, da pureza e da passividade, recrimina determinadas atitudes de algumas mulheres, concluindo que elas "não se dão ao respeito". Uma lógica semelhante de pensamento triunfa nas percepções de Bianca, Carla e Maria Rita, que se assustam com a precocidade sexual das crianças na escola - mas, principalmente, no caso das meninas -, ou então no depoimento de Gislaine, que contesta o feminismo por associá-lo à falta de feminilidade e por entendê-lo como uma versão invertida do machismo.

Quando se enredam na reprodução da feminilidade patriarcal, Gislaine, Celina, Helena, Bianca, Carla e Maria Rita tornam-se prisioneiras da maternidade e da conjugalidade presentes no patriarcado (RÍOS, 2005). Todavia, em outros momentos, elas próprias observam o peso dessa reprodução, como quando Helena e Bianca questionam a dupla jornada de trabalho feminino, ou quando Maria Rita contesta a autoridade do pai e busca livrar-se de tal controle. É nesse âmbito, de oscilação e tensão entre a reprodução e a resistência, que essas professoras foram e vão se construindo enquanto mulheres.

Suas concepções sobre ser professora também vêm acopladas às características socialmente atribuídas à sua condição de mulher: dedicação, doação e sofrimento. Ainda que para Celina, Carla, Bianca e Maria Rita o magistério não tenha sido a primeira opção de carreira - o que contradiz a ideia de professora nata defendida por Gislaine -, elas acabam se identificando àquelas características. Nesse cenário, o uso da 
categoria gênero nos ajuda a compreender a interferência de nossa socialização como homens ou mulheres na escolha de nossa profissão e em nossa atuação profissional, dado que "as mulheres passam a ser geralmente associadas às atividades como alimentação, maternidade, cuidado e educação. Enquanto que os homens são costumeiramente vistos como provedores e relacionados ao uso do poder" (VIANNA, 2002, p. 53).

Logo, algumas referências femininas são relacionadas à docência sem muitos questionamentos. É o caso, por exemplo, do uso da palavra dom e da percepção de que para lecionar é preciso gostar de crianças, como argumenta Gislaine; das memórias infantis de Carla, que reforçam certo essencialismo feminino à profissão docente quando ela diz que sempre gostou de brincar de escolinha; da satisfação de Bianca ao ser reconhecida como mãe de um de seus(as) alunos(as); ou de quando valorizam a renúncia do(a) professor(a) em nome do bem-estar dos(as) alunos(as), conforme a fala de Maria Rita.

Em contrapartida, elas também destacam o papel da(o) professora(o) como uma mediadora entre o(a) aluno(a) e o conhecimento, como sugerem Helena, Carla e Celina. Esta última reforça, porém, a dificuldade de concretização de tal tarefa quando a escola carrega para si funções que, até então, eram de responsabilidade da família. A concepção de que a(o) professora(o) é um(a) mediador(a) no processo de ensino e aprendizagem confirma, por sua vez, o entendimento de que determinadas funções não são de responsabilidade da escola, mas da instância familiar.

Do mesmo modo como as diferentes formas de ser mulher oscilam entre reproduções e resistências à cultura patriarcal, as diferentes formas de ser professora equilibra-se entre o papel da segunda mãe e o de especialista de um determinado conhecimento. Por conseguinte, a atividade docente é regada pela paixão pelo ato de lecionar - justificativa de Gislaine, Bianca e Maria Rita para a permanência na docência -, mas também pelo desencanto, marca forte no discurso de Celina.

Em relação à participação dessas mulheres-professoras no GDE, pude perceber que, em um primeiro momento, ela se deveu mais às possibilidades de ascensão em uma profissão desvalorizada, já que cursá-lo lhes conferiu pontos na carreira docente, o que resultava em vantagens na escolha de aulas e até mesmo em aumento salarial. Não 
obstante, com o desenrolar do curso, as professoras admitem que passaram a se interessar pelas temáticas de sexualidade e relações de gênero, assuntos até então desconhecidos, mas presentes no local onde lecionavam ou ainda lecionam. Nesse contexto, o GDE se apresenta como um curso inovador.

A partir da apresentação da perspectiva histórico-sociocultural da sexualidade e das relações de gênero, as professoras foram levadas a confrontar sua própria visão essencialista sobre esses temas. O confronto se deu na forma de um estranhamento, como demonstra Gislaine em relação ao feminismo; na vontade de se aprofundar e pesquisar sobre o assunto, interesse demonstrado por Celina; no questionamento perante o pesado fardo de ser mulher e na indignação diante da situação da mulher, como destacam Bianca e Carla ao mencionarem os Escritos Milenares. Participar do GDE, portanto, proporcionou certa desnaturalização acerca da condição feminina.

Consequentemente, tais movimentos trouxeram reflexões, uma vez que entender o caráter social da construção das relações de gênero proporcionou uma visão mais ampla sobre a atuação de mulheres e homens na sociedade. É a partir da aprendizagem sobre gênero e, no módulo seguinte, sobre sexualidade na perspectiva histórica, que essas professoras conseguem admitir a necessidade de se respeitar a diversidade sexual (fala de Gislaine ao relatar sua relação com uma prima lésbica) e a importância de reconhecer as mudanças como parte inevitável do processo sócio-histórico (como frisou Maria Rita ao falar sobre a necessidade de os(as) professores(as) se atualizarem quanto às modificações que ocorrem em instâncias tradicionais, como a família).

No âmbito da instituição escolar, as professoras afirmam a presença da sexualidade e das relações de gênero nas escolas em que atuam. Citam também suas intervenções, quando necessárias, nos episódios que envolvem questões sexuais e de gênero, destacando a contribuição do GDE em sua formação docente. Entretanto, não deixam de mencionar os obstáculos para efetuar um trabalho a respeito desses temas em sala de aula.

As interferências do GDE na concepção sobre ser professora evidenciam-se, por exemplo, quando Helena indaga quanto à segregação do masculino e do feminino, afirmando que, após fazer o curso, passou a questionar o hábito de fazer fila para meninos e fila para meninas. Ou quando Gislaine reconhece, em sua própria atuação 
profissional, que foi reprodutora de preconceitos e desigualdades de gênero em sala de aula. Ademais, entendo que a identificação da presença da sexualidade, do gênero e da diversidade na escola, bem como o reconhecimento de que é preciso respeitar as diferenças, como destacam Celina, Bianca, Carla e Maria Rita, sejam também uma forma de contribuição do GDE à prática pedagógica dessas professoras.

Em relação à não identificação, penso que o ocultamento ou até mesmo o descaso a respeito da presença da diversidade sexual e de gênero na escola relatados por essas professoras ao se referirem a momentos anteriores à participação no GDE revelam aquilo que Guacira Lopes Louro (2000b) chama de invisibilidade da norma, o que leva, por sua vez, à aceitação de uma única verdade. Isso se dá porque "a norma não precisa dizer sobre si; ela é identidade suposta, presumida, e isto a torna, de algum modo, praticamente invisível" (LOURO, 2000b, p. 99). Assim, a participação no curso proporcionou, de certa forma, estranhamento e desconfiança acerca do que até então era considerado concebível, aceito e normal no contexto escolar.

O estranhamento e certa resistência ao tema ainda são notáveis em muitas de nossas escolas, conforme evidenciam os inúmeros obstáculos relatados pelas professoras entrevistadas para a efetivação do que aprenderam durante o GDE. A forma como a família e a equipe escolar podem encarar essa intervenção é alvo de uma preocupação demonstrada, por exemplo, no relato de Carla. Já Celina admite ter vergonha de falar sobre sexualidade em público. Bianca, por sua vez, atribui ao fato de ser o sexo um tabu as resistências para abordar o assunto na escola. Consequentemente, tais entraves impedem a elaboração de uma intervenção crítica, cedendo lugar à ideia de que a sexualidade é um problema e um assunto restrito à área das ciências naturais e da saúde, visto que remente à prevenção da gravidez e de doenças sexualmente transmissíveis (DSTs), posicionamento defendido por Carla quando diz que os temas se encaixam melhor nas aulas de Biologia.

Essas justificativas remetem à noção de que a sexualidade é um assunto privado e pessoal, e que, portanto, trabalhar com esse tema na escola seria contradizer valores aprendidos na família e na religião. Tal concepção reforça o medo e a insegurança das professoras para lidar pedagogicamente com a diversidade, o que desvaloriza a percepção da sexualidade e do gênero como questões sociais, culturais e políticas, 
minando qualquer possibilidade de desconstrução de preconceitos relativos a essas temáticas.

Vale lembrar que a percepção moralista envolvendo as questões sexuais e de gênero é tão forte nos dias atuais em nossa sociedade, que dá margem ao surgimento de projetos de lei como o Escola Sem Partido (193/2016). De acordo com o referido programa, qualquer questionamento sobre a perspectiva biologizante e essencialista da sexualidade e das relações de gênero - o que também recebe o nome de ideologia de gênero no texto do projeto - deveria ser proibido no âmbito escolar. Ao impedir a discussão da diversidade sexual e de gênero da escola, tal projeto reforça a lógica patriarcal e heteronormativa existente no interior da instituição, retira toda a autonomia e a liberdade de expressão do professorado em sala de aula, bem como reduz o papel da escola à função de única e exclusivamente transmitir conteúdos.

É preciso reconhecer que, em virtude de seus processos de socialização no que concerne às diferentes formas de ser mulher e dos obstáculos relatados pelas professoras quanto ao trabalho sobre sexualidade e relações de gênero na escola, as resistências ao que aprenderam durante o GDE eram, de certa forma, previsíveis. Isso porque estamos tratando de possíveis modificações que um curso de apenas 200 horas pode proporcionar a pessoas que aprenderam, durante toda a vida, a serem mulheres de acordo com os moldes aceitos em uma sociedade patriarcal e machista. Portanto, faz-se necessário considerar que a construção de um olhar crítico sobre a sexualidade e sua relação com as diferentes formas de ser mulher consiste em um processo longo e não linear, o que implica até mesmo a relativização do propósito de questionar estereótipos, preconceitos e desigualdades sexuais e de gênero em um curso breve e a distância.

Além disso, outro aspecto a se levar em conta em um curso como o GDE referese ao formato de uma educação a distância. Como explica Fabiana Marques Costa (2011), o uso da educação a distância para a formação de professores(as) é um dos pressupostos da UNESCO. A autora assinala que a UNESCO vê na Educação a Distância uma "maneira eficaz de oferecer formação continuada a professores durante o seu tempo de serviço. Além disso, recomenda-se que professores se tornem proficientes no uso da EaD” (COSTA, 2011, s/p). Do mesmo modo, o décimo capítulo do Plano Nacional de Educação (BRASIL, 1998), intitulado Educação a distância e tecnologias 
educacionais, certifica a importância de se desenvolver um paradigma para tal modalidade de ensino.

A relação da EaD com as Tecnologias de Comunicação e Informação (TIC) é também problematizada por Marilene Proença Rebello de Souza e Denise Trento Rebello de Souza (2008), que fizeram uma revisão da literatura acadêmica canadense e norte-americana sobre EaD. Entre os prós e os contras do uso dessa modalidade, elas constataram a defesa do caráter democrático dessa forma de educação, visto que a acessibilidade e a flexibilidade são muito positivas para o processo de aprendizagem.

Com base em tal literatura, as autoras examinam o caso brasileiro, mais especificamente o Programa de Educação Continuada (PEC) ${ }^{29}$ realizado no Estado de São Paulo. Com edições nos anos de 2001 e 2002, o referido programa tinha como objetivo licenciar professores(as) em serviço em nível superior. Dessa análise, o que chama a atenção é o espantoso número de professores(as) formados(as) em um espaço de tempo relativamente curto:

Com duração de apenas 18 meses, turmas de 40 professores em média, em três turnos (manhã, tarde e noite), este primeiro esforço de oferecimento de formação em nível superior graduou 6.233 professores efetivos (1610 receberam a titulação pela USP). Apenas como comparação, na Faculdade de Educação da USP ingressam em suas 3 turmas de alunos anualmente 160 alunos. Para graduar o mesmo número de alunos seriam necessários, em situação de fluxo contínuo e sem evasão, mais de 13 anos! (SOUZA; SOUZA, 2008, p. 75).

Nesse contexto, assim como os estudos internacionais propõem mais aprofundamento no que tange à EaD e ao uso das TIC, Souza e Souza (2008) também reiteram a necessidade de investigações em relação ao caso brasileiro, visto que é

\footnotetext{
${ }^{29}$ O Programa de Educação Continuada (PEC) surgiu da parceria entre a União Nacional dos Dirigentes de Ensino (UNDIME), a Fundação para o Desenvolvimento da Educação (FDE), a Fundação Carlos Alberto Vanzolini (FCAV), a Universidade de São Paulo (USP) e a Pontifícia Universidade Católica de São Paulo (PUC-SP). A finalidade do programa era propiciar formação em nível superior para professores(as) em serviço. O PEC teve duas edições, sendo estas realizadas em 2001 e 2002. A primeira edição contou com a participação da Universidade Estadual Paulista (UNESP) e foi chamada de PEC Estadual, pois foi oferecida aos(às) professores(as) efetivos de $1^{\mathrm{a}}$ a $4^{\mathrm{a}}$ série da Rede Estadual de Ensino do Estado de São Paulo. Já a segunda edição foi denominada PEC Municípios, uma vez que o programa foi estendido também aos(às) professores(as) da Rede Municipal do Estado de São Paulo (SOUZA; SOUZA, 2008; BUENO; SOUZA, 2012).
} 
preciso mais informações acerca da apropriação e da construção do conhecimento em relação à atividade docente. As autoras argumentam:

Os levantamentos realizados no Canadá e nos Estados Unidos da América demonstram a necessidade deste aprofundamento também no Brasil, que utiliza há mais de quarenta anos os instrumentos e a instrução a distância. Além disso, do ponto de vista da democratização do ensino e da qualidade do ensino oferecido temos ainda muitas questões a responder e dentre elas: quais serão as repercussões desta modalidade de formação na prática docente? Que contribuições esta modalidade trará para a melhoria da qualidade do ensino? (SOUZA; SOUZA, 2008, p. 77).

Em outro estudo, Denise Trento Rebello de Souza, agora em coautoria com Belmira Oliveira Bueno (2012), faz uma análise crítica da formação de professores(as) que se processa pelo uso da $\mathrm{EaD}$ e das TIC. Ao explorarem e examinarem novamente as edições do PEC, as autoras verificam, nesse modelo de aprendizagem, a predominância da ideia de que a qualidade de ensino é determinada pelo nível da formação docente e a existência de uma lógica de quase-mercado, pois "o Estado opera de modo similar às instituições privadas" e "contribui com a disseminação de valores empresariais e mercantis, como os de produtividade e competição" (BUENO; SOUZA, 2012, p. 170171). Em vista disso, elas apontam:

A ênfase sobre a formação docente, que possibilita a existência do referido mercado, é justificada por ao menos duas lógicas discursivas: uma que ressalta a centralidade dos professores nas sociedades contemporâneas, marcadas por mudanças diversas e aceleradas (tecnológicas, sociais, econômicas); outra que relaciona a (baixa) qualidade dos sistemas públicos de ensino à (baixa) qualidade na formação docente. Essa segunda linha argumentativa assume especial destaque no cenário educacional brasileiro, atuando como importante dispositivo para a sustentação do mercado de formação de professores. Mercado entendido, também, como mercado simbólico, onde circulam bens simbólicos, e que não funciona inteiramente em torno da maximização do lucro monetário (BUENO; SOUZA, 2012, p. 171172).

É a partir da constituição de um quadro de quase-mercado da formação docente que Denise Trento Rebello de Souza (2006) observa a existência do argumento da incompetência, termo cunhado pela autora a partir de seus estudos sobre os programas educacionais efetivados entre 1982 e 1994. Em outras palavras, o argumento da 
incompetência admite a presença, tanto no âmbito das políticas e da literatura sobre educação, quando no quadro de funcionários que compõem a escola, de um discurso que atribui aos(às) professores(as) a culpa por um sistema educacional fraco. Conforme explica Souza (2006, p. 484):

\begin{abstract}
Identificamos, nesse sentido, a presença de um argumento que vem sendo utilizado para sustentar a crescente importância atribuída à formação continuada de professores no interior de um projeto de melhoria da qualidade da escola. Trata-se do argumento da incompetência, cujo cerne afirma que a principal causa para a baixa qualidade do sistema educacional é, justamente, a incompetência dos professores. Em função de sua má-formação inicial, os professores não saberiam como lidar com a diversidade de alunos presentes nas escolas hoje, especialmente aqueles das camadas populares. Consequentemente, seguindo essa linha de raciocínio, a única, ou a principal ação a ser perseguida para melhorar a qualidade do sistema educacional, seria melhorar a competência dos professores.
\end{abstract}

Em tal contexto, também se estabelece a ideia de que a melhoria da formação docente culmina na melhoria do sistema educacional. Porém, os entraves ao estabelecimento de uma aprendizagem que possa contribuir para a atividade docente não parecem ser tão simples a ponto de pensarmos que, ao inserirmos mais conhecimentos na formação de professores(as), consequentemente teremos resultados positivos no que concerne à qualidade da educação.

Logo, nessa lógica de mercado voltada à formação de professores(as), as “medidas propostas insistem nos sistemas de ‘acreditação' (no caso da formação inicial) e nas lógicas de avaliação (no caso formação continuada), arrastando uma concepção escolarizada da formação de professores" (NÓVOA, 1999, p. 14). Ainda na perspectiva de António Nóvoa (1999), a consolidação desse mercado de formação leva por terra a reflexão sobre a própria experiência docente, ao que acrescento a necessária revisão dos valores arcaicos, patriarcais e machistas que marcam essa experiência.

Tendo isso em vista, considero interessante a forma como José Mario Pires Azanha (2004) discute a temática da formação docente. Segundo o autor, pensar a questão educacional como a aplicação de um determinado saber teórico a uma determinada situação é, no mínimo, problemático. Azanha (2004) argumenta que essa formulação se torna discutível, uma vez que não dá para pensar, por exemplo, a formação do(a) professor(a) apartada das experiências e dos valores que acompanham o 
próprio processo de formação. Ele menciona como exemplo a educação sexual, a qual, em seu entender, “jamais poderá ser conduzida a partir apenas de informações sobre desenvolvimento e fisiologia do sexo" (AZANHA, 2004, p. 370).

Isso implica dizer que a melhoria da formação docente está para além da lógica de aquisição de mais conhecimentos, uma vez que tal formação envolve valores e contextos distintos. Além disso, é preciso também apontar alguns aspectos que precisam ainda ser pensados e revisados sobre os cursos que visam auxiliar o(a) professor(a) ao longo de seu desenvolvimento profissional docente. É nessa perspectiva que retomo as reflexões de Vera Maria Ferrão Candau (1996, p. 149) sobre a formação docente, a partir dos três eixos propostos por ela: “considerar a escola como lócus fundamental da formação continuada, valorizar o saber docente e reconhecer o ciclo de vida profissional dos professores".

Destes, irei aqui me concentrar apenas em dois, a saber, a escola como lócus de formação docente e o ciclo de vida profissional dos(as) professores(as). Considero que tais aspectos são importantes para explicar alguns limites - os quais também apontam possibilidades - para a efetivação das aprendizagens adquiridas durante o GDE. Já sobre a valorização do saber docente, penso que ela ocorreu no desenvolvimento do curso, visto que mesmo que o conhecimento sobre a diversidade sexual e de gênero tenha sido apresentado por pesquisadores(as) da área, as educadoras foram levadas a falar de suas experiências e estas, por sua vez, foram discutidas e pensadas coletivamente. Nesse sentido, os fóruns de discussão consistiram em um momento importante de troca de informações e saberes entre as cursistas e os(as) profissionais envolvidos(as) no curso.

Todavia, a ideia da escola como lócus de formação em que o(a) professor(a) "aprende, desaprende, reestrutura o aprendizado, faz descobertas e, portanto, é nesse lócus que muitas vezes ele vai aprimorando sua formação" (CANDAU, 1996, p. 144), não recebeu sua devida atenção durante a formação docente proposta pelo GDE. Isso talvez ajude a explicar por que as professoras tiveram dificuldades em aplicar, em suas escolas, aquilo que aprenderam durante o curso. Para além dos motivos que envolvem os processos de socialização, o GDE não envolveu as escolas em que tais docentes trabalham, mas somente alguns sujeitos em particular, ou seja, somente os(as) docentes 
que se sentiram motivados(as), por algum motivo, a fazerem o curso. Muitas vezes, essas professoras foram as únicas de suas escolas a participarem do GDE.

É possível afirmar, assim, que as dificuldades das professoras quanto à aplicação do que foi aprendido durante o GDE, bem como a resistência da escola em trabalhar com os temas sexualidade e relações de gênero, tenham relação com o não envolvimento da equipe escolar a que as professoras pertencem durante a formação proporcionada pelo curso. Nesse sentido, explica Liane Kelen Rizzato (2013, p. 257258):

Incitar a reflexão sobre diversidade e manter todo um sistema, uma organização e uma cultura de equipe de trabalho docente que não contribuem para que haja condições de mudança na prática educativa, é o mesmo que repetir intenções incapazes de gerar ações concretas. O trabalho pela inclusão da diversidade na escola precisa estar presente no projeto político pedagógico de cada instituição, ser discutido por toda a equipe e comunidade escolar e, efetivamente, permear as ações cotidianas de todos e de todas.

Outro ponto a destacar para pensar o GDE é relativo ao ciclo de vida profissional dos(as) professores(as). Com base no estudo de Huberman, Candau (1996) destaca a importância de se considerarem os distintos momentos da carreira docente, reconhecendo-os como um processo heterogêneo. A partir dessa perspectiva, a autora afirma que a formação docente engloba várias nuances, pois as necessidades, os problemas e as buscas são diferentes para os distintos grupos de professores(as): os(as) que estão no estágio inicial; os(as) que estão em um momento de estabilidade profissional, ou diante de questionamentos a respeito de sua carreira; e os(as) que se encontram na etapa final, a aposentadoria.

No caso do GDE, não levar em consideração a complexidade acerca dos ciclos de vida profissional das professoras pesou tanto na não aplicação do projeto elaborado ao final do curso, como também na importância dada por cada docente ao trabalho com esses temas na escola. As seis entrevistadas encontravam-se em diferentes momentos da carreira docente durante o curso, apesar de algumas delas possuírem tempos de serviço próximos.

Gislaine, Celina, Bianca e Maria Rita, por exemplo, estavam há mais de 20 anos na docência e já em vias de se aposentarem; contudo, enquanto Gislaine, Bianca e 
Maria Rita demonstravam satisfação pelo magistério, a desvalorização docente ecoava desânimo e angústia no discurso de Celina. As quatro professoras demonstraram interesse quanto às temáticas ligadas à sexualidade e às relações de gênero, o que foi perceptível em suas participações na plataforma Moodle e também em seus relatos nas entrevistas. Em contrapartida, mesmo desmotivada com a carreira docente, Celina foi a única professora que aplicou em sua escola o projeto elaborado durante o curso.

Helena e Carla, ambas com mais de 10 anos de carreira, possuíam perspectivas parecidas quanto à condição de ser professora, visto que destacavam a importância do(a) professor(a) no processo de ensino-aprendizagem do(a) aluno(a). Porém, Helena via na atividade docente possibilidades de questionar estereótipos e desigualdades referentes à diversidade sexual e de gênero, enquanto Carla preferia não se pronunciar sobre essas temáticas, deixando tal tarefa a cargo do(a) professor(a) de Biologia. Essas comparações nos mostram, assim, que tanto os distintos ciclos de vida profissional quanto às distintas percepções em torno das diferentes formas de ser professora influíram na efetivação do GDE na prática docente.

Candau (1996, p. 150) afirma que esses eixos consistem em aspectos relevantes para se pensar uma formação docente que priorize a "reflexividade crítica sobre as práticas e de (re)construção permanente de uma identidade pessoal e profissional, em interação mútua". Por outro lado, é preciso levar em conta que talvez o formato atual do GDE não suportasse a consideração dos dois eixos que destaquei em prática, o que necessitaria de renovações em sua estrutura.

É nesse âmbito, portanto, que podemos finalizar a reflexão sobre a formação que foi oferecida aos(às) professores(as) via o GDE. Já foi dito, em momentos anteriores desta tese, que a desconstrução de valores tradicionais no que tange à sexualidade e às relações de gênero não se dá de uma hora para a outra. Em qualquer aposta de política pública educacional que vise questionar preconceitos relativos à questão sexual e de gênero, é preciso lembrar, pois, da força dos processos de socialização.

De fato, um curso de aperfeiçoamento ou de extensão não seria suficiente para causar uma revolução nas formas de pensar, ser e de agir dessas mulheres e, tenho certeza, de que de tantas outras. A vivência no curso GDE agregou novos elementos 
de reflexividade, mas talvez não o suficiente para romper com o que vivenciam em outros espaços de sociabilidade. As rupturas nunca serão imediatas e definitivas.

Nós mesmas vivemos cotidianamente um processo de reflexividade, de confronto com nossas crenças e valores, que mesmo quando revistos e compreendidos, não nos livram de contradições em nosso agir. Essa é a dor e a delícia do processo de construção de novas consciências e de mudanças de atitudes e de comportamentos.

Não há como negar que o GDE potencializou esse processo de reflexividade, ainda que não se reflita fortemente numa nova práxis. Isso se dá, pois, ao agregar novo elementos de reflexividade, o curso problematizou socializações referentes à sexualidade e ao gênero, o que, de certa forma, incomodou e provocou estranhamento nas educadoras selecionadas para participar desta pesquisa. Por conseguinte, tais docentes sentiram-se indignadas e foram levadas a indagar suas atuações como mulheres e também como professoras.

Entretanto, a brevidade do curso não pode ser descartada, uma vez que apostar em uma formação de 200 horas como forma de sanar a discriminação e o preconceito referentes à sexualidade e às relações de gênero é, no mínimo, arriscado. Como já mencionado, quando falamos dessas temáticas, estamos nos referindo a aprendizagens culturais que marcam e segregam profundamente homens e mulheres. Contudo, vejo nesses limites o início de algumas possibilidades, afinal, é justamente por meio dos entraves e das dificuldades que podemos pensar em estratégias e alternativas para a construção e a efetivação de políticas públicas de educação para a diversidade sexual e de gênero.

Destaco, ainda, que embora o propósito do GDE tenha sido contribuir para o questionamento acerca da diversidade sexual e de gênero no campo da formação docente, é necessário levar em conta que tal iniciativa não é a única, nem a principal maneira de problematizar relações de gênero, sexualidade e docência. Embora o GDE foi relevante para repensar as diferentes formas de ser mulher, é necessário considerar que uma mudança pessoal/individual não basta (e não basta mesmo), se não houver acolhimento e respaldo institucional, ou seja da escola, da gestão e dos(as) demais colegas de profissão. 
Assim, é preciso olhar para o curso aqui em pauta como uma formação que gerou um espaço de discussões, questionamentos, estranhamentos e desconfianças acerca da sexualidade e das relações de gênero, o que, por sua vez, se estendeu tanto ao âmbito pessoal - as diferentes formas de ser mulher -, quanto ao âmbito profissional as diferentes formas de ser professora. Faz-se necessário considerar, além disso, que a proposta nos forneceu experiências, evidenciando limites e possibilidades (e esperanças, por que não?) de uma política pública educacional que objetivou a desconstrução dos estereótipos e dos preconceitos referentes à diversidade sexual e de gênero. 


\section{REFERÊNCIAS}

ALVES, Lynn. Um olhar pedagógico das interfaces do Moodle. In: ALVES, Lynn; BARROS, Daniela; OKADA, Alexandre (Orgs.). Moodle: estratégias pedagógicas e estudos de caso. Salvador: Edunet, 2009. p. 187-207.

ANDRÉ, Marli. Formação de professores: a constituição de um campo de estudos. Educação, Porto Alegre, v. 33, n. 3, p. 174-181, set./dez. 2010.

APPLE, Michel W. Trabalho docente e textos: economia política das relações de classe e de gênero em educação. Porto Alegre: Artes Médicas, 1995.

ASSUMPÇÃO, Andreia dos Santos Barreto Monsores de. Educação para a igualdade na perspectiva de gênero. 2012. 154f. Dissertação (Mestrado em Bens Culturais e Projetos Sociais) - Fundação Getúlio Vargas, Centro de Pesquisa e Documentação de História Contemporânea do Brasil, Rio de Janeiro, 2012.

BARDIN, Laurence. Análise de conteúdo. Lisboa: Edições 70, 1977.

BEAUVOIR, Simone. O segundo sexo: 2. A experiência vivida. Tradução de Sergio Milliet. 3. ed. Rio de Janeiro: Nova Fronteira, 1980.

BEZERRA, Giovani Ferreira; ARAUJO, Doracina Aparecida de Castro. Novas (re)configurações no Ministério da Educação: entre o fio de Ariadne e a mortalha de Penélope. Revista Brasileira de Educação, v. 19, n. 56, p. 101-122, jan./mar. 2014.

BOFF, Leonardo. A águia e a galinha: uma metáfora da condição humana. 16. ed. Petrópolis: Vozes, 1998,

BOGDAN, Robert; BIKLEN, Sari. Investigação qualitativa em educação: uma introdução à teoria e aos métodos. Tradução de Maria João Alvarez, Sara Bahia dos Santos e Telmo Murinho Baptista. Portugal: Porto, 1994.

BRASIL. Ministério da Educação. Plano Nacional de Educação. Brasília: INEP, 1998.

BRASIL. Ministério da Saúde. Conselho Nacional de Combate à Discriminação. Brasil Sem Homofobia: programa de combate à violência e à discriminação contra GLBT e promoção da cidadania homossexual. Brasília: Ministério da Saúde, 2004.

BRASIL. Ministério da Educação. Secretaria de Educação Continuada, Alfabetização e Diversidade. Gênero e diversidade sexual na escola: reconhecer diferenças e superar preconceitos. Brasília: Secad/MEC, 2007. 
BRITZMAN, Deborah. Curiosidade, sexualidade e currículo. In: LOURO, Guacira Lopes. (Org.). O corpo educado: pedagogias da sexualidade. Belo Horizonte: Ed. Autêntica, 2000, p. 83-111.

BUENO, Belmira Oliveira; SOUZA, Denise Trento Rebello de. Pedagogia contemporânea e formação de professores em serviço: lógicas e dispositivos de um modelo em expansão. In: BITTAR, Marisa et al. (Orgs.). Pesquisa em educação no Brasil: balanços e perspectivas. São Carlos: EdUFSCar, 2012. p. 161-182.

BUTLER, Judith. Variações sobre sexo e gênero: Beauvoir, Witting e Foucault. In: BENHABIB, Leyla; CORNELL, Drucilla (Orgs.). Feminismo como critica da modernidade. Tradução de Nathanael da Costa Caixeiro. Rio de Janeiro: Rosa dos Tempos, 1987. p. 139-154.

CANDAU, Vera Maria Ferrão. Formação continuada de professores: tendências atuais. In: REALI, Aline Maria M. R; MIZUKAMI, Maria da Graça (Orgs.). Formação de professores: tendências atuais. São Carlos: EDUFSCar, 1996. p. 139-152.

CARRARA, Sérgio et al. Gênero e diversidade na escola: trajetórias e repercussões de uma política pública inovadora. Rio de Janeiro: CEPESC, 2011.

CARVALHO, Marília Pinto de. Gênero e trabalho docente: em busca de um referencial teórico. In: BRUSCHINI, Cristina; HOLLANDA, Heloísa Buarque (Orgs.). Horizontes plurais: novos estudos de gênero no Brasil. São Paulo: Editora 34; Fundação Carlos Chagas, 1998. p. 379-409.

. No coração da sala de aula: gênero e trabalho docente nas séries iniciais. São Paulo: Xamã, 1999.

Gênero: para que serve esse conceito na prática pedagógica? In: SOARES, Leôncio Soares et al. (Orgs.). Convergências e tensões no campo da formação e do trabalho docente. Belo Horizonte: Autêntica, 2010. p. 512-525.

. O conceito de gênero: uma leitura com base nos trabalhos do GT Sociologia da Educação da ANPed (1999-2000). Revista Brasileira de Educação, v. 16, n. 46, p. 99117, jan./abr. 2011.

CASTELLS, Manuel. A era da informação: economia, sociedade e cultura. Volume II: O poder da identidade. Tradução de Klauss Brandini Gerhardt. São Paulo: Paz e Terra, 1999.

CERQUEIRA, Rosilene Souza Gomes de. Educação em sexualidade na escola: entre a normalização e a perspectiva dos direitos humanos. Dissertação (Mestrado em Saúde Coletiva) - Universidade do Estado do Rio de Janeiro, Rio de Janeiro, 2012. 
COLE, Babette. Cabelinhos nuns lugares engraçados. Tradução de Lenice Bueno da Silva. São Paulo: Ática, 1999.

COSTA, Ana Paula. As concepções de sexualidade de um grupo de alunas do curso de Pedagogia: uma análise a partir do recorte de gênero. 2009. 136f. Dissertação (Mestrado em Educação Escolar) - Universidade Estadual Paulista, Faculdade de Ciências e Letras, Araraquara, 2009.

COSTA, Ana Paula; RIBEIRO, Paulo Rennes Marçal. Como se produz mulheres "recatadas" e "prendadas"? Alguns questionamentos sobre sexualidade e relações de gênero. In: RIBEIRO, Paulo Rennes Marçal (Org.). Gênero, sexualidade e educação sexual em debate. São Paulo: Cultura Acadêmica, 2009. p. 33-44.

COSTA, Fabiana Maria. Conceitos sobre educação a distância: suas implicações. Publicação avulsa: notas de aula do curso "Formação de formadores: orientação pedagógica em Educação a Distância e plataforma Moodle”. Rio Claro: CECEMCA/UNESP, Pró-Reitoria de Extensão Universitária, 2011.

COSTA, Fabiana Maria; LIMA, Maria Teresa; ROSSI, Célia Regina. Formação de tutores: orientações pedagógicas em Educação a Distancia - informações básicas sobre organização das atividades de ensino e aprendizagem. Versão 1. Publicação avulsa. Rio Claro: UNESP, Pró-Reitoria de Extensão Universitária, 2009.

DIRETORIA DE ENSINO - REGIÃO DE SÃO JOSÉ DO RIO PRETO. São José do Rio Preto: Secretaria da Educação do Estado de São Paulo, 2013. Disponível em: <http://desjriopreto.edunet.sp.gov.br/>. Acesso em: 13 jul. 2013.

EGGERT, Edla. O feminismo ou os feminismos: uma leitura das produções teóricas. Cadernos IHU Ideias (UNISINOS), São Leopoldo, v. 1, n. 2, p. 1-7, 2003.

Narrar processos: tramas da violência doméstica e possibilidades para a educação. Florianópolis: Ed. Mulheres, 2009.

ELIAS, Norbert. O processo civilizador. V. 1: Uma história dos costumes. Revisão e apresentação de Renato Janine Ribeiro. Rio de Janeiro: Jorge Zahar, 1994.

FOUCAULT, Michel. História da sexualidade I: a vontade de saber. Tradução de Maria Thereza da Costa Albuquerque e J. A Guilhon Albuquerque. Rio de Janeiro: Graal, 1985.

. Microfísica do poder. Organização e tradução de Roberto Machado. 15. ed. Rio de Janeiro: Graal, 2000. 
FRANCO, Maria Laura Puglisi Barbosa. Análise de conteúdo. 3. ed. Brasília: Liber Livros, 2008.

FURLANI, Jimena. Direitos humanos, direitos sexuais e pedagogia queer: o que essas abordagens têm a dizer à educação sexual. In: JUNQUEIRA, Rogério Diniz (Org.). Diversidade sexual na educação: problematizações sobre a homofobia nas escolas. Brasília: Ministério da Educação, Secad, UNESCO, 2009. p. 293-323.

GARCIA, Osmar Arruda. Marcas da experiência docente na formação docente em gênero e diversidade sexual, um olhar sobre o curso "Gênero e Diversidade na Escola" (GDE). 2015. 162f. Dissertação (Mestrado em Sociologia da Educação) Universidade de São Paulo, Faculdade de Educação, São Paulo, 2015.

GATTI, Bernardete Angelina. A construção da pesquisa em educação no Brasil. Brasília: Plano, 2002.

GÊNERO E DIVERSIDADE NA ESCOLA (GDE/UNESP). Resultados. Disponível em: <https://sites.google.com/site/gdeunesp/>. Acesso em: 20 mar. 2012.

GOVERNO DO ESTADO DE SÃO PAULO. Caracterização socioeconômica das regiões do estado de São Paulo - Região administrativa de São José do Rio Preto. São Paulo: Secretaria de Planejamento e Desenvolvimento Regional, 2012. Disponível em: <http://www.planejamento.sp.gov.br/noti_anexo/files/uam/trabalhos/SJ\%20Rio\%20Pret o.pdf>. Acesso em: 2 jul. 2013.

GRIGOROWITSCHS, Tamara. O conceito "socialização" caiu em desuso? Uma análise dos processos de socialização na infância com base em Georg Simmel e Georg H. Mead. Educação e Sociedade, Campinas, v. 29, n. 102, p. 33-54, jan./abr. 2008.

GRÖSZ, Dirce Margarete. Representações de gênero no cotidiano de professores e professoras. 2008. 154f. Dissertação (Mestrado em Políticas Públicas e Gestão da Educação) - Universidade de Brasília, Faculdade de Educação, Brasília, 2008.

HEILBORN, Maria Luiza. Construção de si, gênero e sexualidade. In: HEILBORN, Maria Luiza (Org.). Sexualidade: o olhar das ciências sociais. Rio de Janeiro: Jorge Zahar, 1999. p. 40-58.

HOOKS, bell. Eros, erotismo e processo pedagógico. In: LOURO, Guacira Lopes (Org.). O corpo educado: pedagogias da sexualidade. 2. ed. Belo Horizonte: Autêntica, 2000. p. 113-123).

JULIA, Dominique. A cultura escolar como objeto histórico. Tradução de Gizele de Souza. Revista Brasileira de História da Educação, Campinas, n. 1, p. 9-43, jan./jun. 2001. 
JUNQUEIRA, Rogério Diniz. Educação e homofobia: o reconhecimento da diversidade sexual para além do multiculturalismo liberal. In: (Org.). Diversidade sexual na educação: problematizações sobre a homofobia nas escolas. Brasília: Ministério da Educação, Secad, UNESCO, 2009a. p. 367-444.

Introdução - Homofobia nas escolas: um problema de todos. In: (Org.).

Diversidade sexual na educação: problematizações sobre a homofobia nas escolas. Brasília: Ministério da Educação, Secad, UNESCO, 2009b. p. 13-51.

KINSEY - Vamos falar de sexo. Direção e roteiro: Bill Condon. 118 min. EUA, 2004.

LISPECTOR, Clarice. A maçã no escuro. Rio de Janeiro: Rocco, 1998.

LOURO, Guacira Lopes. Magistério de $1^{\circ}$ grau: um trabalho de mulher. Educação e Realidade, Porto Alegre, v. 14, n. 2, p. 31-39, 1989.

Pedagogias da sexualidade. In: (Org.). O corpo educado: pedagogias da sexualidade. 2. ed. Belo Horizonte: Autêntica, 2000a. p. 9-34.

Currículo, gênero e sexualidade. Lisboa: Porto Editora, 2000b.

Mulheres na sala de aula. In: DEL PRIORE, Mary (Org.). História das mulheres no Brasil. 5. ed. São Paulo: Contexto, 2001. p. 443-481.

Gênero, sexualidade e educação: uma perspectiva pós-estruturalista. Rio de Janeiro: Vozes, 2003.

. Heteronormatividade e homofobia. In: JUNQUEIRA, Rogério Diniz (Org.). Diversidade sexual na educação: problematizações sobre a homofobia nas escolas. Brasília: Ministério da Educação, Secad, UNESCO, 2009. p. 85-93.

LUDKE. Menga; ANDRÉ, Marli. Pesquisa em educação: abordagens qualitativas. São Paulo: EPU, 1986.

MARCELO, Carlos. Desenvolvimento profissional docente: passado e futuro. Sísifo, Sevilha (Espanha), n. 8, p. 7-22, jan./abr. 2009.

MARTINS, Heloísa Helena T. de Souza. Metodologia qualitativa de pesquisa. Educação e Pesquisa, São Paulo, v. 30, n. 2, p. 287-298, maio/ago. 2004.

MATOS, Marlise. Teorias de gênero ou teorias e gênero? Se e como os estudos de gênero e feministas se transformaram em um campo novo para as ciências sociais. Revista Estudos Feministas, Florianópolis, v. 16, n. 2, p. 333-357, maio/ago. 2008. 
MINAYO, Maria Cecília de Souza. O desafio do conhecimento: pesquisa qualitativa em saúde. São Paulo: Hucitec; Rio de Janeiro: Abrasco, 2000.

MOSTAFA, Maria. Professores na encruzilhada entre o público e o privado: o curso Gênero e Diversidade na Escola. 2009. 125f. Dissertação (Mestrado em Ciências Humanas e Saúde) - Universidade do Estado do Rio de Janeiro, Instituto de Medicina Social, Rio de Janeiro, 2009.

NICHOLSON, Linda. Interpretando o gênero. Revista Estudos Feministas, Florianópolis, v. 8, n. 2, p. 9-41, 2000.

NÓVOA, António. Os professores na virada do milênio: do excesso dos discursos à pobreza das práticas. Educação e Pesquisa, São Paulo, v. 25, n. 1, p. 11-20, jan./jun.1999.

NUNES, Ednalva Macedo. Gênero e diversidade na escola: limites e possibilidades na formação de professores/as. 2015. 153f. Dissertação (Mestrado em Psicologia) Pontifícia Universidade Católica de Goiás, Goiânia, 2015.

OLIVEIRA, Núcia Alexandra Silva de. Discutindo gênero e beleza. Esboços: Revista do Programa de Pós-graduação em História da UFSC, Santa Catarina, v. 8, n. 8, p. 173-183, 2000.

Imagens de beleza... questões de gênero. Caderno Espaço Feminino, Santa Catarina, v. 17, n. 1, p. 293-316, jan./jul. 2007.

PEREIRA, Maria Elizabete et al. (Orgs.). Gênero e diversidade na escola: formação de professores em gênero, sexualidade, orientação sexual e relações étnico-raciais. Brasília, Rio de Janeiro: SPM, 2007.

PEREIRA, Maria Elizabete; BRANDT, Maria Elisa. A efetivação de parcerias necessárias à construção de uma política de educação em gênero e diversidade. In: PEREIRA, Maria Eizabeth et al. (Orgs.). Gênero e diversidade na escola: formação de professores em gênero, sexualidade, orientação sexual e relações étnico-raciais. Brasília, Rio de Janeiro: SPM, 2007. p. 19-23.

PEREIRA, Zilene Moreira. Sexualidade e gênero na pesquisa e na prática de ensino em biociências e saúde. 2014. 201f. Tese (Doutorado em Ensino em Biociências e Saúde) - Instituto Oswaldo Cruz, Rio de Janeiro, 2014.

PISANO, Margarita. EI triunfo de la masculinidade. México: Fem-e-libros: 2004.

PRADO, Adélia. Bagagem. São Paulo: Siciliano, 1993. 
PREFEITURA MUNICIPAL DE SÃO JOSÉ DO RIO PRETO. Plano Municipal pela Educação 2005/2010. São José do Rio Preto: 2005. Disponível em: <http://www.riopreto.sp.gov.br/educacao/arquivos/downloads/plano_municipal_da_edu cacao.pdf. Acesso em 8 jul. 2013.

QUARTIERO, Eliana Teresinha. Longe demais das capitais: distâncias e desigualdades. 2014. 202f. Tese (Doutorado em Políticas Públicas, Saúde, Trabalho e Produção de Subjetividade) - Universidade Federal do Rio Grande do Sul, Instituto de Psicologia, Porto Alegre, 2014.

RIBEIRO, Paulo Rennes Marçal. Educação sexual além da informação. São Paulo: E.P.U, 1990.

Os momentos históricos da educação sexual no Brasil. In: (Org.). Sexualidade e educação: aproximações necessárias. São Paulo: Arte \& Ciência, 2004. p. $15-25$.

RÍOS, Marcela Lagarde y de los. Los cautiverios de las mujeres: madresposas, monjas, putas, presas y locas. México: Universidad Nacional Autónoma de México, 2005 .

RIZZATO, Liane Kellen. Percepções de professores/as sobre gênero, sexualidade e homofobia: pensando a formação continuada a partir de relatos da prática docente. 2013. Dissertação (Mestrado em Educação) - Faculdade de Educação, Universidade de São Paulo, São Paulo, 2013.

ROBLES, Martha. Mulheres, mitos e deusas: o feminino através dos tempos. Tradução de William Lagos e Débora Dutra Vieira. São Paulo: Aleph, 2006.

ROCHA, Ruth. Faca sem ponta, galinha sem pé. Ática: São Paulo, 1999.

ROSSI, Célia Regina et al. Gênero e diversidade na escola: reflexões acerca da formação continuada sobre assuntos da diversidade sexual. Revista Contexto \& Educação, v. 27, p. 6-34, 2012.

RUIZ, Alice. Ladainha. In: ESPÍNDOLA, Alzira; RUIZ, Alice. Paralelas. Rio de Janeiro: Duncan Discos, 2005.

SAMPAIO, Maria das Dores. Política pública educacional como promotora do reconhecimento da diversidade: análise do curso Gênero e Diversidade na Escola. 2014. 157f. Dissertação (Mestrado em Ciência Política) - Centro Universitário Euro Americana, Brasília, 2014. 
SARAMAGO, José. Ensaio sobre a cegueira. São Paulo: Companhia das Letras, 1995.

SCAVONE, Lucilla. Estudos de gênero: uma sociologia feminista? Revista Estudos Feministas, Florianópolis, v. 16, n. 1, p. 173-186, jan./abr. 2008.

SCOTT, Joan Wallace. Gênero: uma categoria útil de análise histórica. Tradução: Guacira Lopes Louro. Educação e Realidade, Porto Alegre, v. 20, n. 2, p. 71-99, jul./dez. 1995.

SECOS \& MOLHADOS. Angústia. In: Secos \& Molhados. São Paulo: Continental, 1974.

SEFFNER, Fernando. Equívocos e armadilhas na articulação entre diversidade sexual e políticas de inclusão escolar. In: JUNQUEIRA, Rogério Diniz (Org.). Diversidade sexual na educação: problematizações sobre a homofobia nas escolas. Brasília: Ministério da Educação, Secad, UNESCO, 2009. p. 125-139.

SILVA, Leandro Veloso. Inflexões de aprendizagem em gênero, sexualidade etnia na formação de docentes em EAD. 2013. 187f. Dissertação (Mestrado em Formação de Professores) - Universidade Federal de Lavras, Faculdade de Educação, Lavras, 2013.

SILVA, Sirlene Mota Pinheiro da. Decifra-me! Não me devore! Gênero e sexualidade nas tramas das lembranças e nas práticas escolares. 2015. 333f. Tese (Doutorado em Didática, Teorias de Ensino e Práticas Escolares) - Universidade de São Paulo, Faculdade de Educação, São Paulo, 2015.

SILVA, Tomaz Tadeu da. Documentos de identidade: uma introdução às teorias do currículo. 2. ed. Belo Horizonte: Autêntica, 2001.

SIMMEL, Georg. Questões fundamentais da sociologia: indivíduo e sociedade. Tradução de Pedro Caldas. Rio de Janeiro: Jorge Zahar, 2006.

SOUZA, Denise Trento Rebello de. Formação continuada de professores e fracasso escolar: problematizando o argumento da incompetência. Educação e Pesquisa, São Paulo, v. 32, n. 3, p. 477-492, set./dez. 2006.

SOUZA, Fabiana Cristina de. Meninos e meninas na escola: um encontro possível? Porto Alegre: Zouk, 2006.

SOUZA, Marilene Proença Rebello de; SOUZA, Denise Trento Rebello de. Novas tecnologias de comunicação e informação: o que dizem as revisões acadêmicas canadenses, norte americanas e a experiência brasileira? ETD - Educação Temática Digital, Campinas, v. 9, n. 2, p. 61-79, jun. 2008. 
SUPLICY, Marta. De Mariazinha a Maria. Rio de Janeiro: Vozes, 1985.

TEIXEIRA, Fabiane Lopes. Gênero e Diversidade na Escola - GDE: investigando narrativas de profissionais da educação sobre diversidade sexual e de gênero no espaço escolar. 2014. 153f. Tese (Doutorado em Educação) - Universidade Federal de Pelotas, Faculdade de Educação, Pelotas, 2014.

VALENTE, Luís; MOREIRA, Paulo; DIAS, Paulo. Moodle: moda, mania ou inovação? In: ALVES, Lynn; BARROS, Daniela; OKADA, Alexandre (Orgs.). Moodle: estratégias pedagógicas e estudos de caso. Salvador: Edunet, 2009. p. 35-54.

VÁZQUEZ, Adolfo Sánchez. Ética. Tradução de João Dell'Anna. Rio de Janeiro: Civilização Brasileira, 1985.

VIANNA, Cláudia. Entre o desencanto e a paixão: desafio para o magistério. In: BRUSCHINI, Cristina; HOLLANDA, Heloísa Buarque (Orgs.). Horizontes plurais: novos estudos de gênero no Brasil. Fundação Carlos Chagas. São Paulo: Editora 34, 1998. p. 315-342.

. O sexo e o gênero da docência. Cadernos Pagu, Campinas, n. 17/18, p. 81$103,2001 / 2002$.

Contribuições do conceito de gênero para a análise da feminização do magistério no Brasil. In: CAMPOS, Maria Christina Siqueira de Souza; SILVA, Vera Lúcia Gaspar da (Orgs.). Feminização do magistério: vestígios do passado que marcam o presente. Bragança Paulista: EDUSF, 2002. p. 39-67.

Estudos de gênero, sexualidade e políticas públicas de educação: das ações coletivas aos planos e programas federais. 2011. 253f. Tese (Livre-Docência em Gênero e Educação) - Universidade de São Paulo, Faculdade de Educação, São Paulo, 2011.

Gênero, sexualidade e políticas públicas de educação: um diálogo com a produção acadêmica. Pro-posições, Campinas, v. 23, n. 2, p. 127-143, maio/ago. 2012.

A feminização do magistério na educação básica e os desafios para a prática e a identidade coletiva docente. In: YANNOULAS, Sílvia. Cristina (Coord.). Trabalhadoras: análise da feminização das profissões e ocupações. Brasília: Editorial Abaré, 2013. p. 159-180.

VIEIRA, Jacqueline Virmond. Produção de saber e poder sobre a sexualidade: análise crítica dos relatórios Kinsey, Master \& Jonhson e Hite. Revista Estudos Feministas, Florianópolis, v. 22, n. 2, p. 694-696, ago. 2014. 
WEEKS, Jeffrey. O corpo e a sexualidade. In: LOURO, Guacira Lopes (Org.). O corpo educado: pedagogias da sexualidade. 3. ed. Belo Horizonte: Autêntica, 2000. p. 35-82.

WHITAKER, Dulce. Homem \& mulher: o mito da desigualdade. São Paulo: Moderna, 1988.

WOLF, Naomi. O mito da beleza. Tradução de Wáldea Barcellos. Rio de Janeiro: Rocco, 1992. 
APÊNDICES 


\section{Apêndice A}

\section{Roteiro para a entrevista semiestruturada}

- Nome:

- Idade:

- Formação acadêmica:

- Nível de ensino em que atua:

- Data de realização da entrevista:

- Local:

- Horário de início da entrevista:

- Horário de término da entrevista:

1. Trajetória pessoal: Onde nasceu? Como foi sua infância? Como foi sua adolescência? Onde estudou? Como era quando aluna? Qual é seu estado civil? Tem filhos?

2. Trajetória profissional: $\mathrm{O}$ que a levou a ingressar no magistério? Onde você se formou? Há quanto tempo leciona? Como foi sua entrada no mercado de trabalho? Prosseguiu seus estudos em nível de aperfeiçoamento?

3. Atuação em sala de aula: Você já se deparou ou se depara com manifestações de sexualidade e relações de gênero em sala de aula/escola? O que sente diante dessas experiências? Tem alguma ação diante delas? Você poderia explicar?

4. Participação no GDE: Por que você participou do curso Gênero e Diversidade na Escola (GDE)? Poderia contar como foi participar do curso? Participar do curso contribuiu para sua atuação em sala de aula/escola? Você poderia explica?

5. Atuação em sala de aula após o GDE: O que você entende por sexualidade e relações de gênero? Houve ou não modificações em torno desses conceitos após sua participação no GDE? Você poderia explicar de que forma isso ocorreu? Após ou mesmo durante sua participação no GDE, suas ações e seus pensamentos referentes às manifestações de sexualidade e relações de gênero em sala de aula/escola sofreram ou não algum tipo de modificação? Você poderia explicar?

6. Significados: Para você, o que é ser professora? Para você, o que é ser mulher? Esse entendimento recebeu ou não influências de sua participação no curso GDE? 


\section{Apêndice B}

\section{Modelo da Carta Convite \\ Curso Gênero e Diversidade na Escola (GDE)}

\section{Prezada Professora,}

Meu nome é Ana Paula Costa e sou professora da rede estadual e particular de ensino da cidade de Americana (SP). Atualmente, também sou aluna do curso de Doutorado da Faculdade de Educação da Universidade de São Paulo e desenvolvo a pesquisa Sexualidade e Gênero: a docência após o curso Gênero e Diversidade na Escola $(G D E)$, a qual tem por objetivo investigar as possíveis influências do referido curso na compreensão de um grupo de professoras do Ensino Fundamental, rede municipal da cidade de São José do Rio Preto (SP), sobre os significados do que é ser mulher e ser professora sob a ótica das relações de gênero. A pesquisa conta com a orientação da Profa. Dra. Cláudia Vianna.

Mediante uma busca sobre os(as) professores(as) que participaram do curso GDE no ano de 2009 na cidade de São José do Rio Preto, cheguei ao seu e-mail e venho por meio deste convidá-la a participar da pesquisa, concedendo-me uma entrevista. Ressalto que sua participação é muito valiosa e importante para essa investigação.

Asseguro-lhe de que seu relato será utilizado eticamente, priorizando seu anonimato em relação às imagem e declarações. Além disso, poderemos realizar a entrevista de acordo com sua disponibilidade, no horário e no local em que a senhora preferir. Garanto-lhe também que, caso seja de sua vontade, podemos interromper sua participação a qualquer momento.

Estou à disposição para qualquer esclarecimento através dos contatos (19) xxxxx-Xxxx / (19) xxxx-xxxx ou pelo endereço eletrônico anpfeminista@gmail.com.br. Para visualizar meu currículo na Plataforma Lattes, basta acessar: <http://lattes.cnpq.br/7859028151954222>.

Agradeço desde já e aguardo seu e-mail com um posicionamento.

Abraços!

Ana Paula Costa 


\section{Apêndice C}

\section{Termo de Consentimento Livre e Esclarecido}

O Termo de Consentimento Livre e Esclarecido refere-se à pesquisa Sexualidade e Gênero: a docência após o curso Gênero e Diversidade na Escola (GDE), desenvolvida pela pesquisadora Ana Paula Costa na Faculdade de Educação da Universidade de São Paulo, junto ao Programa de Pós-Graduação em Educação, nível Doutorado. A pesquisa aqui proposta tem por objetivo investigar as possíveis influências do curso Gênero e Diversidade na Escola (GDE) na compreensão de um grupo de professoras do Ensino Fundamental, rede municipal da cidade de São José do Rio Preto (SP), sobre os significados do que é ser mulher e ser professora sob a ótica das relações de gênero.

Eu,

participante do curso GDE no ano de 2009, fui convidada a participar desta pesquisa concedendo à pesquisadora uma entrevista na modalidade semiestruturada, que será realizada individualmente, sendo gravada e, posteriormente, transcrita e analisada.

Ciente de minha participação na pesquisa, fui assegurada pela pesquisadora de que meu relato será utilizado eticamente, priorizando meu anonimato, de forma que minha imagem e minhas declarações sejam respeitadas e não me causem nenhum dano ou prejuízo. Além disso, foi-me assegurado que posso interromper minha participação na pesquisa a qualquer momento.

Nome legível e assinatura

Este termo possui duas cópias: uma para a senhora e outra para a pesquisadora. Agradeço sua participação na pesquisa e estou à disposição para qualquer esclarecimento através dos contatos (19) xxxxx-Xxxx / (19) xxxx-Xxxx ou pelo endereço eletrônico: anpfeminista@gmail.com.br

Atenciosamente,

Ana Paula Costa. 
ANEXO 


\section{Transcrição do vídeo Escritos Milenares}

- Slide 1: “A mulher deve adorar o homem como a um deus. Toda manhã, por nove vezes consecutivas, deve ajoelhar-se aos pés do marido e, de braços cruzados, perguntar-lhe: Senhor, que desejais que eu faça?" Zaratustra (filósofo persa, século VII a.C.).

- Slide 2: "Todas as mulheres que seduzirem e levarem ao casamento os súditos de Sua Majestade mediante o uso de perfumes, pinturas, dentes postiços, perucas e recheio nos quadris, incorrem em delito de bruxaria e o casamento fica automaticamente anulado.” Constituição Nacional Inglesa (lei do século XVIII).

- Slide 3: "Mesmo que a conduta do marido seja censurável, mesmo que este se dê a outros amores, a mulher virtuosa deve reverenciá-lo como a um deus. Durante a infância, uma mulher deve depender de seu pai, ao se casar de seu marido, se este morrer, de seus filhos e se não os tiver, de seu soberano. Uma mulher nunca deve governar a si própria.” Leis de Manu (Livro Sagrado da Índia).

- Slide 4: "Quando um homem for repreendido em público por uma mulher, cabe-lhe o direito de derrubá-la com um soco, desferir-lhe um pontapé e quebrar-lhe o nariz para que assim, desfigurada, não se deixe ver, envergonhada de sua face. E é bem merecido, por dirigir-se ao homem com maldade de linguajar ousado.” Le Ménagier de Paris (Tratado de Conduta Moral e Costumes da França, século XIV).

- Slide 5: "As crianças, os idiotas, os lunáticos e as mulheres não podem e não têm capacidade para efetuar negócios.” Henrique VII (Rei da Inglaterra, chefe da Igreja Anglicana, século XVI).

- Slide 6: "Quando uma mulher tiver conduta desordenada e deixar de cumprir suas obrigações do lar, o marido pode submetê-la à escravidão. Esta servidão pode, inclusive, ser exercida na casa de um credor de seu marido e, durante o período em que durar, é lícito a ele (ao marido) contrair novo matrimônio." Código de Hamurabi 
(Constituição Nacional da Babilônia, outorgada pelo Rei Hamurábi, que a concebeu sob inspiração divina, século XVII a.C.).

- Slide 7: “Os homens são superiores às mulheres porque Alá outorgou-lhes a primazia sobre elas. Portanto, dai aos varões o dobro do que dai às mulheres. Os maridos que sofrerem desobediência de suas mulheres podem castigá-las: deixá-las sós em seus leitos, e até bater nelas. Não se legou ao homem maior calamidade que a mulher." Alcorão (livro sagrado dos muçulmanos, recitado por Alá a Maomé no século VI).

- Slide 8: "Que as mulheres estejam caladas nas igrejas, porque não lhes é permitido falar. Se quiserem ser instruídas sobre algum ponto, interroguem em casa os seus maridos." São Paulo (apóstolo cristão, 67 d.C.).

- Slide 9: “A natureza só faz mulheres quando não pode fazer homens. A mulher é, portanto, um homem inferior." Aristóteles (filósofo, guia intelectual e preceptor grego de Alexandre, o Grande, século IV a.C.).

- Slide 10: "O pior adorno que uma mulher pode querer usar é ser sábia." Lutero (Teólogo alemão, reformador protestante, século VXI).

- Slide 11: Por esses escritos vê-se quão árduo foi o caminho parra as mulheres chegarem aos dias de hoje em igualdade de condições com os homens. Infelizmente, em muitos países islâmicos, as mulheres continuam na mesma situação desses escritos milenares. 